\title{
Global Economies, Regulatory Failure, \& Loose Money: Lessons for Regulating the Finance Sector from Iceland's Financial Crisis
}

Andrew P. Morriss

Texas A\&M University (TAMU) - School of Law

Birgir T. Petursson

RSE - Centre for Social and Economic Research, Birgir@laekjargata.is

\section{Recommended Citation}

Andrew P. Morriss \& Birgir T. Petursson, Global Economies, Regulatory Failure, \& Loose Money: Lessons for Regulating the Finance Sector from Iceland's Financial Crisis, (2012).

Available at: https://scholarship.law.ua.edu/fac_working_papers/161 


\title{
THE UNIVERSITY OF ALABAMA SCHOOL OF LAW
}

Global Economies, Regulatory Failure, \& Loose Money: Lessons for Regulating the Finance Sector from Iceland's Financial Crisis

\author{
Birgir T. Petursson
}

Andrew P. Morriss

59 Alabama Law Review (forthcoming 2012)

This paper can be downloaded without charge from the Social Science Research Network Electronic Paper Collection: http://ssrn.com/abstract=2016295 


\title{
Global Economies, Regulatory Failure, \& Loose Money: Lessons for Regulating the Finance Sector from Iceland's Financial Crisis
}

\author{
Birgir T. Petursson \\ birgir@laekjargata.is \\ Partner, Laekjargata Lawfirm, Reykjavik, Iceland \\ Co-founder and director, Centre for Social and Economic Research, \\ Reykjavik, Iceland \\ Lecturer, Faculty of Business Administration, University of Iceland \\ Andrew P. Morriss \\ amorriss@law.ua.edu \\ D. Paul Jones, Jr. \& Charlene A. Jones Chairholder in Law \\ $\&$ Professor of Business \\ Research Scholar \\ Regulatory Studies Center, George Washington University
}

March 3, 2012 


\title{
Global Economies, Regulatory Failure, \& Loose Money: Lessons for Regulating the Finance Sector from Iceland's Financial Crisis
}

\author{
Birgir T. Petursson $^{*} \&$ Andrew P. Morriss ${ }^{* *}$
}

\begin{abstract}
Iceland was the first developed economy to fall into crisis in 2008, with the collapse of its banking sector, currency value, and economy. The collapse threw Iceland into a political crisis and provoked a serious international dispute between Iceland and Britain and the Netherlands over responsibility for the failed banks. Prior to 2008 Iceland had been treated as the poster child for deregulation; since 2008 it has been held up as the poster child for the dangers of financial liberalization. Neither is accurate. Rather, Iceland presents a cautionary tale about the inter-relationships between fiscal and monetary policy and regulatory measures. Excessive liquidity fostered by central banks around the world, expansionary fiscal policies in Iceland, and inadequate understanding of fundamental economic linkages created conditions under which capital flooded Iceland and overwhelmed its financial institutions. Regulatory failures at the EU and Icelandic levels meant regulatory measures such as central bank interventions and deposit insurance exacerbated problems rather than correcting them. This paper explores those relationships, uncovering connections made visible by both Iceland's relatively small size and the comprehensive parliamentary investigation into the crisis. It concludes that regulators need to
\end{abstract}

\footnotetext{
${ }^{*}$ Partner, Laekjargata Lawfirm, Reykjavik, Iceland \& Co-Founder and Director, Centre for Social and Economic Research, Reykjavik, Iceland; Cand. jur. , University of Iceland, 1998. The authors thank the University of Alabama School of Law, and Law and Economics and Business Law Programs at the University of Illinois College of Law for financial support that made their collaboration easier; Liberty Fund, Inc. and the Searle Center at Northwestern University facilitated the collaboration by assisting with Petursson's travel in the U.S. in 2009; the Regulatory Studies Program at George Washington University hosted us in 2011 and participants at a seminar there provided helpful comments, as did participants in the business law workshop at American University's Washington College of Law. Roger Meiners, Richard W. Rahn, and Timothy Ridley also provided helpful comments; and Matthew Brown (Illinois), Clifford Henson (Illinois) and Hunter Hill (Alabama) provided extraordinarily helpful research assistance. Stephanie Davidson and the staff at the University of Illinois Law Library provided exceptional support in the initial research and with keeping up with events in 2009 and 2010 while Morriss was on the faculty there; staff at the University of Alabama provided equally excellent support in 2011. Students in Morriss' seminars on the financial crisis at the University of Alabama School of Law provided valuable insights through classroom discussions.

${ }^{* *}$ D. Paul Jones, Jr. \& Charlene A. Jones Chairholder in Law and Professor of Business, University of Alabama; Research Scholar, Regulatory Studies Center, George Washington University; Senior Scholar at the Mercatus Center at George Mason University, and Senior Fellow, Property \& Environment Research Center, Bozeman, Montana. A.B. Princeton University; J.D., M.Pub.Aff., University of Texas; Ph.D. (Economics) Massachusetts Institute of Technology.
} 


\section{focus attention on enhancing market-feedback mechanisms rather than on attempting to steer economies if they are to avoid "the next Iceland."}

Beginning in 1990, a series of economic reforms in Iceland transformed its economy from stagnant and statist to thriving and free. ${ }^{1}$ By 2004 , the Icelandic economy appeared as strong as any in the world, Iceland was widely touted as an example of how a small open economy could succeed, ${ }^{2}$ and Iceland was the sixth wealthiest country in the world as measured by GDP per capita. ${ }^{3}$ A new generation of Icelandic businessmen and bankers, sometimes colorfully referred to as "Viking raiders," were beginning to buy assets across Europe, including financial institutions in Scandinavia; real-estate in the Baltic; beverage production in Russia; telecom in eastern Europe; pharmaceuticals in the Mediterranean; and retail, food manufacturing and banking in the United Kingdom. ${ }^{4}$ The Icelandic currency (the krona or ISK) gained over $40 \%$ against the dollar, $30 \%$ against the yen, and $17 \%$ against the pound between the end of 2001 and the end of 2006, ${ }^{5}$ a performance all the more impressive considering that 1990 the krona was

\footnotetext{
${ }^{1}$ James McLean, Deregulation brings boom time to Iceland, THE TIMES (Nov. 29, 2007) available at http://business.timesonline.co.uk/tol/business/markets/europe/article2963336.ece ("the catalyst for a dramatic turna-round was the deregulation of the formerly state-controlled financial sector."); William Underhill, The Icemen Cometh, NewsweEK (May 23, 2005) available at http://www.newsweek.com/id/51773/page/1 ("Since the mid-'90s, the country's center-right government has pushed free-market reforms" producing an economy that "outstrips most of Europe"); Hannes H. Gissurarson, Miracle on Iceland, WALL ST. J. (January 29, 2004) available at http://courses.wcupa.edu/rbove/eco343/040Compecon/Scand/Iceland/040129prosper.htm ("after a radical and comprehensive course of liberalization that mirrors similar reforms in Thatcher's Britain, New Zealand and Chile, Iceland has emerged as one of the world's most prosperous countries.") See also, JAMES GWARTNEY AND ROBERT LAWSON ECONOMIC FREEDOM OF THE WORLD: 2009 ANNUAL REPORT 108 (2009) available at http://www.cato.org/pubs/efw/efw2009/efw2009-4.pdf (showing that Iceland's economic freedom score placed them $24^{\text {th }}$ in the world again by 2007); and JAMES GWARTNEY AND ROBERT LAWSON, ECONOMIC FREEDOM OF THE WORLD: 2006 ANNUAL REPORT 99 (2006), available at http://www.cato.org/pubs/efw/efw2006/efw2006-3-a-k.pdf (showing that Iceland's economic freedom score placed them $26^{\text {th }}$ in the world in $1990,17^{\text {th }}$ in $1995,12^{\text {th }}$ in 2000 , and $9^{\text {th }}$ in 2004).

${ }^{2}$ McLean, supra note 1 (noting that the IMD World Competitiveness Report rated Iceland the most competitive economy in Europe in 2004); Hannes Gissurarson and Daniel J. Mitchell, The Iceland Tax System - Key Features and Lessons for Policy Makers, VII ProsPeriTAS 1 (Issue V, August 2007).
}

${ }^{3}$ Iceland's GDP per capita on a purchasing power parity basis in 2004 was $\$ 34,117.756$, behind Luxembourg $(\$ 56,620.563)$, the United States $(\$ 39,771.787)$, Norway $(\$ 39,587.452)$, Ireland $(\$ 36,218.044)$ and Switzerland $(\$ 34,163.155)$. World Bank, WORLD DEVELOPMENT INDICATORS (2006). Iceland is, of course, a small economy in absolute terms - the total population was only 317,398 in 2010. World Bank, World Development Indicators (2010). For comparison, the least populated American state, Wyoming, has 563,626. U.S. Census, 2010 Resident Population Data (2010). http://2010.census.gov/2010census/data/apportionment-pop-text.php

${ }^{4}$ See Ian Griffiths, Next-Generation Viking Invasion, THE GUARDIAN (June 16, 2005) available at http://www.guardian.co.uk/business/2005/jun/16/marksspencer (describing "the appearance of a new breed of slick young Icelandic businessmen who have transformed the country's image from that of insular fisherman into one of a global entrepreneur"); Steve Hawkes, Jon Asgeir Johannesson: The rise and fall of a Viking raider who targeted high street, THE TIMES (October 16, 2008) (post-crash description of Icelandic financier as "Viking raider"); Roger Boyes, MELTDOWn ICELAND: LESSONS ON THE WORLD FINANCIAL CRISIS FROM A SMALL BANKRUPT ISLAND 2 (2009) (comparing executive jets of Icelandic businessmen to "the modern equivalent of the Viking longship").

${ }^{5}$ The Icelandic Central Bank's “midrate” exchange rates were 
worth less than $9 \%$ of what it had been worth in $1938 .{ }^{6}$ In 2003 , the OECD rated Iceland's pension fund system among the best in the world in contrast with the worrying status of the pensions of many of Iceland's European neighbors. ${ }^{7}$ Icelandic political leaders were being hailed for their economic policies ${ }^{8}$ and implementing sustainable resource management. ${ }^{9}$ In short, Iceland was a success, a poster child for deregulation, sustainability, and open economic policies. $^{10}$

\begin{tabular}{|l|l|l|l|l|}
\hline & U.S. Dollars & Japanese Yen & British Pounds & Euros \\
\hline Dec. 28, 2001 & 103.63 & 0.7885 & 150.05 & 91.44 \\
\hline Dec. 31, 2002 & 80.77 & 0.6805 & 130.09 & 84.71 \\
\hline Dec. 31, 2003 & 71.16 & 0.6656 & 126.69 & 89.76 \\
\hline Dec. 31, 2004 & 61.19 & 0.5969 & 118.15 & 83.51 \\
\hline Dec. 30, 2005 & 63.13 & 0.5376 & 108.85 & 74.7 \\
\hline Dec. 29, 2006 & 71.83 & 0.6043 & 140.98 & 94.61 \\
\hline Dec. 28, 2007 & 62.02 & 0.5499 & 123.99 & 91.18 \\
\hline Oct. 1, 2008 & 108.16 & 1.0198 & 192.97 & 153.05 \\
\hline Dec. 31, 2008 & 120.87 & 1.3398 & 175.43 & 169.97 \\
\hline
\end{tabular}

Statistics from Central Bank of Iceland, Exchange Rate, available at http://www.sedlabanki.is/?PageID=183.

${ }^{6}$ Gunnar Karlsson, THE HISTORY OF ICELAND 351 (2000).

${ }^{7}$ FinANCIAL AfFairs Division of the Directorate of FinANCIAL AND ENTERPRise AFFAirs of the OECD, 1 PENSION MARKETS IN FOCUS, June 2005 at 2-3 (noting that among OECD and selected non-OECD countries, only Switzerland and Iceland's pensions were funded in excess of 100\% of GDP for 2003, while Norway, Sweden, and Finland funded pensions at less than 10\% of GDP), and at 5 (noting that Iceland has the highest rate of pension fund assets to market capitalization among OECD countries), available at http://www.oecd.org/dataoecd/46/2/35063476.pdf.

${ }^{8}$ See Int'l Monetary Fund, Iceland: 2005 Article IV Consultation, Concluding Statement of the Mission (June 13, 2005), available at http://www.imf.org/external/np/ms/2005/061305.htm ("Overall, economic performance in Iceland has been impressive. The government should be commended for its consistent commitment to implementing and following policies that have laid a sound foundation for strong economic growth. These policies include structural reforms that have increased the economy's dynamism and flexibility, significant improvements in financial supervision, the introduction of a flexible exchange rate and inflation targeting, and a sustained period of sound fiscal management."); see generally Cod's Own Country, ECONOMIST, May 17, 2003 at 45 (praising Iceland's "remarkable economy" as it properly manages its marine and human resources and also diversifies and privatizes its industries).

${ }^{9}$ See e.g. Jonathan H. Adler, Free \& Green: a New Approach to Environmental Protection, 24 HARV. J.L. \& PuB. POL'Y 653, 686 (Spring 2001) (crediting the adoption of ITQs with the increased sustainability of fishing levels, as well as increases in "... the quality of the fish caught and the profitability of local fishing operations."); Save the Fish, THE WALl StreEt JouRnal, November 14, 2006, at A20 (crediting Iceland's adoption of ITQs with saving the fishing industry and reducing the strain between fishers and regulators). There are critics of the quota system as well. See Boyes, supra note 4, at 38-40 (criticizing quotas for creating property that was used to fund boom).

${ }^{10}$ See, e.g., Robert Wade, Iceland as Icarus, 52 ChALLENGE 5, 6 (May-June 2009) ("Neoliberals around the world hailed Iceland as vindication of free market principles."). 
Yet signs of trouble were visible as early as $2006,{ }^{11}$ although Icelandic authorities did not change course. By early 2008 it was apparent that the "miracle" had begun to unravel. ${ }^{12}$ As economic conditions deteriorated in Iceland and elsewhere, policymakers from Reykjavik to London made a series of policy errors that worsened the situation, turning what might have been limited to bankruptcy of two of the three major banks into the virtual bankruptcy of the entire economy. ${ }^{13}$ By October 1, 2008, Iceland's currency had lost all of its prior gains and more, falling well below its 2001 value against all major currencies; ${ }^{14}$ its three major banks had collapsed and been essentially nationalized; ${ }^{15}$ leading investors and businessmen were in or on the verge of bankruptcy; ${ }^{16}$ the United Kingdom had invoked anti-terrorism legislation to seize Icelandic assets there, ${ }^{17}$ the Icelandic government, politically isolated home and abroad, was being pressured to accept responsibility for ISK 340 billion in foreign depositors' accounts in the banks, a debt equivalent to $17 \%$ of GDP $;^{18}$ and the repayment obligation provoked a political crisis in Iceland that has continued into $2012 .{ }^{19}$ The narrative of the rewards of free market reforms was inverted and Iceland became the poster child for a much heavier hand in regulation of banking and international finance. ${ }^{20}$ Instead of the Icelandic policy makers who sparked the

${ }^{11}$ See, e.g. Moody's says worries about Iceland “exaggerated”, REUTERS NeWs, April 4, 2006 (claiming that Merrill Lynch and Danske Bank warned that banks were vulnerable due to, "the overheating economy, high inflation and overvalued crown ... [.]")

${ }^{12}$ See section II.E. infra.

${ }^{13}$ See notes 359 - 365 infra.

${ }^{14}$ See note 5 supra.

${ }^{15}$ See notes 351 - 359 infra.

${ }^{16}$ See section II.F. infra.

${ }^{17}$ [Landsbanki] 2001 Anti-Terrorism, Crime and Security Act, 2001, c. 24 [Singer \& Friedlander] Banking (Special Provisions) Act, 2008, c. 2. The specific orders made under those acts required separate (in)actions of the Parliament. See Landsbanki: from Heritable to Deposits Management (Heritable): http://www.opsi.gov.uk/si/si2008/uksi 20082644 en 1. From DM (H) to ING: http://www.opsi.gov.uk/si/si2008/uksi_20082666_en_1\#pt1-11g2. From Kaupthing Singer \& Friedlander to ING: http://www.opsi.gov.uk/si/si2008/uksi_20082674_en_1. The Treasury orders involved are available at 2001 AntiTerrorism, Crime and Security Act, 2001, c. 24; Banking (Special Provisions) Act, 2008, c. $2 \S \S 6,8,12$, \& 13(2). For the order transferring responsibility for accounts from Kaupthing Singer \& Friedlander to ING, see The Kaupthing Singer \& Friedlander Limited Transfer of Certain Rights and Liabilities Order 2008, S.I. 2008/2674 (U.K.). For the orders transferring responsibility for accounts from Landsbanki to ING, see The Heritable Bank plc Transfer of Certain Rights and Liabilities Order 2008, S.I. 2008/2644 (U.K.); see also, The Transfer of Rights and Liabilities to ING Order 2008, S.I. 2008/2644\\66 (U.K.).

${ }^{18}$ Direct Liabilities Estimated at 140\% of GDP, Landsbanki Daily Economic Briefing, July 20, 2009, available at http://www.landsbanki.is/english/markets/research/dailyeconomicbriefing?NewsID=14157.

${ }^{19}$ See notes 384 - 412 infra.

${ }^{20}$ Boyes, supra note 4, at ix (Iceland was "[t]he first major financial crisis of the global era"); Wade, supra note 10, at 32 ("The Iceland case shows that arrangements for cross-border banking supervision and deposit insurance need urgent strengthening. It has exposed loopholes in EU legislation about deposit insurance in the context of bank branches, bank subsidiaries, and online cross-border accounts. And by showing the dangers of mixing commercial and investment banking, it underlines the need to separate them (by reinstating Glass-Steagall, for example)."); Harold L. Sirkin, Warnings from Iceland, BusINESSWEEK ONLINE, October 14, 2009, available at http://www.businessweek.com/managing/content/oct2009/ca20091013_717732.htm ("The one thing about which most of us can now agree is that the pendulum swung too far in one direction. There was too little oversight."). 
boom being praised, they are now mocked for "a stunning collective madness" in daring to imagine that "a tiny fishing nation" could be "a global financial power." 21 A new Icelandic government, now led by the social-democratic Social Alliance (Icelandic: Samfylking) and the Left Green Movement initiated efforts to join the European Union, weaken the fisheries property rights system, and undo the economic reforms by instituting a sharply higher and progressive tax system and reregulating much of the economy. ${ }^{22}$

Neither the "Icelandic miracle" nor the "collective madness" accounts of Iceland's rise and fall are accurate. The "miracle" story does not include crucial policy failures and relationships among monetary and fiscal policies and financial markets, which ultimately undermined the initial gains from deregulation. Similarly, the "collective madness" story also ignores these failures and interconnections, instead putting the blame on markets generally and specifically on Icelandic financiers' lack of experience. Neither glib explanation pays sufficient attention to the vital role feedback plays in financial regulation. As we describe below, feedback from markets to regulators and from markets to financial actors is critical to avoiding financial crises. Unfortunately for Iceland, and the world, policymakers around the world dampened feedback mechanisms during the 1990s and 2000s and continue to do so today.

Getting the narrative wrong about Iceland's financial crisis has serious consequences not just for Icelanders, as perceptions of Iceland's crisis are shaping efforts by regulators ${ }^{23}$ around the world to assert more control over financial markets. ${ }^{24}$ If policy changes are adopted based on an incorrect understanding of the market forces and policy errors that led to the Icelandic crisis, the alleged reforms may simultaneously fail to forestall the "next Iceland" by failing to ensure that the same mistakes are not made again and deny other nations the advantages of the successful policies Iceland adopted in the 1990s.

While the financial crisis that swept through Iceland offers crucial lessons for other nations facing economic turmoil, the key lessons are ones not widely recognized. Its experiences were not peculiar to Iceland; there were policy decisions that are seen elsewhere today. Iceland's financial meltdown occurred before the world financial crisis, but as the global financial downturn continues the mistakes of the Icelandic crisis are in danger of being repeated in other small open economies and even in larger economies, such as the United States and United

\footnotetext{
${ }^{21}$ Michael Lewis, Wall Street on the Tundra, VANITY FAIR (April 2009) available at http://www.vanityfair.com/politics/features/2009/04/iceland200904.

${ }^{22}$ See notes 427 - 428 infra.

${ }^{23}$ When we refer to financial regulators we include central bank authorities acting on monetary policy. While these activities are often treated separately from the issuing of rules, inspection of banks, and so forth, a central theme in this Article is that the two are interrelated and so we adopt the shorter "regulators" in place of "regulators and central bank authorities".

${ }^{24}$ See generally, Boyes, supra note 4, and AsgeIR JONSSON, WHY ICELAND?: How ONE OF THE WORLD'S SMALLEST Countries Became the Meltdown's Biggest Casualty (2009). See also Willem H. Buiter \& Anne Sibert, The Icelandic banking crisis and what to do about it: The lender of last resort theory of optimal currency areas, CENTRE FOR ECONOMIC RESEARCH POLICY INSIGHT No. 26 (October 2008), available at http://www.cepr.org/pubs/PolicyInsights/PolicyInsight26.pdf; Douglas W. Arner \& Joseph J. Norton, Building a Framework to Address Failure of Complex Global Financial Institutions, 39 HoNG KoNG L. J. 95 at footnote 15 (claiming that the collapse of Icelandic financial institutions portends the collapse of financial institutions in Central Europe and Latin America.).
} 
Kingdom. ${ }^{25}$ Although attention at the moment is focused on southern European economies, the financial press has occasionally wondered whether the United Kingdom might be the "next Iceland."26 Moreover, Iceland's experience since the crisis offers practical experience about how to deal with financial crises, as the differential treatment of the three failed large banks reveals the advantages of a policy that addresses losses up front over a more politicized process of avoiding recognizing losses ex post.

In this Article, we argue that four sets of policy mistakes in Iceland escalated what might have been a relatively minor banking crisis into a systemic crisis that swamped Iceland's financial system. All four are relevant to understanding the current economic situation beyond Iceland.

First, after an overhaul of the Icelandic banking sector in the 1990s and the early 2000s, Icelandic banks took advantage of the strong ISK and high interest rates to transform themselves from banks servicing the local market into global financial powerhouses, making highly leveraged investments in assets outside Iceland. This transformation was made possible by dramatic increase in global liquidity brought about by central banks around the world. ${ }^{27}$ Financial regulators both in Iceland and elsewhere were caught off-guard by the impact of this increased liquidity, ${ }^{28}$ which transformed Iceland's deregulation of a primarily domestic banking industry into an event that ultimately had international significance. Although the focus on liquidity has diminished since the onset of the global financial crisis, its role in increasing risk remains poorly understood. Governments and central banks continue to ignore its implications for financial regulation as they pump extraordinary amounts of money into the world economy.

Second, Icelandic monetary policy authorities kept interest rates high, largely for domestic reasons ${ }^{29}$ but with the approval of international monetary authorities. ${ }^{30}$ Interest rates of

\footnotetext{
${ }^{25}$ Boyes, supra note 4, at x ("the questions raised by Icelanders about how to live in a globalized era, how to be the master of capital, not its servant, about finding one's own rhythm, are questions bothering us all.")

${ }^{26}$ See, e.g., Willem Buiter, How likely is a sterling crisis or: Is London really Reykjavik-on-Thames?, $\mathrm{ft.com} /$ maverecon (Nov. 13, 2008) available at http://blogs.ft.com/maverecon/2008/11/how-likely-is-a-sterlingcrisis-or-is-london-really-reykjavik-on-thames/\#more-359.

${ }^{27}$ See, e.g., A Working Model, THE ECONOMIST (April 11, 2005) (“central banks have created too much liquidity. Despite rising short-term interest rates in America, monetary policy is still unusually expansionary. Average shortterm rates in America, Europe and Japan have remained below nominal GDP growth for the longest period since the 1970s. In addition, America's loose policy has been amplified by the build-up in foreign-exchange reserves and domestic liquidity in countries that have tied their currencies to the dollar, notably China and the rest of Asia. As a result, over the past couple of years, global liquidity has expanded at its fastest pace for three decades.")

${ }^{28}$ See Central Bank of Iceland, The Central Bank's Assessment, 4 FinAnCiAl STABILITY at 3 (May 2008), available at http://www.sedlabanki.is/lisalib/getfile.aspx?itemid=6020 ("The 2007 annual accounts of Iceland's financial companies, particularly the three largest banks, show that they remain robust. Their capital position, profitability, and liquidity are sound, as is confirmed by the stress tests conducted by the Financial Supervisory Authority (FME) and the Central Bank."); Boris Agranovich, Was the Crash of an Icelandic Bank Icesave in the Netherlands Avoidable" EZINEARTICLES.COM, February 7, 2010, http://ezinearticles.com/?Was-the-Crash-of-an-Icelandic-BankIcesave-in-the-Netherlands-Avoidable?\&id=3714772 (claiming that the high swap rate for Icelandic banks in the market evidenced awareness of underlying liquidity troubles, but regulators did not take market behavior into account when analyzing liquidity risk).

${ }^{29}$ See, e.g., Central Bank of Iceland, Worse inflation outlook calls for a significantly tighter stance, 8(2) MONETARY BULLETIN 3-4 (July 2006) available at http://www.sedlabanki.is/lisalib/getfile.aspx?itemid=4131 (calling for higher interest rates in reaction to domestic inflation).
} 
$8-16 \%$ between 2001 and $2007,{ }^{31}$ a time when interest rates in large developed economies were extraordinarily low, ${ }^{32}$ drew enormous capital flows into Iceland. ${ }^{33}$ Because neither domestic financial regulators nor international monetary authorities used models that took into account such flows, ${ }^{34}$ Icelandic regulators took policy steps that exacerbated the Icelandic banks' problems rather than limiting them. Although the relatively small size of the Icelandic economy meant that even comparatively small capital flows had large impacts, financial regulators have not yet developed the methods to account for the impact of the "search for alpha" on financial institutions.

Third, the Icelandic government backed the expansion of the Icelandic banking sector post-privatization by implicitly guaranteeing the banks' accounts and investments, with the central bank serving as lender of last resort and political leaders giving assurances in foreign media to this end instead of explicitly rejecting such an idea. ${ }^{35}$ While pointing out the risk of the oversized Icelandic banking sector in proportion to the country's economy and its central bank reserves, international credit rating agencies nonetheless continued to provide favorable ratings for Icelandic banks ${ }^{36}$ because the debt of the tiny Icelandic government was extremely low. ${ }^{37}$ This enabled the Icelandic financial sector to expand its balance sheets through extensive borrowing, bringing the total liabilities of the financial sector up to ten times GDP, greatly

${ }^{30}$ See, e.g., OECD, Economic Survey of Iceland, 2006, POLICY BRIEF 4-5 (July 2006) ("the Central Bank needs to raise interest rates substantially so that inflation is brought back to the target. ... The Central Bank needs to reestablish the credibility of its commitment to the target through firmer policy and clearer communication."

${ }^{31}$ Central Bank of Iceland, Interest Rates - General Interest Rates, General Interest on Non-Indexed Loans, available at http://www.sedlabanki.is/?PageID=224.

${ }^{32}$ See John B. Taylor, The Financial Crisis and the Policy Responses: An Empirical Analysis of What Went Wrong (Nov. 2008) available at http://www.stanford.edu/ johntayl/FCPR.pdf (describing falling U.S. interest rates from 2000 to 2004 and low rates through 2006 and concluding that "actual interest rate decisions [by the Federal Reserve] fell well below what historical experience would suggest policy should be.”).

${ }^{33}$ See note 257 infra.

${ }^{34}$ Jonsson, supra note 24, at 68-71 (describing the policy of the Central Bank of Iceland: "Iceland then became ever more orthodox in its adherence to inflation-targeting policy, up to the point of being much more Catholic than the pope in viewing how the policy rate should be used to quell inflation. The economic department of CBI demanded rate hikes almost up to the moment the banks collapsed: no arguments, the country was going to bow to the books and hit the target." And further on the textbook models "all economic textbooks stated that a currency appreciation should cool down a small and open economy by pressing profits in the export sector and directing demand out of the country into imports. Never mind the uncomfortable evidence to the contrary that was becoming all too visible in Iceland by 2005.”)

${ }^{35}$ See Central Bank of Iceland, The Central Bank's Assessment, 4 FinANCIAL STABILITY at 3 (May 2008), available at http://www.sedlabanki.is/lisalib/getfile.aspx?itemid=6020 ("The 2007 annual accounts of Iceland's financial companies, particularly the three largest banks, show that they remain robust. Their capital position, profitability, and liquidity are sound, as is confirmed by the stress tests conducted by the Financial Supervisory Authority (FME) and the Central Bank."); Boris Agranovich, Was the Crash of an Icelandic Bank Icesave in the Netherlands Avoidable" EZINEARTICLES.COM, February 7, 2010, http://ezinearticles.com/?Was-the-Crash-of-an-Icelandic-Bank-

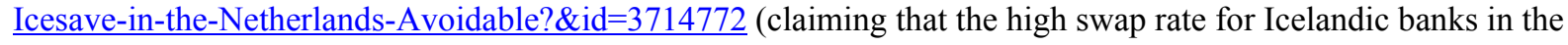
market evidenced awareness of underlying liquidity troubles, but regulators did not take market behavior into account when analyzing liquidity risk).

${ }^{36}$ John Glover, Moody's Blasted for Giving Icelandic Banks Top Rating, BLOOMBERG.COM, February 26, 2007, http://www.bloomberg.com/apps/news?pid=20601087\&sid=ailqCAI6I8Nk\&refer=home

${ }^{37}$ See note 284 infra. 
increasing the level of systemic risk in the economy. It was not until too late that the Icelandic government realized the consequences of implying that it would bail out its oversized banking sector. Elsewhere talk of implicit guarantees by the European Union of Greek sovereign debt ${ }^{38}$ and by the United States of Freddie Mac and Fannie Mae securities ${ }^{39}$ exacerbated systemic risk problems in a similar fashion.

Fourth, high government spending and market initiatives by the Icelandic government further inflated the financial bubbles appearing there in the mid-2000s. Although some urged that the government cut expenses during the boom, real public expenditure rose more than $40 \%$ between 2003 and 2009. ${ }^{40}$ In particular, the government dramatically increased liquidity in the real estate market by expanding the state-run Public Housing Fund's lending, even as the privatized banks created a private market that provided (for the first time) real estate lending. ${ }^{41}$ The government poured resources into the state-owned energy company Landsvirkjun, funding the building of the largest power plant $(690 \mathrm{MW})^{42}$ in the country's history to provide electricity for a huge Alcoa aluminum plant, a public-works project costing $\$ 4$ billion (about $35 \%$ of Iceland's GDP in 2003). ${ }^{43}$ This endeavor added considerable fuel to the boom, contributing to overheating the economy and further inflating the financial bubble. ${ }^{44}$ Similarly, government housing policies in Europe and North America contributed to housing bubbles ${ }^{45}$ and economic

\footnotetext{
${ }^{38}$ See Arthur Beesley, Frantic EU Efforts to Develop Conditional Rescue for Greece, IRISH TIMES, Feb. 11, 2010, at 18 (noting that implicit guarantee of support for all euro members is not enough to avoid speculative attacks in the market and observing that public statements of support by EU for Greece are designed to prevent a "full-blown sovereign debt crisis taking hold in the euro zone"); Paul Taylor, Anxiety Rises in Euro Zone Bond Market, INT'L Herald TriB., as published by N.Y. Times OnLine, Nov. 30, 2009, http://www.nytimes.com/2009/12/01/business/global/01 inside.html (last visited Mar. 14, 2010) (noting that early in the financial crisis Germany made clear that any nation having trouble paying its sovereign debt would be helped).

${ }^{39}$ See Fed. Res. Board, Remarks by Alan Greenspan on Government-sponsored enterprises to the Conference on Housing, Mortgage Finance, and the Macroeconomy, Federal Reserve Bank of Atlanta, (May 19, 2005), available at http://www.federalreserve.gov/boardDocs/Speeches/2005/20050519/default.htm (stating in 2005 that the belief of investors in the implicit government backing of housing-related government-sponsored enterprises (Fannie Mae and Freddie Mac) creates systemic risks for US financial system as the institutions grow very large).

${ }^{40}$ Haukur Pór Hauksson, The Public Spending Explosion (Icelandic: Útgjaldasprenging hins opinbera), Pjóðmál Magazine, Volume 5, Issue 1, Spring 2009.

${ }^{41}$ See notes 191 - 194 infra.

${ }^{42}$ Landsvirkjun, Key Figures of the Kárahnjúkar Hydroelectric Project, available at http://www.karahnjukar.is/EN/article.asp?catID=323\&ArtId=495.

${ }^{43}$ Armann Thorvaldsson, Frozen AsseTs: How I LiVED ICELAND‘s BoOM AND BUST 150 (2009). Aluminum production is heavily dependent on electricity. See generally U.S. Energy Information Administration - Energy Consumption (aluminum), http://www.eia.doe.gov/emeu/mecs/iab98/aluminum/fuel.html (last visited Apr. 6, 2010) ("Electricity represents $76 \%$ of the [aluminum] industry's energy consumption, most of which is used during the electrolysis of alumina.").

${ }^{44}$ See note 281 infra.

${ }^{45}$ See Brent J. Horton, In Defense of Private-Label Mortgage-Backed Securities, 61 FLA. L. REV. 827 (2009) (arguing that government sponsored entities competing in the mortgage-backed securities marketplace together with federal housing policy caused America's unsustainable housing bubble); Fred Kempe, The Week Ahead/The News in Perspective, Europe: A Tug-of-War Over the Economy, WALL ST. J., Feb. 18, 2006, at A2 ("the [European Central Bank's] bargain rates, which in real terms provide free money, have helped inflate a housing bubble to near bursting in several European countries. Data show that the latest cyclical rise in housing prices in the euro zone has been almost as powerful as in the U.S.”); Jessica Bown, Where in the World to Beat the Credit Crunch?, SUNDAY TIMES
} 
stimulus measures since the beginning of the financial crisis may be laying the foundation of future bubbles. ${ }^{46}$ Concern over bubbles has soared in recent years ${ }^{47}$ - even as there continues to be significant confusion over just what constitutes a "bubble" 48 - and understanding the role of fiscal policy in creating and inflating whatever-it-is-that-we-ultimately-define-as-a-bubble is critical for future efforts at avoiding them.

This Article describes the development of the Icelandic financial crisis and the problems in the policy responses to both the boom and the bust, providing three important contributions. First, this Article provides an analysis of the Icelandic crisis that focuses on these policy failures, showing how errors unrelated to deregulation contributed to the crisis. When the Icelandic crisis is properly evaluated, it is best understood as a failure of regulators to pay attention to monetary policy (failing to consider the impact of a strong currency and high interest rates), of regulators to use adequate models (ignoring the carry trade), and of excessive government involvement in expanding markets (the Public Housing Fund expansion, the guarantees of the banks, and the power plant investment). Second, it describes the institutional failures that exacerbated the Icelandic crisis, suggesting measures that other economies could take to avoid cascading meltdowns of financial institutions. Much of the English-language literature on the Icelandic crisis neglects these issues, in part because some of the material necessary to follow the connections is available only in Icelandic. ${ }^{49}$ By making use of that material, we are able to offer

(LONDON), May 25, 2008, Features (Money), at 6 (citing low interest rates in countries such as Ireland and Portugal as leading to housing bubbles); Landon Thomas Jr., The Irish Miracle Fizzles, N.Y. TIMES, Jan. 4, 2009 , § BU, at 1 (citing "low interest rates, a wave of inward immigration and a bank lending spree" as causes of Ireland's housing bubble).

${ }^{46}$ NeIl M. BArofsky, Office of the Special Inspector General for the Troubled Asset Relief Program QUARTERLY REPORT TO CONGRESS 6 (January 30, 2010), available at http://www.sigtarp.gov/reports/congress/2010/January2010 Quarterly Report to Congress.pdf. ([E]ven if TARP saved our financial system from driving off a cliff back in 2008 [ . . ] we are still driving on the same winding mountain road, but this time in a faster car.)

${ }^{47}$ See generally Aaron Unterman, Innovative Destruction-Structured Finance and Credit Market Reform in the Bubble Era, 5 HASTINGS Bus. L.J. 53, 54 (2009) ("Asset bubbles are not new phenomena, and in recent years they have become a hallmark of developed economies."); Robert H. Frank, Flaw in Free Markets: Humans, N.Y. TIMES, SEPT. 13, 2009, § BU, at 4 (expressing concern over the "housing bubble," the "financial bubbles," and "asset bubbles").

${ }^{48}$ Peter M. Garber, FAMOUS FiRst BubBles: The Fundamentals of EARLY MANias 4 (2001) ("Bubble is one of the most beautiful concepts in economics and finance in that it is a fuzzy word filled with import but lacking a solid operational definition. Thus, one can make whatever one wants of it.").

${ }^{49}$ There are three important English language sources attempting a serious assessment of the Icelandic crisis. Where possible we have included citations to these works, in part to reassure non-Icelandic-speaking readers that our account is not purely fictional and in part to provide assessments of how the particular points of view of these authors are reflected in their accounts. In addition, the business press carried a significant number of stories on Iceland during the boom and crash, particularly the UK-based Financial Times. These accounts are: Boyes, supra note 4; Thorvaldsson, supra note 43; and Jonsson, supra note 24. Boyes is a Financial Times reporter who covered Iceland and who spent considerable time there after the crash in an effort to untangle the story. Thorvaldsson was an executive at Kaupthing in Iceland and Kaupthing, Singer \& Friedlander in the UK and has an obvious interest, expertise, and potential bias in the subject matter. Jonsson was head of research and chief economist at Kaupthing and shares Thorvaldsson's potential for interest, expertise, and bias. We do not count as a serious assessment the account by Michael Lewis in Vanity Fair. Lewis, Wall Street on the Tundra, supra note 21. Although Lewis' work is generally excellent - and one of us is a serious admirer of his pathbreaking Moneyball (2003), despite a complete lack of interest in baseball as a sport -and his Liar's Poker is a classic account of the trading culture on Wall Street 
a more complete analysis. Finally, this Article draws lessons from Iceland's experience that highlights neglected connections between monetary and fiscal policy and financial regulation. As large and small nations and multilateral institutions embark on changes to financial regulation around the world, Iceland's experience serves as a dramatic object lesson of the perils of ignoring these connections in the process often billed as "reform".

In Part I, we establish the global context for the Icelandic crisis, emphasizing the critical role that developments in financial markets had in setting the stage. In Part II, we describe the Icelandic boom and financial crisis, identifying the contributors to each and the key policy errors that worsened the crisis. In Part III, we draw lessons from the Icelandic crisis and compare these to the policy prescriptions offered by others, demonstrating how misunderstanding the context and causes of the crisis lead to erroneous conclusions about regulating financial markets. We conclude with thoughts on avoiding the "next Iceland" and the implications of the analysis for the redesign of financial market regulation.

\section{The Interconnectedness of Open Economies}

Although Iceland's economy had significant problems even without the difficulties caused by world events, the situation in which the Icelandic economy found itself in 2008 would have been radically different absent the global financial crisis and the links between the Icelandic economy and the rest of the world. We thus begin by briefly describing the international financial system in place at the start of the twenty-first century and the role it provided for small, open economies like Iceland. This system included five key attributes:

(1) Globalized financial markets with relatively free capital movement;

(2) Adoption of loose monetary policies by most developed country central banks;

(3) Adoption of stimulative fiscal policy by most developed country governments;

(4) Floating exchange rates; and

(5) Financial regulations that lagged developments in the world financial markets.

Each of these played an important role in creating the conditions that led to the crisis. Importantly, all of these conditions persist today and their impacts are not limited to small economies.

\section{A. Free Movement of Capital}

After World War II, financial markets around the world grew increasingly interconnected as technological change reduced the transactions costs of international operations. ${ }^{50}$ For example,

(Michael Lewis, LIAR's POKER (1990)) - Lewis unaccountably opted for sensationalism and barroom interviews rather than his trademark in depth research. Perhaps the blame belongs with Vanity Fair rather than Lewis, but in any event his account is neither serious nor accurate. It does represent important evidence of how the world perceived the Icelandic crisis, however.

${ }^{50}$ There is powerful evidence that global financial markets were inter-connected prior to World War I and that the degree of integration present then was not reached again until quite recently. See, e.g., R.C. MITCHIE, THE GLOBAL SECURITIES MARKET: A HISTORY 158 (2008) (describing pre-World War I market as "a pool of securities shared by the main markets and capable of moving easily, quickly, and cheaply between the different financial centers in response to minute variation in price"). One key difference between that earlier period and today is that it was not nearly as easy to physically travel and the costs of communication and entry into international financial markets limited participation to a relatively small slice of the population in both issuing and buying securities. See David Held, et al., Global Transformations: Politics, Economics And Culture 194-195 (1999) (noting that international financial trade prior to World War I was largely in government bonds.). 
during the 1920s, transatlantic telephone calls were expensive and difficult and travel between Europe and North America required ocean liner voyages lasting four days or more. ${ }^{51}$ These transactions costs limited opportunities for transcontinental investments by raising their costs. After World War II, these costs fell dramatically. The cost of a three-minute phone call between New York and London dropped from \$250 in 1930 to a few cents in recent years. ${ }^{52}$ Similarly, transatlantic flights became both possible and more affordable, cutting travel times from days to a matter of hours ${ }^{53}$ and prices by a factor of 10 from 1949 to $2009 .{ }^{54}$ These falling transactions costs made international investing cheaper.

Just as dramatic as the decline in transactions costs were the changes in the legal rules governing international finance. During the same period when transactions costs were plummeting, controls on capital movement, common in developed economies in the 1950s and 1960 s, were increasingly being dismantled. ${ }^{55}$ After the 1970 s, legal barriers fell even further. As Manuel Guitián noted, "[a]n essential development in the international economy since the collapse of the Bretton Woods order has been the expansion in the scale of gross and net capital flows and the resulting integration of national financial markets. ${ }^{, 56}$

This growing internationalization of capital markets was not an accident but a deliberate policy choice by developed countries, in large measure driven by western Europeans and U.Strained economists working at the International Monetary Fund. ${ }^{57}$ Similarly, the dismantling of domestic capital controls also reflected a strong commitment by western European economies to a global financial system. ${ }^{58}$ Regardless of whether one thinks that was a wise choice, as we do, or

${ }^{51}$ See Bob Dickinson \& Andy Vladimir, SElling THE SEA: An InSIDE LOOK AT THE CRUISE INDUSTRY 19 (2 ${ }^{\text {nd }}$ ed. 2007).

${ }^{52}$ Martin Wolf, Why Globalization Works 119-120 (2004). In real terms, \$250 in 1930 would be $\$ 3,389.54$ in 2011. (Calculation via the Bureau of Labor Statistics inflation calculator, http://data.bls.gov/cgi-bin/cpicalc.pl.)

53 See Andrew Evans, Super Colossal Transatlantic Travel, Circa 1949, National Geographic Intelligent Travel (August 20, 2009) available at http://blogs.nationalgeographic.com/blogs/intelligenttravel/2009/08/super-colossaltransatlantic-t.html.

\footnotetext{
${ }^{54}$ See Evans, supra note 53.
}

${ }^{55}$ Manuel Guitián, Capital Account Liberalization: Bringing policy in line with reality, in CAPITAL CONTROLS, EXChange RATeS, AND MONETARy POLICY IN THE WORLd ECONOMY (Sebastian Edwards, ed. 1997) 71, 74 ("Perhaps the most critical feature of the recent evolution of capital movements has been the relaxation of capital controls, the bulk of which took place in the context of a broad liberalization and deregulation of domestic financial markets in industrial countries.”); Barry Eichengreen, GLOBALIZING CAPITAL: A HISTORY OF THE INTERNATIONAL MONETARY SYSTEM 1 ( $2^{\text {nd }}$ ed. 2008) ("The three decades following World War II were then marked by the progressive relaxation of controls and the gradual recovery of international capital flows. The fourth quarter of the twentieth century was again one of significant capital mobility. And the period since the turn of the century has been one of very high capital mobility — in some sense even greater than that which prevailed before 1913.").

\footnotetext{
${ }^{56}$ Guitián, supra note 55, at 74.
}

${ }^{57}$ Rawi Abdelal, CAPitAl Rules: The CONSTRUCTION OF Global FinANCE 3 (2007) (“European policymakers conceived and promoted the liberal rules that compose the international financial architecture."). Abdelal sees the role of the United States in liberalization as "ad hoc" rather than the result of a uniform policy, and emphasizes that the EU and OECD rules both developed without significant U.S. influence. Id. A somewhat different explanation puts IMF staff economists in the driver's seat on liberalization. See Jeffrey M. Chwieroth, CAPITAL IDEAS: THE IMF AND THE RISE OF FINANCIAL LIBERALIZATION (2009) (arguing the IMF staff promoted reduction of capital controls).

${ }^{58}$ Abdelal, supra note 57, at 105 (noting that by late 1980s "capital account liberalization was becoming the usual behavior of OECD members" and that this was driven by Europeans). 
an unwise one, as critics of globalization from both the left and the right do, it is important to recognize that this was a deliberate policy rather than an accident because the success or failure of the regulatory infrastructure put into place as part of this choice tells us something important about the ability of regulators to regulate effectively.

The combination of these trends progressively freed capital to move about the world as investors sought higher returns and increasingly democratized access to international capital markets. As a result, the decline in the transactions costs of international financial transactions together with the rapid decline of communication costs meant that over time an ever-larger percentage of investors had worldwide access to investments outside their own economies. While there have been some dissenting voices (most notably after the Asian Financial Crisis in 1997), ${ }^{59}$ the globalization of financial markets and loosening of restrictions on capital controls reflects a broad consensus among policy makers around the world. ${ }^{60}$ Although not impossible to reverse, these changes are now firmly embedded in the international financial architecture and would be both costly and difficult to change more than marginally.

The benefits of these changes accrued to a wide range of interest groups, most notably in developed economies like the United States and the many European countries that are net importers of capital. For example, the United States government borrowed $\$ 4.4$ trillion between 1999 and 2006, a figure made all the more astonishing because it represents only a bit more than 30 percent of total gross cross-border investments by other countries during the period. ${ }^{61}$ These capital inflows into developed economies have largely come from developing country economies.

Moreover, developments in finance during this period allowed borrowers as well as investors much greater access to international capital markets. Securitization, particularly of mortgages and credit card balances, vastly expanded the pool of consumer credit in the United States and Europe by creating investment instruments that reduced the risk of individual borrowers' defaults by pooling groups of debts and then dividing the pool into a range of

\footnotetext{
${ }^{59}$ See, e.g., The speech of Dr. Mahathir, the Prime Minister of Malaysia, at the Islamic Cultural Center in Northbrook, available at http://www.lariba.com/knowledge-center/articles/pdf/Mahathir\%20Mohammad\%20$\% 20$ The $\% 20$ speech $\% 20$ of $\% 20$ Dr $\% 20$ at $\% 20$ LARIBA.pdf (advocating greater financial controls to limit "speculation"). Academic evidence on whether "speculation" was the problem was more mixed. See e.g. Janice A. Loftus and John A. Purcell, Post-Asian Financial Crisis Reforms: An Emerging New Embedded-Relational Governance Model, 18 ACCOUNTING, Business AND FinANCIAL HistORY 335, 336 (November 2008) (claiming that "... [T] he Asian financial crisis was the catalyst for a change from broadly defined neo-liberal societal governance in favour of the emerging embedded-relational governance model."). But see Suiwah Leung, Banking and Financial Sector reforms in Vietnam, 26 ASEAN ECONOMIC BULLETIN 44, 46 (April 2009) (noting that Vietnam deregulated banks during this period); and James J. Kung and Wing-Keung Wong, Profitability of Technical Analysis in the Singapore Stock Market: Before and After the Asian Financial Crisis, 24 JOURNAL OF ECONOMIC INTEGRATION 135 (March 2009) (noting that Singapore's reaction to the Asian Financial Crisis was a strategy of liberalization, resulting in enhanced market performance); Hue Hwa Au Yong and Robert Faff, Asia-Pacific Banks Risk Exposures: Pre and Post the Asian Financial Crisis, 18 APPLIED FInANCIAL ECONOMICs 431 (March-April 2008) (finding that among banking institutions affected by the Asian Financial Crisis, bank portfolios performed better when subject to private monitoring but not governmentally-imposed restrictions on their holdings).

${ }^{60}$ Abdelal, supra note 57, at 105.

${ }^{61}$ Mathew Higgins \& Thomas Klitgaard, Financial Globalization and the U.S. Current Account Deficit,13(11)

CURRENT ISSUES IN ECONOMIC AND FINANCE 1, 1 (Dec. 2007) available at

http://www.ny.frb.org/research/current issues/ci13-11.pdf
} 
products offering different risk levels. ${ }^{62}$ While these products reduced the known risks of individual debtor defaults, ${ }^{63}$ they not only did not reduce the systemic risk of widespread defaults but increased such risks in some. ${ }^{64}$ These risks were further increased by government policies promoting housing booms in the United States, Ireland, Spain, and elsewhere. ${ }^{65}$ The result was an explosion in housing prices, not just in the United States but also throughout the developed world, and rising consumer debt levels in many developed countries. ${ }^{66}$ Another result was increasing investment in these products by banks and other investors around the world seeking higher investment returns. ${ }^{67}$

By the early 2000s, these trends combined to make at least some investments in any developed economy available to even small investors in other countries. For example, internet banks allowed investors in one country to invest in another without either physically visiting the other country or having to depend on the mail to make or redeem investments. ${ }^{68}$ Many countries, including the United States, encourage foreign investors to make use of domestic bank accounts. For example, the United States exempts from income taxation the interest earned by non-U.S. persons on U.S. bank accounts. ${ }^{69}$ Investors in many countries increasingly took advantage of

${ }^{62}$ See Richard J. Rosen, The role of securitization in mortgage lending, CHICAGo FED LETTER (No. 244) (Nov. 2007); Martin Hellwig, Systemic Risk in the Financial Sector: An Analysis of the Subprime-Mortgage Financial Crisis, (Nov. 2008) available at http://www.coll.mpg.de/pdf_dat/2008_43online.pdf.

${ }^{63}$ Rosen, supra note 62.

${ }^{64}$ See, Reggie Middleton, The Asset Securitization Crisis - Part I, SeekingAlpha (May 7, 2008) available at http://seekingalpha.com/article/76202-the-asset-securitization-crisis-part-i ("Even with extremely low interest rates, we would not have seen the carnage that we have witnessed recently if those who originated the mortgages were to be held ultimately responsible for their performance.").

${ }^{65}$ See James Barth, THE RiSE AND FALl OF THE US Mortgage AND CREDIT MARKETS: A COMPREHENSIVE ANALYSIS OF THE MARKET MELTDOWN (2009) (US mortgage market); Viral V. Acharya, et al., GUARANTEED TO FAil: FAnNie Mae, Freddie MaC, AND the Debacle of Mortgage FinANCe (2011) (same); Peter Wallison, SERVING TWO MASTERS, YET OUT OF CONTROL (2001) (same, noting problems existing before crisis); David McWilliams, Follow the Money (2010) (Ireland); Christopher Mayer \& R. Glenn Hubbard, House Prices, Interest Rates, and the Mortgage Market Meltdown, Columbia Business School (2009) available at https://www4.gsb.columbia.edu/null/download?\&exclusive=filemgr.download\&file id=3549 (discussing all three economies); Bill Seyfried, Monetary Policy and Housing Bubbles: A Multinational Perspective available at http://www.aabri.com/OC09manuscripts/OC09011.pdf (discussing multiple markets and concluding that interest rates were " too lowOC09011- Economics

for Ireland and Spain. Loose policy was also found in the United States and, to a lesser extent, the United Kingdom.").

${ }^{66}$ Middleton, supra note 64 (U.S. spending);

${ }^{67}$ Mark Pittman, Evil Wall Street Exports Boomed With `Fools' Born to Buy Debt, BLOOMBERG.COM, October 27, 2008 http://www.bloomberg.com/apps/news?pid=20601109\&refer=home\&sid=a0jln3.CSS6c (claiming European securitization increased six-fold from 2000-2007 and that "Three Icelandic banks borrowed enough to buy $\$ 228$ billion of assets, most of them securitizations, turning the country's financial system into a hedge fund.").

${ }^{68}$ See, e.g., HSBC, offshore banking web page, ("We provide offshore banking for customers in over 200 countries and territories") available at http://www.offshore.hsbc.com/1/2/home; NatWest, Offshore Banking, available at http:/www.natwestinternational.com/nw/offshore-banking/internet-banking.ashx ("Internet banking is the secure, easy and convenient way for you to manage your offshore accounts.").

${ }^{69}$ See Craig M. Boise, Regulating Tax Competition in Offshore Financial Centers, in REGULATORY COMPETITION AND OFFSHORE FINANCIAL CENTERs 65 (Andrew P. Morriss, ed., 2010) (noting U.S. competes for foreign debt investment "compete for foreign debt investment by exempting outbound portfolio interest flows from withholding 
such opportunities in the 2000 s as they sought higher returns than were possible on investments domestically. $^{70}$

Analysts around the world were not completely unaware of the risks posed by global capital markets and free movement of capital. The Asian Financial Crisis in 1997-1998 demonstrated that so-called "hot money" could flow out of economies as quickly as it flowed in, when declines (current or anticipated) in the value of the local currency cut the real returns offered by local currency denominated investments. ${ }^{71}$ Economist Joseph Stiglitz warned the Icelandic Central Bank of the dangers of hot money flows in $2001 .^{72}$ Moreover, the problematic nature of many developed countries' consistent current account deficits was well known long before the current financial crisis. ${ }^{73}$ Because American savings rates are so low, the United States in particular has been running a significant current account deficit with respect to countries with high savings rates (e.g. China) ${ }^{74}$ and many analysts and policymakers regularly expressed concern over the implications of such persistent deficits. ${ }^{75}$

Despite this widespread awareness of the potential for problems, regulators in the United States, European Union, and multilateral institutions failed to adequately safeguard the global financial economy from the systemic risks created by increased globalization of financial

or other income taxation.").

${ }^{70}$ Jeffrey Frankel, Global Imbalances and Low Interest Rates: An Equilibrium Model vs. a Disequilibrium Reality, 7 (June 19-20, 2006) available at http://ksghome.harvard.edu/ jfrankel/BISwpCmtsCaballeroFG-AuCISENR.pdf ("Low short-term rates have led to the "carry trade:" money has gone into bonds, stocks, real estate, emerging markets, and commodities - anywhere that it might earn a higher return than the very low rates that were on offer in the US and Japan.”).

${ }^{71}$ Asian Development Bank, Private Sector Operations Strategic Directions And Review 7, August 2001, available at http://www.adb.org/documents/policies/pso/Strategic Directions.pdf. See also Kuan-Min Wang and Yuan-Ming Lee, The Stock Market Spillover Channels in the 1997 Asian Financial Crisis, 26 INTERNATIONAL RESEARCH JOURNAL OF FINANCE \& ECONOMICS 105, 131 (2009) (discussing role of short term speculation); R.T. Naylor, Hot MONEY \& THE Politics OF DEBT 11-12 ( $3^{\text {rd }}$ ed. 2004) (critical of "the stupendous growth in the amount of hot and homeless money ready at any time to leave its present abode for more hospitable climes whenever a tiny interest rate spread, exchange rate change, or shift in the political environment beckons.”)

${ }^{72}$ Joseph E. Stiglitz, Monetary and Exchange Rate Policy in Small Open Economies: The Case of Iceland, Central Bank of Iceland Working Papers No. 15, 18 (2001) ("capital flows, especially short term flows, give rise to large externalities, and it is the responsibility of government to try to address these externalities, much as it would do given any other set of externalities, such as those arising out of pollution.") (emphasis in original).

${ }^{73}$ See, e.g., Sebastian Edwards, Is America's Current Account Deficit Sustainable? And If so How Costly Is Adjustment Likely to Be?, 2005 BROOKINGS PAPERS ON ECONOMIC ACTIVITY 211 (2005) (concluding that it was not sustainable); Maurice Obstfeld \& Kenneth Rogoff, The Unsustainable U.S. Current Account Position Revisited in G7 Current AcCount Imbalances: Sustainability And AdJustment (Richard H. Clarida, ed., 2007) 339 (same).

${ }^{74}$ Edwards, supra note 73.

${ }^{75}$ See C. Fred Bergsten, Peterson Inst. for Int'1 Econ., Testimony Before the Budget Committee of the United States Senate: The Current Account Deficit and the US Economy (Feb. 1, 2007), available at http://www.iie.com/publications/papers/paper.cfm?ResearchID=705 ("The huge and growing international trade and current account imbalances, centered on the US external deficits and net debtor position, represent the single greatest threat to the continued prosperity and stability of the United States and world economies."); Eiji Ogawa \& Takeshi Kudo, Possible Depreciation of the US Dollar for Unsustainable Current Account Deficit in the United States, CESIFO F., Winter 2007, at 24 (concluding that the US current account deficit is unsustainable and showing how much the US dollar should depreciate in order to reduce the current account deficit). 
markets. For example, in both the European Union and the United States, banking regulators have required deposit 'insurance' guarantees. ${ }^{76}$ Such guarantees are typically backed by insurance funds adequate to cope with the collapse of smaller institutions but inadequate to address large scale banking problems without the addition of significant additional resources. ${ }^{77}$ So long as there was not a systemic banking crisis, this strategy kept the deposit insurance premiums charged to the banks to fund the deposit insurance low. However, when large scale problems appeared, regulators had to scramble to find alternative resources with which to prop up large financial institutions. ${ }^{78}$ This failure exacerbated the moral hazard problem posed by deposit insurance schemes since it encouraged depositors to ignore risks in an environment in

\footnotetext{
${ }^{76}$ See FDIC, A Brief History of Deposit Insurance in the United States (1998) available at http://www.fdic.gov/bank/historical/brief/brhist.pdf (describing U.S. system); Michele Fratianni, Bank Deposit
} Insurance in the European Union, in POLITICS AND INSTITUTIONS IN AN INTEGRATED EUROPE (Barry J. Eichengreen, Jeffry A. Frieden, \& Jurgen von Hagen, eds. 1995) 144, 155 (summarizing EU approach to deposit insurance). Government deposit 'insurance' is not a true insurance scheme but a subsidy to depositors. See Roger E. Meiners \& Bruce Yandle, Deposit Insurance, Liability, and the U.S. Savings and Loan Debacle, 4 INS. L. J. 181 (1991).

${ }^{77}$ See, e.g., Yasuhiro Maehara, Comment, in Richard J. Herring \& Robert E. Litan, Financial Regulation in the Global Economy 153, 155 (1994) ("Deposit insurance is a policy to protect small depositors in the event of a bank failure, while the lender-of-last resort function aims at maintaining the safety and soundness of the financial system as a whole."); Markus K. Brunnermeier, et al., THE FundAMENTAL PRINCIPLES OF FINANCIAL REGULATION 6 (2009) (noting difference between protecting depositors and systematic risk). See also The High-Level Group on Financial Supervision in the EU (chaired by Jacques de Larosiere), REPORT 28 (25 Feb. 2009) (noting "substantial differences in the modalities related to deposit insurance" as an example of "excessive diversity" in financial regulation).

${ }^{78}$ See Maximilian J.B. Hall, How Good Are EU Deposit Insurance Schemes in a Bubble Environment? in AsSET Price BubBles: IMPliCATIONS FOR MONETARY AND REgulatory Policies 145, 183, 186 (George G. Kaufman, ed. (2001) (criticizing EU deposit insurance scheme for failing to require access to supplemental state funding and finding that EU insurance schemes "compare badly" with U.S. system); Lars Nyberg, Financing of deposit insurance - a central banker's perspective, Speech, Sveriges Riksbank 1 (15 Sept. 2005) available at http://www.riksbank.se/pagefolders/21267/050915e.pdf ("In the EU as in most other developed economies in the world, deposit insurance is seen primarily as a form of consumer protection. Bank failures are few and far between and bank crises involving the entire system are something that most of us have only read about or heard about at a conference. Under these generally stable circumstances, the role of deposit insurance is limited to reimbursing the relatively few customers who are unfortunate enough to have deposits in the (al-ways) very small banks that once in a while have to be closed down."); Fratianni, Bank Deposit Insurance, supra note 76, at 169 (noting that EU Directive on Deposit-Guarantee Schemes allowed banks to remain in home country deposit guarantee scheme while operating abroad); Hans-Joachim Dubel, Europe's Second Pillar, InTERNATIONAL ECONOMY 32, 34-35 (Fall 2008) available at http://www.finpolconsult.de/mediapool/16/169624/data/TIE F08 Duebel.pdf (criticizing EU-nationbased deposit insurance and advocating EU-wide system); Martin Schuler, How Do Banking Supervisors Deal with Europe-wide Systemic Risk?, Centre for European Economic Research Working Paper 6-10 (2003) available at http://papers.ssrn.com/sol3/papers.cfm?abstract id=412460 (describing EU system for addressing systemic risks). Christine M. Bradley \& Lynn Shibut, The Liability Structure of FDIC-Insured Institutions: Changes and Implications, 18(2) FDIC BANKING REV. 1, 18 (2006) (noting that asset growth funded by nondeposit liabilities changes the FDIC's risk exposure but does not change the assessment base (which includes only domestic deposits) or the reserve ratio (which includes only insured deposits) and observing that large banks are much more reliant on nondeposit liabilities than small banks); Fed. Res. Board, Testimony of Chairman Alan Greenspan on Federal Deposit Insurance Reform Before the Committee on Banking, Housing, and Urban Affairs, U.S. Senate, (April 23, 2002), available at http://www.federalreserve.gov/boarddocs/testimony/2002/20020423/ ("From the very beginning, deposit insurance has involved a tradeoff. On the one hand, deposit insurance contributes to overall short-term financial stability and the protection of small depositors. On the other hand, deposit insurance induces higher risktaking, resulting in a misallocation of resources and larger long-term financial imbalances that increase the need for government supervision to protect the taxpayers' interests. . . . [A]ny reforms should be aimed primarily at protecting the interest of the economy overall, and not just the profits or market shares of particular businesses."). 
which those risks were substantial. ${ }^{79}$ More importantly, in a global economy, a country-based deposit insurance system - as European Union rules created - raised important issues about the adequacy of small countries' deposit insurance systems that are not difficult to recognize but which remained unaddressed by the sophisticated financial regulators in Europe. Similarly, issues from counter-party risk to dangers posed by financial institutions "too big to fail" were inadequately addressed prior to the financial crisis. ${ }^{80}$

The increased globalization of financial markets had many benefits, primarily by facilitating access to capital around the world. For example, as early as the 1970s, access to Eurodollar markets cut interest costs for U.S. corporate borrowers by $1-2$ percentage points. ${ }^{81}$ Nonetheless, these benefits came at a cost of increased risk of the spread of financial problems across borders. Financial regulators found themselves unable to keep up with the expansion of global finance and national and multinational regulatory regimes even in developed economies lagged well behind events. More powerful regulators might have avoided some problems or, conversely, might have enabled bad decisions to become catastrophic; greater deregulation might have prevented investor complacency induced by regulators' perceived expertise and quasisovereign guarantees of financial institutions or unleashed destructive forces more broadly. As there is no definitive test to determine the answer to which outcome would have occurred, advocates of both positions use the current crisis to argue for their positions. What does appear certain is that financial regulators did not adapt quickly to changes in financial markets while market participants did. To take just one example, the market for U.S. subprime mortgagebacked securities grew from $\$ 65$ billion in 1995 to $\$ 332$ billion in 2003 , with the percentage of subprime loans that were securitized rising from less than $30 \%$ in 1995 to over $58 \%$ in $2003 .{ }^{82}$ By 2006 the market in subprime collateralized debt obligations (CDOs) was more than $\$ 50$ billion. ${ }^{83}$

That regulators were not able to keep up with some developments in financial markets does not mean they were not able to act in ways that had significant impacts. The U.S. Federal Reserve's monetary policy had an "unusually large" deviation from the "Taylor Rule" (which describes the monetary policy followed during the "Great Moderation" beginning in the early

\footnotetext{
${ }^{79}$ PAtricia A. MCCOY, The Moral HaZARd IMPLiCATIONS OF DEPOSIT INSURANCE: THEORY AND EVIDENCE 12 (2007), available at http://www.imf.org/External/NP/seminars/eng/2006/mfl/pam.pdf.

${ }^{80}$ Jon Gregory, COUNTERPARTY CREDIT RISK (2010); RESTORING FINANCIAL STABILITY: How TO REPAIR A FAILED SYSTEM 27 (Viraln Acharya, et al., eds. 2009).

${ }^{81}$ Taxecon Associates, Consequences of Imposing the U.S. 30 Percent Withholding Tax on Interest Paid to or by Netherlands Antilles Finance Subsidiaries of U.S. Corporations, July 1982 at 587 in "Tax Evasion through the Netherlands Antilles and Other Tax Haven Countries", Hearings Before a Subcommittee of the Committee on Government Operations, House of Representatives, April 12 and 13, 1983 (estimating savings at 2-3\%, although cautioning that this might overestimate savings because users of finance subsidiaries were those with higher credit ratings). See also Craig M. Boise \& Andrew P. Morriss, Change, Dependency, and Regime Plasticity in Offshore Financial Intermediation: The Saga of the Netherlands Antilles, 45 TEX. INT'L L. J. 377, 407-08 (2009) (discussing importance of access to Eurodollar markets).

${ }^{82}$ Souphala Chomsisengphet \& Anthony Pennington-Cross, The Evolution of the Subprime Mortgage Market, FEDERAL RESERVE BANK OF ST. LOUIS REVIEW 31, 37 (2006).

${ }^{83}$ Yongheng Deng, Stuart A. Gabriel, \& Anthony B. Sanders, CDO Market Implosion and the Pricing of Subprime Mortgage-Backed Securities, George Mason Univ. Working Paper 4 (March 2009).
} 
1980s) in the early 2000s ${ }^{84}$ Whether this was wise or not is not the point here, what is important is that these were "purposeful deviations from the 'regular' interest-rate settings based on the usual macroeconomic variables." 85

The lag between regulators' capacities and events left the financial system with the worst of both worlds: a rapidly growing global financial system equipped with regulators powerful enough to cause significant harm through their missteps but without sufficient ability to adapt to rapidly changing circumstances. ${ }^{86}$ Despite tentative steps to increase regulatory capacity since the financial crisis, ${ }^{87}$ this situation remains true today in important ways. ${ }^{88}$ For example, in the seemingly now routine crises of 2011-2012 the ECB, France, Germany, and the IMF sought to find a solution to Greece's financial problems; yet there is still no consensus on the proper approach to that or similar situations. ${ }^{89}$ Moreover, there is little consensus among even advocates of increased financial regulation over which steps could address the problems exposed by the

\footnotetext{
${ }^{84}$ John B. Taylor, GetTING OFF TRACK 2-3 (2009).

85 Taylor, supra note 84 , at 3 .

${ }^{86}$ Such capacity is impossible for regulators to obtain, no matter how competent. Friedrich A. Hayek, The Use of Knowledge in Society, 35 AM. ECON. REV. 519 (1945). A version of this argument was also articulated by Ludwig von Mises in the early twentieth century socialist calculation debate, where it was known as the "calculation problem." Ludwig von Mises, Die Wirtschaftsrechnung im Sozialistischen Gemeinwesen (Economic Calculation in the Socialist Commonwealth), in COLleCtivist ECONOMIC PlANNING, CRITICAL STUdIES ON THE POSSIBILITIES OF SocIALISM (Friedrich A. Hayek ed., 1935). Even if one credits regulators with more theoretical capacity than Hayek did or we do, they clearly did not have such capacity in the 1990s and 2000s.
}

${ }^{87}$ See, e.g., Financial Stability Oversight Council created by the Dodd-Frank financial reform statute. P.L. 111-203 sec. 111-123 (July 21, 2010). See also Douglas D. Evanoff \& William F. Moeller, Financial regulation in a postcrisis environment, CHICAGO FED LETTER (Sept. 2010) (describing various reform proposals discussed at the Chicago Fed's conference on bank structure and competition in May 2010).

${ }^{88}$ See Daniel M. Gallagher Jr., Co-acting Dir., Div. of Trading and Markets, U.S. Sec. and Exch. Comm'n, Remarks before Fintel's 2nd Annual Global Financial Services Centers Conference: Reshaping the World's International Financial Services Centers (May 19, 2009), in 1783 PLI/Corp 257, 262 (2010) ("Substantial challenges remain for regulators of the financial sector, and enhanced global dialogue will play a key role in meeting those challenges. One of the biggest challenges includes the identification of firms whose failure would have profound global systemic implications."); Fed. Res. Board, Testimony of Governor Daniel K. Tarullo on Equipping Financial Regulators With the Tools Necessary to Monitor Systemic Risk, Before the Subcommittee on Security and International Trade and Finance, Committee on Banking, Housing, and Urban Affairs, U.S. Senate, (Feb. 12, 2010), available at http://www.federalreserve.gov/newsevents/testimony/tarullo20100212a.htm ("Financial activities and risk exposures are increasingly globalized. A system without a common detailed taxonomy for securities and counterparties and comparable requirements for reporting across countries would make assembling a meaningful picture of the exposures of global institutions very difficult. Efforts to improve data collection are already under way in the European Union, by the Bank of England and the Financial Services Authority, and the European Central Bank, which has expressed support for developing a unified international system of taxonomy and reporting. The Financial Stability Board, at the request of the G-20, is initiating an international effort to develop a common reporting template and a process to share information on common exposures and linkages between systemically important global financial institutions.").

${ }^{89}$ See, e.g., Mark Gongloff, Here are the Four Disagreements Europe Has to Settle, Wall Street Journal MarketBeat (Dec. 7, 2011) available at http://blogs.wsj.com/marketbeat/2011/12/07/here-are-the-four-disagreements-europe-hasto-settle-by-tomorrow/ (listing lack of agreement on private sector participation, whether EFSF and ESM can operate concurrently, role of the IMF, and whether treaty changes are needed). 
financial crisis. ${ }^{90}$ Thus while many critics have claimed the financial crisis proves the need for greater regulatory powers, regulators already had considerable powers before the crisis which they either did not exercise or exercised inappropriately.

\section{B. Loose, Active Monetary Policies}

Most developed economies have central banks with considerable independence from political control, including the euro-area of the European Union, Great Britain, and the United States. ${ }^{91}$ Monetary policy in recent decades has focused on inflation targeting, with central banks using their influence on interest rates to slow economic growth through higher interest rates when inflation exceeds the target and to stimulate economic growth through lower interest rates when inflation is within the targeted zone. ${ }^{92}$ Because inflation was relatively low during the 1990s and 2000s, central banks in developed economies tended to focus on stimulating their economies through low interest rates. ${ }^{93}$ Particularly after the economic downturn that followed 9/11 began, the European Central Bank, Bank of Japan, Bank of England, and Federal Reserve all kept interest rates at or near historic lows in an effort to stimulate borrowing so as to promote economic growth. ${ }^{94}$ With hindsight, the wisdom of these policies has been questioned since the global financial crisis began, ${ }^{95}$ and a number of analysts now regard the provision of cheap credit as a contributing factor. ${ }^{96}$

${ }^{90}$ See Gallagher, supra note 88 ("In striving to develop the optimal regulatory solution there has been an ongoing debate over whether the optimum is a principles-based or rule based regime.”); Howard Schneider \& David Cho, U.S., Europe at Odds Over Financial Reform, WASH. POST, Mar. 13, 2010, at A01 (discussing disagreements between U.S. and Europe over where to initiate stricter financial reforms and where to initiate more lenient financial reforms).

${ }^{91}$ See Sylvester C.W. Eijffinger \& Jakob de Haan, The Political Economy of Central-Bank Independence, Special Papers in International Economics, No. 19 22-28 (May 1996) (summarizing measures of independence for various central banks); Sebastian Dellepiane Avellaneda, Gordon Unbound: The Heresthetic of Central Bank Independence in Britain, UCD Geary Institute Discussion Paper Series WP2010/52, Dec. 16, 2010, available at http://www.ucd.ie/geary/static/publications/workingpapers/gearywp201052.pdf.

92 See Ben S. Bernanke, et al., Introduction in INFLATION TARGETING: LESSONS FROM THE INTERNATIONAL EXPERIENCE 3, 3-4 (Ben S. Bernanke, et al. eds. 2001).

${ }^{93}$ Frankel, Global Imbalances, supra note 70, at 7 ("[A major factor in low interest rates] was easy monetary policy by the Federal Reserve Board, the European Central Bank (less so), the Bank of Japan (more so), and the People's Bank of China.").

${ }^{94}$ Frankel, Global Imbalances, supra note 70, at 7.

95 See, e.g. Greg Ip and Jon E. Hilsenrath, Debt Bomb: Inside the 'subprime' mortgage debacle --- Seeds of Excess: How Credit Got So Easy And Why It's Tightening --- Responses to S\&L Mess, Asian Crisis, Tech Bust All Fed Into the Boom, Wall Street J., August 7, 2007, at A1; David Malpass, Near-Zero Rates Are Hurting the Economy, Wall Street J., December 4, 2009, at A25; Asian Development Bank, Private Sector Operations StrategiC DiRECTIONS AND REVIEW 7, August 2001, available at http://www.adb.org/documents/policies/pso/Strategic Directions.pdf. See also, Kuan-Min Wang and Yuan-Ming Lee, The Stock Market Spillover Channels in the 1997 Asian Financial Crisis, 26 INTERNATIONAL RESEARCH JOURNAL OF FINANCE \& ECONOMICS 105, 131 (2009).

${ }^{96}$ See, e.g. Robert Wade, Iceland as Icarus, 52 CHALLENGE 5, 16 (May-June 2009) (citing as a cause of the Icelandic crisis that, "Brokers criss-crossed the country offering cheap loans denominated in low-interest foreign currencies.”). See also, Nerijis Adomaitis, No Iceland Scenario Here, Baltic Leaders Say, REUTERS October 10, 2008, available at http://www.reuters.com/article/idUSLA30794620081010 (noting that debt-funded expansion and subsequent inability to refinance caused the banking collapse and quoting Lithuanian Prime Minister Gediminas 
Low interest rates in much of the developed world meant that investors were seeking opportunities to earn higher returns. As a European Central Bank study described it,

[s]ince the late-1990s, the global economy is characterized by two largely unprecedented phenomena. The first is the benign financial market environment, low long-term interest rates, low risk aversion, the hunt for yield, and the perceived abundance of global liquidity, all of which prevailed at least until the turmoil episode that hit global financial markets during the summer of 2007. The second is the widening of external imbalances, in particular the increasing current account deficit in the United States and the corresponding pick-up in current account surpluses of emerging Asian economies. ${ }^{97}$

As we describe in more detail in Section II, Iceland offered just such an opportunity between 2001 and 2007 because of the combination of the rise in value of the ISK against other currencies and the Icelandic central bank's promotion of increasingly higher interest rates.

As subsequent events revealed, monetary policy as practiced by the world's major central banks between 1990 and 2007 had three important defects. First, a successful managed monetary policy (compared to an automatic adjustment policy) requires an extraordinary degree of knowledge about the economy. ${ }^{98}$ During Alan Greenspan's tenure as head of the Federal Reserve in the United States, some thought that this problem had been solved by Greenspan's brilliance. ${ }^{99}$ However, as subsequent events made clear, and as Greenspan has himself since admitted, the Federal Reserve failed to accurately understand the impact of securitization of mortgages and low interest rates on the availability of credit to American homeowners, enabling the speculative housing bubble to grow for a considerable period unchecked by action by the Federal Reserve. ${ }^{100}$ More generally, Carmen Reinhart and Kenneth Rogoff have noted that "a belief in the invincibility of modern monetary institutions" was a key part of what they call a "this time is different syndrome" that misled both regulators and financial actors into believing that financial crises were a thing of the past. ${ }^{101}$ Our point is not that an actively managed monetary policy can never succeed under any circumstances but that both financial regulators and monetary policy authorities underestimated the economic risks associated with such policies while also

Kirkila claiming that large external debt was responsible for Iceland's economic downturn).

97 Thierry Bracke \& Michael Fidora, Global Liquidity Glut or Global Savings Glut? A Structured VAR Approach, European Central Bank Working Paper Series No. 9116 (June 2008) available at http://www.ecb.int/pub/pdf/scpwps/ecbwp911.pdf.

${ }^{98}$ William N. Butos, The Knowledge Problem Under Alternative Monetary Regimes, 5 CATO JOURNAL 849,867 (Winter 1986), available at http://www.cato.org/pubs/journal/cj5n3/cj5n3-11.pdf.

${ }^{99}$ See, e.g., Bob Woodward, MAESTRO: GREENSPAN’s FED AND THE AMERICAN BOOM (2000) (flattering biography of Greenspan stressing his brilliance); Edmund L. Andrews, The Doctrine Was Not to Have One, N.Y. TIMES (Aug. 26, 2005) ("At a hearing in July before the House Financial Services Committee, lawmakers from both parties showered him with so much praise that they began running out of accolades."). But see Michael Ashton, MAESTRO, MY Ass! xxii (2009) (Greenspan "was a poor, and especially shortsighted, Fed Chairman.”)

100 See Mark Felsenthal, Greenspan says didn't see subprime storm brewing, Reuters (Sept. 13, 2007) available at http://www.reuters.com/article/newsOne/idUSWBT00756820070913?pageNumber=1\&virtualBrandChannel=0 (quoting Greenspan that "While I was aware a lot of these practices [subprime mortgages] were going on, I had no notion of how significant they had become until very late [....]I really didn't get it until very late in 2005 and 2006. .")

${ }^{101}$ Carmen H. Reinhart \& Kenneth Rogoff, ThIS TIME IS DifFERENT: EIGHT CENTURIES OF FinANCIAL FOLLY 291 (2009). 
overestimating their abilities to effectively manage economies. (Concern over these problems has led some economists to recommend currency boards and other mechanisms to limit monetary authorities' discretion.) ${ }^{102}$ Belief in an almost omnipotent Federal Reserve obscured the dangers of risks caused by monetary authorities and fiscal policy alike. Neglecting such risks means that financial regulators have a significant blind spot, reducing the likelihood that they can adequately regulate.

Second, monetary policy in much of the world was geared to stimulating laggard economies. In particular, the Japanese, American, and European Union central banks all sought to promote economic growth through low interest rates during much of the 1990s and early 2000s, deliberately making debt inexpensive for both consumers and commercial borrowers throughout much of the world during this period. ${ }^{103}$ The low cost of borrowing led borrowers to favor debt over equity, as the cheap capital available in the form of debt was often more attractive than selling additional equity stakes. ${ }^{104}$ This drove investors to search more broadly for alternative investments offering a higher return, creating demand for investments abroad and in a broader range of investment types. ${ }^{105}$

\footnotetext{
${ }^{102}$ See, e.g., Steve H. Hanke, Lars Jonung \& Kurt Schuler, RUSSIAN CURRENCY AND FINANCE: A CURRENCY BOARD APPROACH TO REFORM (1993) (arguing for limiting discretion).

${ }^{103}$ Taylor, GETTING OfF TRACK, supra note 84, at 2 (noting that U.S. Federal Reserve gave "clear evidence of monetary excesses during the period leading up to the housing boom."); Bill Spindle, Debate Over Japan's Recovery to Go Before Central Bank -- Compromise Could Send Rates Lower in Exchange For Corporate Reforms, WALL ST. J., Feb. 26, 2001, at A18 (discussing how the Central Bank of Japan was under pressure to lower interest rates in order to aid the ailing economy and also mentioning the fact that the Central Bank of Japan lowered interest rates to nearly 0\% in 1999); James Norris, The Domino Effect, GlobAL InVESTOR, Sept. 2007, at 1 ("Like all big rivers, the current crisis is fed by a number of tributaries. ... [one] is the current interest rate regime in the US. Between May 2000 and August 2003, the US Fed Funds rate dropped from 6.5\% to just 1\%; the Bank of England cut base rates from $6 \%$ to $3.5 \%$ and the European Central Bank cut from $4.75 \%$ to $2 \%$. The policy was successful, says Steven Nicholls, vice-president and account manager at Pimco Europe, perhaps too successful. Cheap debt inflated a housing sector bubble in the US, UK and Spain, where lenders were increasingly innovative in providing mortgage solutions to borrowers.").
}

${ }^{104}$ See, e.g., Sewell Chan, Javier C. Hernandez, Bernanke Says Nation Must Take Action Soon To Shape Fiscal Future, NY TIMES, (Apr. 8, 2010), $\S \mathrm{B}$, at 3 (quoting the president of the Kansas City Fed claiming that artificially low interest rates create bubbles by encouraging debt over equity and promoting consumption over savings); Harry Koza, Minsky's Theories Hold Up, Yet Again, MAIL (Can.), Aug. 17, 2007, at B11 (describing how "Ponzi-like behaviour" thrives in the institutional market with cheap credit encouraging debt over equity issuance). This played an important role in Icelandic finance. Thorvaldsson, supra note 43, at 116-17, 134 (the "ever increasing use of debt financing" was key to liquidity of Icelandic banks in early 2000s and that Icelandic entrepreneur Jon Asgeir Johannesson "wouldn't buy a toothbrush unless he could borrow against it."). Thorvaldsson argues that Icelanders "have big appetite for debt", possibly because the word for "debt" is also the word for "luck" in Icelandic. Thorvaldsson, supra note 43, at 149.

${ }^{105}$ This search for return has been blamed for contributing to the popularity of Ponzi schemes like Bernard Madoff's and Alan Stanford's. Finance And Economics: In praise of Volatility; Buttonwood, Economist, Jan. 17, 2009, at 72 ("Low volatility was a large part of Bernard Madoff's appeal. He offered nice, smooth returns--such a contrast with the violent excesses of the stockmarket"); Robert Frank \& Tom Lauricella, 'Uncle Bernie' and His Angry Clients --Madoff Created Air Of Mystery, WALl ST. J., Dec. 20, 2008, at A1 ("The business, which started with a small circle of relatives and friends, was built on a simple premise: modest but steady returns regardless of market swings."); Miguel Bustillo \& Evan Perez, Bribes Alleged at Stanford's Hearing, WALL ST. J., June 26, 2009, at C3 ("[t]he Justice Department described how [Allen Stanford] and lieutenants used a high-volume sales operation and the lure of high-yielding certificates of deposit to attract money from 30,000 investors world-wide.”). 
Third, at the same time they were stimulating the world's economies, central banks were also playing an important role in regulating financial markets as lenders of last resort. ${ }^{106}$ In brief, the lender of last resort steps in to provide support for financial institutions experiencing withdrawals greater than the institutions can handle, prevent bank runs, and attempt to avoid disruption to the broader economy from the difficulties of individual financial institutions. ${ }^{107}$ The existence of a lender of last resort provides confidence in financial institutions at the price of inducing moral hazard, as those dealing with the financial institutions substitute reliance on the lender of last resort for their own due diligence in investigating the health of financial institutions. ${ }^{108}$ As financial institutions become multinational, the role of national lenders of last resort has become more complicated and difficult, since the same institution operating in multiple jurisdictions might call upon multiple lenders of last resort with respect to different aspects of its operations. ${ }^{109}$ Moreover, central banks' expansionary monetary policies increased their risks in their capacities as lenders of last resort but do not seem to have prompted regulatory measures to address the greater risks caused by their policies.

\section{Stimulative Fiscal Policies}

In addition to monetary policy, governments operate through fiscal policy. By varying spending and taxation levels, governments attempt to increase economic growth when it is "too low" and restrain it when growth is "too high." "While there is considerable academic debate about the appropriate fiscal policy for particular economic conditions, as well as the appropriateness of the use of fiscal policy measures for managing economies generally, ${ }^{111}$ these theoretical concerns appear to have given government policy makers few qualms about making use of fiscal policy measures to achieve their own economic policy and political goals. ${ }^{112}$

\footnotetext{
${ }^{106}$ In the United States, the Federal Reserve plays this role. Stephen R. Blau, The Federal Reserve and European Central Bank as Lenders-of-Last-Resort: Different Needles in their Compasses, 21 N.Y. INT'L L. REV. 39, 42 (2008) ("the Federal Reserve clearly has LOLR statutory authority" citing Pub. L. No. 73-1, § 403, 48 Stat. 1, 7 (codified as amended at 12 U.S.C. $\S 347$ c (2000))).

${ }^{107}$ See Frank Partnoy, Why Markets Crash and What Law Can Do About It, 61 U. PITT L. REV. 741, 757-84 (2000) (discussing role of lender of last resort).

${ }^{108}$ See Jonathan R. Macey \& Maureen O’Hara, Solving the Corporate Governance Problems of Banks: A Proposal, 120 BANKING L. J. 326, 328-29 (2003) (discussing how banks "foist[ed] some of their losses onto ... the federal taxpayers whose funds replenish the federal insurance fund when it is depleted").

${ }^{109}$ Joseph J. Norton, Trends in International Bank Supervision and the Basle Committee on Banking Supervision, 48 CONSUMER FIN. L.Q. Rep. 415, 417 (1994) (discussing complications of dealing with the cross-border lender of last resort problem).

${ }^{110}$ See David A. Moss, A Concise Guide to Macroeconomics 76-83 (2007).

${ }^{111}$ See e.g., Alan S. Blinder, The Case Against the Case Against Discretionary Fiscal Policy, THE Macroeconomics of Fiscal Policy 25 (Richard Kopcke, Geoffrey M. B. Tootell and Robert K. Triest, eds., 2006); Olivier Jean Blanchard, Comments on Blinder's "Case Against the Case Against Discretionary Fiscal Policy,” The Macroeconomics of Fiscal Policy 63 (Richard Kopcke, Geoffrey M. B. Tootell and Robert K. Triest, eds., 2006); Christopher A. Simms, Comments on Blinder's “Case Against the Case Against Discretionary Fiscal Policy,” The Macroeconomics of Fiscal Policy 69 (Richard Kopcke, Geoffrey M. B. Tootell and Robert K. Triest, eds., 2006).

${ }^{112}$ Xavier Debrun, David Hauner, \& Manmohan S. Kumar, Independent Fiscal Agencies, 23 J. ECON. SuRV. 44, 46, (February 2009) ("The literature has long recognized that policymakers in the fiscal domain act quite rationally, according to specific incentives, including reelection concerns, pressures from interest groups and constituencies, and the need to honour specific pledges or commitments.")
} 
During the first part of the 2000s, governments in the European Union, Japan, and the United States were generally engaged in fiscal policies intended to increase economic growth. ${ }^{113}$ Like the monetary policies pursued by the central banks, these policies sought to encourage business and consumer spending through spending and tax cuts, increasing government deficits. The United States, Japanese, and European governments engaged in significant deficit spending in the pre-crisis years: From 2001 to 2005, U.S. deficits averaged 3.46\% of GDP, Euro area deficits averaged 2.54\%, Japanese deficits averaged 6.84\%, and the OECD countries as a whole averaged $2.92 \% .{ }^{114}$ In Europe, EU members found that keeping to the original fiscal discipline to which they had agreed when creating the euro was too politically costly during a recession and even Germany, perhaps the most fiscally conservative member of the EU, exceeded the agreed deficit spending limits in the first part of the decade. ${ }^{115}$ In addition, the costs of the wars in Iraq and Afghanistan also boosted government spending, particularly in the United States. ${ }^{116}$ The result was a significant increase in government deficits, a deliberate choice of the governments in question as part of their fiscal policies. ${ }^{117}$ Most recently this contributed to the ongoing Greek

\footnotetext{
${ }^{113}$ See Toshiro Ihori \& Atsushi Nakamoto, Japan's Fiscal Policy \& Fiscal Reconstruction, Hitotsubashi University Research Unit for Statistical Analysis in Social Sciences Discussion Paper No. 99 (June 2005) available at http://ideas.repec.org/p/hst/hstdps/d05-99.html (describing fiscal stimulus of "aggressive public-spending policy" under Prime Ministers Obuchi and Mori; aggressive tax cuts under Prime Minister Koizumi "to copes with the unfavorable macro-economic situation"); Jurgen von Hagen, Fiscal Rules and Fiscal Performance in the European Union and Japan, MONETARY \& ECONOMIC STUDIES 25, 41 (March 2006) ("fiscal policy became more expansionary in EU all countries except Austria and Portugal after the start of EMU in 1999."); John D. Graham, Bush ON THE Home Front: DOMESTIC POLICY TRIUMPHS AND SETBACKS 27 (2010) ("The fiscal policies of George W. Bush were decidedly expansionary: multiple rounds of tax cuts combined with substantial increases in the rate of federal spending (both domestic and military).").

${ }^{114}$ Calculated from statistics in OECD, OECD FACTBOOK 2009: ECONOMIC, ENVIRONMENTAL AND SOCIAL STATISTICS (2009) available at http://lysander.sourceoecd.org/vl=10628001/cl=16/nw=1/rpsv/factbook2009/10/01/01/index.htm

115 See von Hagen, supra note 113, at 30 ("Somewhat ironically, Germany, the country that had pushed for tighter fiscal rules in EMU in the mid-1990s, was the second EMU member country and the first of the large member countries to violate the fiscal rules.").

${ }^{116}$ See Warwick McKibben, The United States Current Account Deficit and World Markets, Economic Scenarios (Issue 10) 2 (2005) ("From 2001 onwards there was a growing trend towards large public dis-saving in the United States brought about by a series of growing fiscal deficits. These deficits were due to a weak economy, lower tax rates and increased government pending, especially on the war in Iraq.").

${ }^{117}$ A further problem with fiscal policy as a tool for inducing economic growth is that deficit spending today implies higher taxes to fund repayment of the borrowed funds in the future. Under the rational expectations view of macroeconomic policy, people anticipate that temporary stimulative fiscal policies will lead to tax increases in the future as deficits increase. See Thomas J. Sargent, Rational Expectations, THE CONCISE ENCYCLOPEDIA OF ECONOMICS ( $2^{\text {nd }}$ ed. 2008) available at http://www.econlib.org/library/Enc/RationalExpectations.html ("The rational expectations version of the permanent income hypothesis has changed the way economists think about short-term stabilization policies (such as temporary tax cuts) designed to stimulate the economy. Keynesian economists once believed that tax cuts boost disposable income and thus cause people to consume more. But according to the permanent income model, temporary tax cuts have much less of an effect on consumption than Keynesians had thought. The reason is that people are basing their consumption decision on their wealth, not their current disposable income. Because temporary tax cuts are bound to be reversed, they have little or no effect on wealth, and therefore have little or no effect on consumption."). Whatever the merits of specific fiscal policies or the details of particular macroeconomic models, it seems beyond question that the "rational expectations revolution" of the 1970s identified a particularly thorny problem for fiscal policy enthusiasts. See Robert J. Barro, Are Government Bonds Net Worth?, 82 J. POL. ECON. 1095 (1974) (setting out the theory); Steven M. Sheffrin, RATIONAL ExPECTATIONS ix (1996)
} 
crisis, which resulted from Greek governments deliberately spending in excess of the levels agreed to amongst EU member states while using sophisticated financial instruments to hide the spending. 118

Expansionary fiscal policies are politically popular during economic downturns, since they enable politicians to claim credit for boosting economic activity. These policies also increases stresses within economies, increasing risks in ways generally ignored by financial market regulators focused on attempting to correct market failures. In addition, expansionary fiscal policies in one part of the interconnected global economy have an impact throughout the world economy. Expansionary fiscal policies generally thus contributed to the "search for alpha" around the globe. ${ }^{119}$

\section{Floating Exchange Rates}

Prior to World War I, all major world currencies were on the gold standard and exchange rates were generally stable, changing only if a government's commitment to maintaining its currency's convertibility became questionable. ${ }^{120}$ After much turmoil in the aftermath of World War I, the Great Depression, and World War II, exchange rates coalesced around the Bretton Woods system of fixed exchange rates and dollar convertibility into gold. ${ }^{121}$ However, since the 1971 collapse of the Bretton Woods system, freely floating exchange rates became the norm for most of the world's currencies. ${ }^{122}$ In a world of floating currencies, considerable gains are

(describing theory as "firmly embedded in the economist's theoretical tool kit"). Since today's debts must be repaid tomorrow, a prudent investor would anticipate higher taxes in the future and decrease consumption today to save for tomorrow's tax bill. Moreover, the theory itself suggests that raising taxes to repay the debt in the future will dampen future economic growth by reducing future expenditures. (Fiscal policy enthusiasts argue that gaining growth today is worth a penalty in the future, since today's growth can also fund increases in wealth that lead to higher incomes, reducing the size of tomorrow's tax increase.) See David N. Weil, Fiscal Policy, THE CONCISE ENCYCLOPEDIA OF ECONOMICS available at www.econlib.org/library/Enc/FiscalPolicy.html ("Expansionary fiscal policy will lead to higher output today, but will lower the natural rate of output below what it would have been in the future. Similarly, contractionary fiscal policy, though dampening the output level in the short run, will lead to higher output in the future."). As a result, fiscal stimuli both pump money into economies around the world, some of which eventually ended up in investment accounts seeking opportunities for investment, and increase demand for investment opportunities that could generate the returns necessary to pay the higher taxes that would come in the future to pay off these deficits.

${ }^{118}$ See Rebecca M. Nelson, Paul Belkin, \& Derek E. Mix, Congressional Research Service, Greece’s Debt Crisis: Overview, Policy Responses, and Implications 3-4 (2010); Elisa Martinuzzi, Greece’s Off-Market Swaps Added \$7.2 Billion to its Debt, Eurostat Reports, Bloomberg (Nov. 15, 2010) available at http://www.bloomberg.com/news/2010-11-15/eurostat-says-off-market-swaps-added-eu5-3-billion-to-greekdebt.html; Michael Bathon, Greece Hidden Debt, Goldman, Anglo Irish: Compliance, Bloomberg (Sept. 9, 2010) available at http:/www.bloomberg.com/news/2010-09-09/greece-s-hidden-debt-goldman-anglo-irish-avtovazcompliance.html.

119 The Icelandic government also pursued expansionary fiscal policies during the 1990s and early 2000s, as we describe in more detail later.

${ }^{120}$ Eichengreen, GLOBALIZING CAPITAL, supra note 55, at 73 (Under the pre-World War I gold standard, "[w] hen a country's exchange rate weakened, capital flowed in, supporting rather than undermining the central bank's efforts to defend convertibility, since currency traders were confident of the official commitment to hold the exchange rate within the gold points and therefore expected the currency's weakness to be reversed" and so currency values were maintained).

${ }^{121}$ Eichengreen, GLOBALIZING CAPITAL, supra note 55, at 91-92 (summarizing Bretton Woods system).

122 Eichengreen, GLOBALIZING CAPITAL, supra note 55, at 134-36 (describing movement to floating exchange rates). 
available from correct bets on currency movements; considerable losses are also possible from incorrect bets. ${ }^{123}$ For example, George Soros made \$1 billion in 1992 by betting against the British pound ${ }^{124}$ and Victor Niederhoffer's mutual fund's value collapsed in 1997 as a result of failed speculation in Asian currencies. ${ }^{125}$

While Soros-sized profits are available only by making large bets on the future movements of currencies, currency movements can also affect smaller investors. Investing in assets denominated in a currency increasing in value against one's own currency will yield an additional return, independent of the asset's performance in its own currency, as the same amount of the rising currency buys increasing amounts of the declining one. For those in an economy with an appreciating currency, borrowing in foreign currencies is made less expensive because a portion of the debt is repaid by the appreciation in the domestic currency. ${ }^{126}$ In particular, Icelandic firms that borrowed in foreign currencies and invested in Icelandic shares could profit from the rising currency.

Individuals also benefited. For example, if an Icelander borrowed $€ 100,000$ on January 1 , 2004, converted the money into ISK, held it in a bank account, and repaid the loan in euros on October 31, 2005 (the peak of the Icelandic currency), she would have earned $23.29 \%$ before interest costs and taxes just from the currency appreciation. ${ }^{127}$ If she used the euro-denominated loan to invest in real estate in Reykjavik, where prices appreciated rapidly (29\% from 2004 to $2005),{ }^{128}$ she would have grossed over $50 \%$ in under two years. Not surprisingly, many Icelanders took advantage of the appreciation of the ISK to borrow in foreign currencies. ${ }^{129}$

\footnotetext{
${ }^{123}$ Henry R. Zheng, Management of Lenders' Currency Exposure in Multicurrency Financings: Structural and Documentational Considerations, 22 LAW \& POL'Y INT'L BUS. 213, 259 (1991).

${ }^{124}$ Brendan Murphy, Finance: The Unifying Theme, THE ATLANTIC (July 1993) available at http://www.theatlantic.com/doc/199307/george-soros.
}

${ }^{125}$ See, e.g. James Altucher, Wealth Advisor: Ten Things I Learned Trading for Niederhoffer, Dow JONES FACTIVIA, February 23, 2008. ("Victor [Niederhoffer] was a top trader for George Soros before starting his own fund in the '90s and then writing the classic investment text 'Education of a Speculator.' He then suffered one of several blowups in his career when his fund crashed to zero while on the wrong side of a couple of bets during the Asian currency crisis in 1997. ...”); see also, Guillermo Parra-Bernal and Carolina Marcondes, Brazil's Fibria Q4 loss falls, to cut investments, Dow Jones FACTIVIA, February 26, 2010 (noting that two companies were driven to bankruptcy by incorrect bets on Brazilian currency).

${ }^{126}$ Boyes, supra note 4, at 89 ("the bankers actively sucked ordinary Icelanders into their system. How best to guard yourself against the rising cost of personal loans, indexed to the cost of living? You borrow in foreign currencies: as long as the krona stayed strong (and as long as theat hot money kept coming into the country), you couldn't go wrong if you bought your house or car, or paid for your holiday, with a loan denominated in Japanese yen and Swiss francs. It was the surest way to beat inflation.")

${ }^{127}$ Calculated using Oanda currency converter, http:/www.oanda.com/currency/historical-rates/.

${ }^{128}$ Rosmundar Gudnason \& Gudrun Jonsdottir, House Price Index, Market Prices and Flow of Services Method, Paper 20, OECD-IMF Workshop, Real Estate Price Indexes, Paris 7 (2006) available at www.oecd.org/dataoecd/2/42/37583740.pdf. Although we selected the dates in this example to show the maximum effect, it captures the sense of growing wealth Icelanders with foreign currency loans and Icelandic real estate investments felt in 2000-2005. The ISK began to fall in November 2005, partially recovered in early 2007, and then began a long slide in October 2007. See Oanda calculator, supra note 127.

${ }^{129}$ Boyes, supra note 4, at 5 (Icelanders used "complex loan packages involving Japanese yen, Swiss francs, and euros" to fund consumption during boom; took on "record amounts of debt"). 
For most of the twentieth century, there were significant transactions costs involved in making investments in foreign currencies, putting such investments out of the reach of ordinary people. The decline in transactions costs due to the combination of falling telecommunications costs, opening of capital markets, and innovation in financial products (e.g. mutual funds specializing in investments in foreign markets) opened international investing to an increasing share of the small investor market. Buying shares on the Icelandic stock exchange, bonds issued by Icelandic banks or other "Icelandic" financial assets during the early 2000s was quite easy for non-residents of Iceland. For example, the speculative position of foreign investors in such assets or contracts at the height of the Icelandic boom was around 1000-1200 billion ISK or between 70-80 percent of the country's GDP. ${ }^{130}$ In particular, European private investors - often referred to as "Belgian dentists" - were regularly investing in ISK-denominated assets during the boom. ${ }^{131}$

Open economies with fluctuating exchange rates present a quite different set of investment risks than do less open ones with fixed exchange rates. Such risks do not necessarily mean that either openness or floating exchange rates are inappropriate policies. (Neither of us thinks they are, although others have so argued. ${ }^{132}$ ) They do mean that financial regulators need to take into account both a country's domestic fiscal policies and the impact of other countries' fiscal policies when evaluating risks, complicating regulators' tasks. For example, borrowers with debts denominated in foreign currencies are subject to additional risks compared to borrowers whose debts are denominated in domestic currency and so might have higher default rates.

In retrospect, it does not appear that all of those making multi-currency investments fully appreciated the risks those transactions posed. This was particularly true for individuals and institutions investing in ISK-related transactions, because the small size of the Icelandic economy meant the ISK was particularly susceptible to large changes in value. Moreover, the credit rating agencies rating Icelandic banks and firms and the regulators both in Iceland and elsewhere regulating the activities of the Icelandic banks at home and abroad also appear to have paid too little attention to exchange-rate risk. It is not just hindsight with respect to Iceland that enables us to make this criticism: a key feature of the post-Bretton Woods era has been much larger volatility in exchange rates than under the Bretton Woods system. ${ }^{133}$ Yet the risks appear not to have been sufficiently widely recognized.

\footnotetext{
${ }^{130}$ Jonsson, supra note 24, at 192 ("Prior to the banks' demise, the speculative position of foreigners in Icelandic interest-yielding assets or derivative contracts was around ISK 1,000 billion to 1,200 billion: the equivalent of 80100 percent of the M3 money supply, or 70 to 80 percent of the GDP.’')

${ }^{131}$ Jonsson, supra note 24, at 71 ("The glacier bonds would then be sold to retail clients - Belgian dentists, Italian widows, etc. - who had a very vague idea of what exchange rate meant, but who were delighted to receive high interest with AAA rating. The glacier bond issuing began in August of 2005 and became quite ferocious. It seemed that all the "Belgian dentists" and "Italian widows" of Europe were eager to become the beneficiaries of the high Icelandic interest rates.”) See alsoThorvaldsson, supra note 43, at 152.

132 See Mahathir Bin Mohamad, The Future of Asia, $6^{\text {th }}$ Nikkei Shimbun International Conference on 'The Future of Asia', Tokyo, 9 June 2000 (criticizing floating exchange rates and advocating fixed exchange rate regimes). See also Atish R. Ghosh, Anne-Marie Gulde, \& Holger C. Wolf, EXCHANGE RATE REGIMES: CHOICES AND CONSEQUENCES 1 (2003) ("Does the choice of exchange rate regime matter? Few questions in international economics have sparked as much debate and yielded as little consensus.")

${ }^{133}$ See, e.g., Robert P. Flood \& Andrew K. Rose, Understanding Exchange Rate Volatility without the Contrivance of Macroeconomics, 109 THE ECONOMIC JOURNAL F660, F666-F667 (1999) (noting that it is "undisputed" that
} 
More generally, it does not appear that financial regulators or credit rating agencies in any of the major economies were paying much attention to the challenges floating exchange rates pose for financial institutions and investors. Failing to assess the risks properly led to underestimation of the risks faced by the Icelandic banks' and firms' exposure to swings in the exchange rates. Keeping up with firms' exposure to exchange rate risk is challenging for either investors or regulators, since firms operating across borders must conduct a wide range of potential exchange rate transactions regularly. Our point is not that more regulation is necessarily the appropriate response but simply that floating exchange rates make it harder to regulate multinational firms and transactions by introducing new sources of risk.

\section{E. Lagging Regulatory Institutions}

In times of rapid economic change, regulators struggle to keep up with a shifting landscape. New financial instruments, new patterns of capital flows, and changes in demand for particular types of costs also pose problems for regulators. For example, the rise of hedge funds caught U.S. and EU regulators off guard, creating a vast class of investment capital whose defining characteristic was its comparatively unregulated nature. ${ }^{134}$ Serious regulatory attention did not appear until well after hedge funds had become a significant part of the financial system. ${ }^{135}$ Similarly, serious concerns over what we now recognize as global systemic risks appeared among regulators only after the global financial crisis demonstrated that such risks were serious problems. ${ }^{136}$ Regulators thus have a problem keeping up with change. Regardless of how desirable any particular regulatory measures are, this is a serious problem with regulatory institutions and regulatory lags are particularly problematic in rapidly changing areas. This proved true of regulators regardless of their regulatory approach. For example, U.K. financial regulators had a single primary regulator with a principles-based approach while U.S. regulators

floating exchange rate volatility increased by an order of magnitude after the collapse of Bretton Woods and citing Michael M. Mussa, Nominal Exchange Rate Regimes and the Behaviour of the Real Exchange Rate, CARNEGIEROCHESTER SERIES ON PUBLIC POLICY 117-213 (1986), as having established it.). We think the documentation of this effect from so long before the problem is evidence that it was well understood.

${ }^{134}$ See Houman B. Shadab, The Law \& Economics of Hedge Funds, 6 BERKELEY Bus. L. J. 240, 242 (2009) (“A hedge fund is a private investment company that is not subject to the full range of restrictions on investment activities and disclosure obligations imposed by federal securities laws, that compensates management in part with a fee based on annual profits, and typically engages in the active trading of financial instruments.").

${ }^{135}$ See, e.g., Andrew J. Donohue, Director, Division of Investment Management, Securities and Exchange Commission, "Regulating Hedge Funds and Other Private Investment Pools," Before the Subcommittee on Securities, Insurance, and Investment, Senate Committee on Banking, Housing, and Urban Affairs 2 (July 15, 2009) available at http://banking.senate.gov/public/index.cfm?FuseAction=Hearings. Testimony\&Hearing_ID=b4b5348bba91-4512-bca2-bf45b2e5fbde\&Witness ID=e25a4d16-d909-488c-b670-07231f9a4c7e ("The securities laws have not kept pace with the growth and market significance of hedge funds and other private funds and, as a result, the [Securities and Exchange] Commission has very limited oversight authority over these vehicles.") We are not advocating increased regulation of hedge funds, merely noting that their growth exemplifies the problems regulators have in adapting to a fast changing industry.

${ }^{136}$ See Steven L. Schwarcz, Systemic Risk, 97 GEO. L. J. 193, 247-48 (2008) (asserting it was "the first major work of legal scholarship on systemic risk" and noting that "[e]conomists and other scholars historically have tended to think of systemic risk in terms of financial institutions such as banks, and only infrequently in terms of financial markets") 
favored rule-based approaches and divided responsibilities among multiple, competing regulators. ${ }^{137}$ Neither approach anticipated or prevented the crisis.

Regulators face three problems in adapting to change. First, if we believe regulation is best accomplished within a framework of laws and regulations that give the regulated clear guidance and advance notice, updating a regulatory system is itself a time- and resourceintensive task. ${ }^{138}$ Second, regulators who want to adapt need information on which to base their decisions and collecting and analyzing such information is neither simple nor cheap. ${ }^{139}$ Third, once they have collected and analyzed information and drafted new legislation or regulations, they must navigate through interest group politics to have those drafts enacted. ${ }^{140}$ Regulatory lags mean that even assertive regulators with considerable powers are often well behind events, making reliance on them to safeguard markets problematic. Of course, there are steps that can improve any regulator's performance - although there is often disagreement about what those steps are ${ }^{141}$ - but such lags are inevitable, if only as a result of due process protections that require regulators to give advance notice of changes in rules.

Regulatory lags are particularly serious in financial regulation because a defining feature of the financial landscape is innovation. Nobel laureate Merton Miller noted this in a 1986 article, concluding that "the word revolution is entirely appropriate for describing the changes in financial institutions and instruments that have occurred" between 1966 and 1986. ${ }^{142}$ About the same time, James van Horne concluded "One of the bedrocks of our financial system is financial innovation, the life blood of efficient and responsive capital markets." ${ }^{\text {,43 }}$ Somewhat remarkably,

\footnotetext{
${ }^{137}$ Dalvinder Singh, BANKING REgULATION OF THE UK AND US FINANCIAL MARKETS 1 (2007) (comparing UK “consolidated system of regulation" to U.S. "unique regulatory structure, with a number of 'bank' regulators in addition to securities and insurance regulators.").

${ }^{138}$ The demands of process prompted a literature on regulatory ossification with respect to the U.S. Occupational Safety and Health Administration. See Thomas O. McGarity, The Courts and the Ossification of Rulemaking: A Response to Professor Seideneld, 75 TEX. L. REV. 525 (1997); Thomas O. McGarity, Some Thoughts on “Deossifying” the Rulemaking Process, 41 DukE L.J. 1385 (1992). It also prompted efforts to speed development of rules through alternative forms of rulemaking. See Andrew P. Morriss, Bruce Yandle, \& Andrew Dorchak, REGULATION BY LITIGATION 43-47 (2008) (summarizing efforts to develop regulation-by-negotiation to speed rulemaking).

${ }^{139}$ See generally, Daniel K. Tarullo, EQuiPPING FINANCIAL REGUlATORS WiTH THE TOOLS NECESSARY TO MONITOR SYSTEMIC RISK, http://www.federalreserve.gov/newsevents/testimony/tarullo20100212a.htm, February 12, 2002. See also, Thomas Sowell, KNOWLEDGE AND DECISIONS 26 (1996) ("In reality, knowledge can be enormously costly, and is often widely scattered in uneven fragments, too small to be individually usable in decision making. The communication and coordination of these scattered fragments of knowledge is one of the basic problems - perhaps the basic problem - of any society, as well as its constituent institutions and relationships."); 13 ("Because the powers of the higher decision-making units include the power to require transmission of knowledge, the persistence of knowledge advantages by the subordinate units implies either an impossibility or a prohibitive cost to the higher unit of independently acquiring the same knowledge as a check against the accuracy of the knowledge transmitted by the subordinate unit. In short, there are differences in their respective costs of acquiring knowledge.")

140 See Morriss, Yandle, \& Dorchak, supra note 138, at 22-27 (describing constraints involved in regulation).

${ }^{141}$ See Morriss, Yandle, \& Dorchak, supra note 138, at 43-47 (describing heated controversy over whether negotiated rulemaking is an improvement in process over notice and comment rulemaking).

${ }^{142}$ Merton H. Miller, Financial Innovation: The Last Twenty Years and the Next, 21 J. FIN. \& QUANT. ANALYSIS 459, 467 (December 1986).

${ }^{143}$ James Van Horne, Of Financial Innovations and Excesses, 40 J. OF FIN. 621, 621 (1985).
} 
this innovation has been subjected to relatively little empirical study. ${ }^{144}$ The key point is that it should not have been news in the 2000s that finance changed rapidly, yet regulators continued (and still continue) to operate with significant lags.

\section{F. The Impact of Context}

The factors outlined above played a significant role in the Icelandic crisis, as we describe below in the next section, as well as in the subsequent Greek, Irish, Portuguese, and Spanish crises, and in the larger global crisis. They magnify the scale of policy errors and can make orthodox policy steps have counterproductive results. Where a financial system lacks sufficient feedback mechanisms to adjust in time, this can be disastrous - as it was in Iceland.

As a small, open economy, Iceland was more vulnerable to changes in the world economy than are large, open economies like Britain or the United States or large, semi-closed economies like China. But not only is Iceland not the only small, open economy at risk (Latvia and Estonia are just the most frequently mentioned among the dozens of small open economies in the world today), ${ }^{145}$ the factors described have an impact on the larger economies as well. More than one observer has worried that London is Reykjavik-on-Thames ${ }^{146}$ and Fortune headlined a 2010 article on the U.S. economy "Welcome to the United States of Iceland."

As we have outlined above, in important ways, London is "Reykjavik-on-Thames" and the United States is the "United States of Iceland." As we outlined above, all economies are operating in an environment that is qualitatively different from prior experience. Economies are more open than they have been since World War I, that openness includes floating exchange rates that differentiate today from the pre-World War I period, and the pace of financial innovation is both rapid and an inherent part of a global financial system where not even the largest economy's financial regulator can effectively regulate all aspects of finance. Our world includes political leaders and central bankers who have largely been freed of the constraints earlier monetary systems imposed. No longer does the gold standard or the Bretton Woods system restrain political authorities from engaging in massive fiscal stimuli nor - as the pre-crisis floods of liquidity and the post-crisis responses of the ECB and Federal Reserve demonstrate are there any actions that central bankers appear to be categorically unwilling to take. In a world where fiscal and monetary discipline has become voluntary, financial regulation cannot be premised on a stable financial environment.

Policymakers around the world need to be concerned that the global economy's greater openness and the loosening of the institutional constraints on fiscal and monetary policy makers means that financial regulators must pay attention to fiscal and monetary policy as well as to the

\footnotetext{
${ }^{144}$ W. Scott Frame \& Lawrence J. White, Empirical Studies of Financial Innovation: Lots of Talk, Little Action, 42 J. ECON. LIT. 116 (2004).

${ }^{145}$ See, e.g., Boyes, supra note 4, at 14 (noting parallels to Baltic nations).

${ }^{146}$ See, e.g., Reykjavik-on-Thames, The Economist (Jan. 29, 2009) available at http://www.economist.com/node/13021969?story id=13021969; Fraser Nelson, Reykjavik on Thames, Coffee House: The Spectator Blog (Nov. 22, 2008) available at http://www.spectator.co.uk/coffeehouse/3031231/reykjavikon-thames.thtml; Paul Murphy, Reykjavik-on-Thames, ft.com/alphaville (Nov. 14, 2008) available at http://ftalphaville.ft.com/blog/2008/11/14/18243/reykjavik-on-thames/.

${ }^{147}$ Welcome to the United States of Iceland, Fortune (March 10, 2010) available at http://money.cnn.com/2010/03/10/news/international/iceland debt.fortune/index.htm
} 
details of banking capital requirements and deposit insurance. Despite being a small economy, Iceland's crisis has had an impact with which the world financial system has had difficulty coping. Imagining the consequences if the next crisis involves a larger economy - as the current sequential crises in southern Europe and Ireland are forcing us to do - should be considerable motivation for getting the lessons of the Icelandic crisis right. Virtually everyone has a theory to explain the global financial crisis and our comparative advantage is not to offer yet another one. ${ }^{148}$ What we can offer is a perspective that focuses attention on areas that policymakers have ignored in their response to the Icelandic crisis. We now turn to analyzing what happened in Iceland, which presents in a microcosm the impacts of the factors we described above.

\section{The Icelandic Crisis}

Iceland's financial crisis, like the ongoing global financial crisis, cannot be understood ahistorically. Context matters. We therefore begin with a brief history of the Icelandic economy, highlighting how Iceland came to experience its economic boom during the 1990s and early 2000s. We then describe the boom, the "Glacier crisis" that preceded the overall crash, the collapse in 2007, and the aftermath of the collapse.

\section{A. Before the Boom}

Iceland entered the twentieth century in the midst of a transformation from a poor, isolated, colony of Denmark into a modern economy. The repeal in the mid-19th century of restrictive Danish laws which had forbidden Icelanders from residing on the coast, fishing, and engaging in trade created the Icelandic fishing industry. ${ }^{149}$ More importantly, the repeal transformed a closed, barter economy into a more open one with modern banking institutions. ${ }^{150}$ As was the case throughout the North Atlantic and European economies, however, Iceland reversed course on financial openness during World War I and the degree of state involvement in the economy expanded considerably. ${ }^{151}$ The combination of wartime inflation and loss of access to international capital markets following Iceland's 1918 separation from Denmark (becoming an independent kingdom connected to Denmark through a personal union with the Danish king) ${ }^{152}$ led the Althingi (Icelandic parliament) to restructure the banking industry after the war, granting the state-owned Landsbanki exclusive rights to issue currency in 1928, creating a central bank

\footnotetext{
148 See Reinhart \& Rogoff, supra note 101 (summarizing theorizing about why each crisis is different).

149 Thrainn Eggertsson and Tryggvi Thor Herbertsson, Evolution of Financial Institutions: Iceland's Path from Repression to Eruption. Institute of Economic Studies Working Paper Series, University of Iceland, December 2005, at 5-6. See also Thrainn Eggertsson, No Experiments, Monumental Disasters. Why it Took a Thousand Years to Develop A Specialized Fishing Industry in Iceland, 30 J. ECON. BEHAVIOR \& ORG.1 (1996).

${ }^{150}$ The first two commercial banks in the country's history were founded; the state owned Landsbanki in 1886, and the privately owned (by Danish investors) Islandsbanki in 1904, which had the right to issue notes and coins as a lawful medium of exchange. Eggertsson \& Herbertsson, supra note 149, at 4-6. See also Jónsson, supra note 24, at 19-31. On the role of access to a capital market allowed the fishing industry to modernize fishing fleet in the first two decades of the 20th century, see Eggertsson \& Herbertsson, supra, at 3. Jónsson, supra, at 22-23

${ }^{151}$ Eggertsson \& Herbertsson, supra note 149, at 7 ("Various restrictive measures that had been introduced during the war were continued and expanded when peace arrived."). See also Jónsson, supra note 24, at 25.

152 Jónsson, supra note 24, at 26 ("Iceland had lost most of its access to foreign financial markets when it moved to separate from Denmark in 1918.”).
} 
division within the that bank, ${ }^{153}$ instituting capital controls, ${ }^{154}$ founding a fisheries bank (Útvegsbanki) and an agricultural bank (Búnaðarbanki). ${ }^{155}$

The cumulative effect of these measures was to give the state firm control of the financial sector, which continued until the late 1990s. Not surprisingly, Icleandic political parties dominated the appointment of the banks' board members and the banks' highest ranking officials were part of the political elite. ${ }^{156}$ While over time a few private banks were founded, including small savings banks and banks established by corporate interests groups dissatisfied with the agricultural and fisheries interests' dominance of the state banks through their political power, ${ }^{157}$ the state remained firmly in control of the nation's financial system. As Eggertsson and Herbertsson concluded, this "repressed financial system was seriously dysfunctional in terms of standard economic criteria but nonetheless for a long while the system was politically stable." "158

State involvement in the economy went considerably beyond finance, however. State monopolies controlled fish production and dairies; high tariffs and state-allocated loans supported industries ("furniture, shoes, margarine and sweets") that would not otherwise have existed in Iceland. ${ }^{159}$ "Imports were regulated, trade with foreign currency was monopolized by state-owned banks, and loan capital was largely distributed by state-regulated funds." 160 Iceland remained relatively poor with little economic activity beyond fishing and agriculture into the 1930s. ${ }^{161}$ Karlsson's history illustrates the pre-World War II economy with an anecdote about a farmer's son who returned home in 1925 with a wheelbarrow, only to be told by his father "This is no doubt a good tool for those who know how to use it."162

German occupation of Denmark and Allied occupation of Iceland during World War II severed Iceland's economic ties to Denmark. The founding of the Republic of Iceland in 1944 ended the political ties as well. Although its economy remained heavily state-controlled, the new

\footnotetext{
153 Jónsson, supra note 24, at 23, 25 (by "1919 the outstanding money note issues had increased by a factor of seven and prices in Iceland had more than quadrupled."). See also Eggertsson \& Herbertsson at 7 ("The arrangement to let private bank, Íslandsbanki, issue money in co-operation with the country's parliament had not been entirely successful.") Islandsbanki struggled in the 1920s under a new regime, and partly due to difficulties in the fishing industry and the effects of the Great Depression Íslandsbanki closed shop on February 2, 1930. Jónsson, supra, at 26; Eggertsson \& Herbertsson, supra note 149, at 7.

${ }^{154}$ Jónsson, supra note 24,at 26 (in 1931 "Landsbanki petitioned the Althing for capital controls, which were instantly enacted, and which remained in place until 1994.”).

${ }^{155}$ Eggertsson \& Herbertsson, supra note 149, at 7.

${ }^{156}$ Eggertsson \& Herbertsson, supra note 149, at 10-11; Jónsson, at 26-27; Thorvaldsson, supra note 43, at 149 (prior to 1990s,"knowing a well-connected politician was often the only way to get a sizeable loan").

157 These included Idnadarbankinn in 1953 (bank of industries), Verslunarbankinn in 1961 (bank of commerce) and Althydubankinn in 1971 (bank of the labour unions). Jonsson, supra note 24, at 27. Eggertsson \& Herbertsson, supra note 149, 7.

${ }^{158}$ Eggertsson \& Herbertsson, supra note 149, at 10.

${ }^{159}$ Karlsson, supra note 6 , at 311

${ }^{160}$ Karlsson, supra note 6 , at 312.

161 Thorvaldsson, supra note 43, at 18.

${ }^{162}$ Karlsson, supra note 6, at 291.
} 
republic began in a strong economic position. ${ }^{163}$ Relative to the rest of Europe, Iceland not only suffered little damage to its territory during the war but had experienced considerable economic growth from Allied spending on air and naval bases during the war. ${ }^{164}$ These transfer payments continued after the war, with Iceland receiving more financial aid per capita under the Marshall plan than any other European nation, ${ }^{165}$ as its strategic location between North America and Europe astride vital shipping lanes led the United States to spend heavily in developing the sprawling Keflavik air base, starting in 1941. ${ }^{166}$ By the end of the war Icelanders held significant foreign exchange in foreign banks from their wartime earnings, since ownernship of foreign exchange was permitted only to banks within Iceland. ${ }^{167}$

The now fully independent Iceland sought advice from a committee of economists on economic policy. ${ }^{168}$ Reflecting the post-war Keynsian consensus, these economists emphasized the need for active management of the economy by the government ${ }^{169}$ with the result that in Iceland, "interference and planning were the norm." 170 In particular, the committee concluded that the strength of the new currency (the krona) had led to an excessive inflow of goods right after the war and caused an investment boom, especially in construction. ${ }^{171}$ Further, the committee noted that many private entrepreneurs had transferred their wartime earnings out of the country and were holding foreign currency abroad. ${ }^{172}$ To prevent additional capital outflows, the experts advised the government to introduce more stringent capital controls and other measures to manage the post-war boom, advice the government accepted. ${ }^{173}$

\footnotetext{
${ }^{163}$ Karlsson, supra note 6, at 319-323 (describing formation of Republic). Iceland was granted a sovereign status under the Danish rule on December 1, 1918 but had been a under a foreign rule since 1262, first Norway, then Denmark.
}

${ }^{164}$ Boyes, supra note 4, at 21 ("By the end of the war, thanks to the investment of U.S. forces, Iceland was a creditor nation, with strong currency reserves, and a good balance of trade");

${ }^{165}$ Karlsson, supra note 6, at 337 (Iceland received "almost twice as much in direct help per capita as any other country.");

${ }^{166}$ Boyes, supra note 4, at 21, 23-24, 78-79, 132 (discussing Keflavik, noting it provided 18\% of Iceland's foreign earnings by 1955, noting spending from base contributed to inflation in Iceland, quoting Icelanders as calling World War II "the blessed war" because of economic benefits to Iceland); Karlsson, supra note 6, at 317-318 (describing negotiations over Keflavik).

${ }^{167}$ Karlsson, supra note 6 , at 317.

168 Jakob F. Ásgeirsson, A NATION UNDER RESTRAINT (Icelandic: Pjóð í hafti) (1988, 2008) at 169-181.

169 Ásgeirsson, supra note 168, at 174-181

${ }^{170}$ Boyes, supra note 4, at 37 (quoting economist Thorvaldur Gyfasson).

171 Ásgeirsson, supra note 168, at 171 (citing the report of the committee). Wartime spending by the Allies during a period when consumer goods had been in short supply had created substantial currency reserves, which Icelanders used to buy imported goods after the war. Id. at 168 (citing a report of Olafur Tomasson and Johannes Nordal (former Governor of the Central Bank of Iceland). The committee concluded that post-war spending of these reserves on both imports and investment within Iceland (e.g. construction) had created a labor shortage, with the resulting high wages luring workers from Denmark and the Faraoe Islands to come to Iceland. Id. at 172.

\footnotetext{
172 Ásgeirsson, supra note 168, at 173.

173 Ásgeirsson, supra note 168, at 181. See also id. at 168 (citing the report of Tomasson and Nordal).
} 
The first decades of the post-War managed Icelandic economy produced steady economic growth; Iceland averaged $4.5 \%$ growth in the $1950 \mathrm{~s}, 4.6 \%$ in the $1960 \mathrm{~s}$ and $6.3 \%$ in the $1970 \mathrm{~s} .{ }^{174}$ This growth derived from two sources. First, Iceland continued to receive significant resource transfers via American spending on the Keflavik airbase. ${ }^{175}$ Second, Iceland's fisheries constituted a major source of natural wealth, with fish accounting for approximately $90 \%$ of product exports through the late 1960s, for example. ${ }^{176}$ (After the herring stock collapse in 1967, the fisheries share fell sharply.) ${ }^{177}$ The expansion of the Icelandic fishing zone from 4 miles in 1952 to 200 miles in 1975 increased fisheries income further. These advantages provided Iceland with a source of foreign exchange through the $1970 \mathrm{~s} .{ }^{178}$ Reliance on these sources of funds also contributed to a less attractive feature of the post-war Icelandic economy: inflation. The combination of expansionary fiscal policy and foreign exchange earnings created inflationary pressures. $^{179}$

\footnotetext{
${ }^{174}$ Report of the Special Investigation Commission to Althingi (SIC), Reykjavik, April 12, 2010, chapter 4.3.3, at 83-84 (hereafter "SIC's report"). The Special Investigation Commission (SIC) delivered its report to Althingi on April 12, 2010. The Commission was established by Act No. 142/2008 by Althingi, the Icelandic Parliament, in December 2008, to investigate and analyse the processes leading to the collapse of the three main banks in Iceland. Members of the Commission were Supreme Court Judge, Mr. Páll Hreinsson (now serving as a Judge to the EFTA Court in Luxembourg), Parliamentary Ombudsman of Iceland, Mr. Tryggvi Gunnarsson, and Mrs. Sigríður Benediktsdóttir Ph.D., lecturer and associate chair at Yale University, USA.
}

${ }^{175}$ Helgi Skúli Kjartansson, Iceland in the $20^{\text {th }}$ Century (Icelandic: Ísland á 20. öld), Sögufélag, Reykjavík 2002, at 276 (notes that between 1950-1956 the Marshall aid and US military spending in Iceland combined represented around $20 \%$ of the economy's foreign currency revenues. ) US military spending represented around $5-8 \%$ of the economy's foreign currency revenues from 1970 into the mid1990s and remained between 3-5\% until the US Military withdrew its forces, Source: Central Bank of Iceland. .

${ }^{176}$ Karlsson, supra note 6, at 358.

${ }^{177}$ See: http://www.fisheries.is/economy/fisheries-impacts/export/ • Ragnar Arnason \& Sveinn Agnarsson, Fisheries as Pillar of the Icelandic Economy (Icelandic: Sjávarútvegur sem grunnatvinnuvegur á Íslandi.), Fjármálatíðindi, Volume 52, Issue 2, 2005, p. 14-35.

${ }^{178}$ Arnason \& Agnarsson, supra note 177, at 18.

${ }^{179}$ SIC's report, supra note 174, chapter 4.3.3, at 78 ("[f]or half a century, 1940-90, inflation characterized the Icelandic economy more than anything else,”). See also Karlsson, supra note 6, at 349 . The collapse of the herring fishery in the late 1960s from overfishing damaged Iceland's export income. CITE: The troubled 70s and the collapse of herring fisheries. Regular conflicts with Britain over fishing rights led to the 1975-76 "Third Cod War . Although victorious in evicting British fishermen from its territorial waters, Iceland continued to overexploit cod and other fish stocks in the 1970s, experiencing all of the problems traditionally associated with open access resources. See Gunther Hellmann \& Benjamin Herborth, Fishing in the Mild West: Democratic Peace and Militarised Interstate Disputes in the Transatlantic Community, 34 REV. OF INT'L STUD. 481, 485-487 (2008) (analyzing military disputes between democracies from the perspective of fishery disputes with an emphasis on the "cod wars" between Iceland and Britain and also the "turbot war" between Canada and Spain); see also Iceland; Fish Slices, ECONOMIST, Nov. 22, 1975, at 55 (describing the circumstances at the height of the last cod war and diplomatic attempts to avoid another); Sea law; Watery War Outlook, ECONOMIST, May 31, 1975, at 37 (discussing the end of the last compromise deal between Iceland and Britain and Iceland's intentions to claim more fishing waters before 1975 ends); Boyes, supra note 4, at 131 ("Iceland won all three Cod Wars; that is, it fought for and defended its expanded fishing limits, and by embarrassing Britain in various diplomatic forums, it won some international support.") See also Boyes, supra, at 130-1 (claiming modern Icelandic entrepreneurs "influenced" by Third Cod War in attitudes toward Britain); Karlsson, supra note 6, at 344-347 (describing three cod wars and concluding that third Cod War brought about a "complete victory" in "Iceland's struggle for independence where the wet part of its territory was concerned."). Kjartansson, supra note 175, at 368 (describing attempts by the official 
In many respects, Iceland's post-war economic policies were not dissimilar to those in Britain and many other Western European nations where the influx of Marshall Plan money into Europe fueled fears of inflation; ${ }^{180}$ governments' memories of the unemployment that followed World War I drove them to restrict capital movements in an effort to boost domestic investment; ${ }^{181}$ and post-war social democratic governments across Europe used controls as part of their efforts to manage their economies. ${ }^{182}$ Iceland also embarked on a Nordic model social welfare state after the war, creating education, health, pension, unemployment, and other benefits at a level comparable to, if not quite as generous as, the other Nordic states. ${ }^{183}$

However, many of the economies in western Europe differed from Iceland as they combined these restrictive measures with a parallel process of market-opening, first through the European Steel and Coal Community formed by the Treaty of Paris in $1950^{184}$ and then the European Economic Community, which gradually expanded markets for continental European firms. ${ }^{185}$ Iceland did not participate in this initial economic opening ${ }^{186}$ but opted to maintain a more planned economy and degree of economic isolation, such that even in the 1980s Iceland could be characterized as "still a controlled, almost socialist society with strange, old-fashioned customs." 187 Iceland took some steps toward opening its economy, joining the European Free Trade Association (EFTA) in 1970. ${ }^{188}$ These measures did not signficantly reduce the level of state involvement in the economy, however.

Marine Research Institute in 1975 to limit the fishing activity, based on its "black report" on the state of the cod stock and subsequent policy initiatives to prevent overexploitation of the marine resource.)

${ }^{180}$ John Killick, The United StATES AND EUROPEAN RECONSTRUCTION 99-100 (2000) (describing inflationary post-war environment).

${ }^{181}$ Eichengreen, GLOBALIZING CAPITAL, supra note 55, at 93 (linking retention of controls in 1950s to commitment to full employment policy).

182 John B. Goodman \& Louis W. Pauly, The Obsolescence of Capital Controls?: Economic Management in an Age of Global Markets, 46 WORLD POLITICS 50, 79 (1993) ("In the early years of the postwar period, governments relied on controls over short-term capital movements for one fundamental purpose - to provide autonomy without sacrificing the benefits of economic interdependence. Controls were a shield that helped deflect the blows of international competition and ameliorate its domestic political effects.").

${ }^{183}$ Kjartansson, supra note 175, at 402-410 (describing the birth and development of the welfare state in Iceland after the war), at 409 (noting that public expenditure on health care increased substantially in post-war Iceland amounting in 1988 to $7 \%$ of GDP, with expenditure on social protection adding substantially to those numbers, and while these figures were not high in comparison with other Nordics states, they were perceived in Iceland as staggering.) From 1980 to 2008 social protection expenditure tripled in real terms and grew as part of GDP from 5,7\% to 8,9\%. Statistics Iceland, Social Protection Expenditure 2008, Statistical Series (October 2009).

${ }^{184}$ Treaty Establishing the European Coal and Steel Community, Apr. 18, 1951, 261 U.N.T.S. 140.

185 See Herman van der Wee, Prosperity AND UpheAval: THE World ECONOMY, 1945-1980 377 (1986) (noting trade between EEC countries quadrupled from 1958 to 1969).

186 Treaty Establishing the European Coal and Steel Community, Apr. 18, 1951, 261 U.N.T.S. 140; Treaty Establishing the European Economic Community, Mar. 25, 1957, 298 U.N.T.S. 11. Iceland did experience some modest opening to trade in the 1960s, when a coalition government of the Independence Party and the social democratic People's Party began to liberalize trade. Ásgeirsson, supra note 168, at 333-352.

${ }^{187}$ Boyes, supra note 4, at 79. See also Ásgeirsson, supra note 168, at 185-187.

${ }^{188}$ See Convention Establishing the European Free Trade Association, Jan. 4, 1960, 370 U.N.T.S. 5; Accession of Iceland to the European Free Trade Association, Dec. 4, 1969, 956 U.N.T.S. 468. The EFTA was a group of nonEEC European nations which sought to participate in the larger market the EEC was creating. 
In many respects, Iceland followed a path similar to that in other Western European nations, where restrictions on trade and capital movement declined over the 1970s, though Iceland tended to lag behind. Like many western economies, ${ }^{189}$ Iceland experienced significant inflation in the 1970s, although inflation in Iceland was worse and continued to grow into the 1980 s, reaching more than $100 \%$ in early $1983 .{ }^{190}$ This had a significant effect on the financial sector. The market for securities was non-existent and when real interest rates dropped as inflation rose, depositors of the banks tried to escape to commodities or real-estate. Those who had the possibility of borrowing either from the banks or the pension funds, so as to invest in housing, were heavily subsidized. ${ }^{191}$ The combination of inflation and state control of lending made loans a great deal for Icelanders, if they could get them.

For most of the inflation period, interest rates were far below the rate of inflation, so that interest on loans was in fact negative. People who borrowed money did not even have to pay the whole principal back. This could be beneficial for young people in need of an apartment, ... It was also favourable for various kinds of private enterprise and has no doubt contributed to much unprofitable investment. It has normally paid off in Iceland to do rather than to leave undone, which is the basic cause of the high demand for labour that has kept unemployment at bay. ${ }^{192}$

Of course, loans at negative real interest rates were bad for lenders. The result was that by 1978 the Icelandic banking sector had been "sliced in half." and encourage savings the government introduced indexation of financial obligations in 1979, which still remains common in Iceland financial transactions. ${ }^{194}$ However, until 1990 Icelandic economic policy was primarily aimed at keeping peace in the labor market and employment high. The results was a cycle of sectoral collective bargaining agreements providing for large wage increases followed by devaluations of the krona, which contributed to high inflation and left real wages subject to wild fluctuations. ${ }^{195}$

Not surprisingly, the combination of years of overexploitation of fishing resources, inflation, and economic instability meant that the Icelandic economy fell into stagnation in the late 1980s and early 1990s. The average economic growth per capita between 1988 and 1995 was $-0.7 \%$ and GDP fell by $5.6 \%$ during the period. ${ }^{196}$ Moreover, the regular bouts of inflation

\footnotetext{
${ }^{189}$ See Andrew Sentence, Global Inflation: How Big a Threat?, 48 BANK OF ENG. Q. BULL. 339 (2008) (discussing the current inflationary threat in terms of inflation in the 1970s and proposing ways to avoid the mistakes of the 1970s inflationary period); Peter M. Oppenheimer, Inflation: A Constraint on Foreign Policy?, 3 BRIT. J. OF INT'L STUD. 191 (1977) (analyzing 1970s inflation in the Western world in terms of its affect on foreign policy); Russell Napier, Why a Little Knowledge of Inflation Can Be Dangerous, FIN. TIMES, Jun. 9, 2009, at 22 (observing that in the coming years investors will face inflationary challenges unseen in the West since the 1970s).

${ }^{190}$ SIC's report, supra note 174 , chapter 4.3.3, at 82 .

${ }^{191}$ Eggertsson \& Herbertsson, supra note 149, at 11-13.

${ }^{192}$ Karlsson, supra note 6, at 351.

${ }^{193}$ Eggertsson \& Herbertsson, supra note 149, at 13.

${ }^{194}$ Eggertsson \& Herbertsson, supra note 149, at 15-16 ("In Iceland indexation proved highly successful in gradually restoring the stock of financial savings." ).

${ }^{195}$ SIC's report, supra note 174 , chapter 4.3.3., at 82 .

${ }^{196}$ SIC's report, supra note 174 , chapter 4.3.3., at 78.
} 
meant that the Icelandic currency had lost most of its value between 1938 and 1990, leading Iceland to introduce a new currency in 1981, replacing 100 old krona with 1 new krona (ISK). ${ }^{197}$ The value of the currency fell from 4.77 krona to the U.S. dollar and 22.15 to the British pound to 5,547 in "old" krona (or 55.47 in "new" krona) to the dollar and 10,639 (106.39) to the pound in 1990. ${ }^{198}$ As Financial Times reporter Roger Boyes summarized, in 1991 "[i]nflation was high; state coffers almost empty." 199 Thus by the early 1990s, Iceland was ready to try new economic policies.

\section{B. The Reform}

In 1991 Iceland had an economy built largely on fishing, together with some use of geothermal and hydroelectric power (supplying the energy-heavy aluminum export sector) and transfer payments from NATO's use of the Keflavik base. ${ }^{200}$ A new government took office in 1991 and embraced the global trend toward deregulation and decontrol in economic affairs. It launched a program of radical reforms of the country's troubled economy, a program which continued until the financial crisis. ${ }^{201}$ In particular, the government embarked on a series of

\footnotetext{
${ }^{197}$ Karlsson, supra note 6, at 351.

${ }^{198}$ Karlsson, supra note 6 , at 350.

${ }^{199}$ Boyes, supra note 4, at 33.
}

${ }^{200}$ Boyes, supra note 4, at 82; Thorvaldsson, supra note 43, at 17 (Icelandic economy in mid-1990s was "'a one trick pony... far too dependent on fishing, which accounted for close to 70 percent of exports.’)

${ }^{201}$ This was a coalition government led by the Independence Party’s (Sjálfstæðisflokkur) David Oddsson and the Public Party’s (Alpýðuflokkur) Jon B. Hannibalsson. Iceland's political system forces parties into coalition governments; all governments since cabinet government was introduced in 1917 have been coalitions. Karlsson, supra note 6, at 306. The modern Independence Party dates to 1929 and was generally seen as "the political home of the average nationalistic and even 'non-political' Icelander. Its name was said to refer to the independence of both the nation and the individual." Karlsson, supra, at 304. The Public Party later merged with the Public's Alliance (Alpýðubandalagið) to become the Social Alliance (Samfylkingin). The Public Party had traditionally ties with the labor unions and had supported nationalization of property and industries. However in the early 1990s free-trade tendencies grew stronger within the party. The coalition led commentators to compare this government to the coalition of the same parties in the 1960s that had brought about free-market oriented reform and supported the EFTA membership of Iceland.

On the reforms, see Dr. Eamonn Butler, What Brown Should Learn From the New Viking Raders, SuNDAY Bus. (LONDON), Sep. 4, 2005, at 1 ("[T]hanks to market liberalisation, tax cuts, privatisation and deregulation in the 1990s, Iceland is booming."); Tom Millward, The Hottest Economy in Scandinavia, CoRP. LOCATION, 1st Quarter 2000, at 38 (showing how deregulation and privitization during the the 1990s had brought to Iceland, in 2000, “a share of industries on the cutting edge of technology"); SIC's report, supra note 174, chapter 4.3., at 78. Though the coalition government broke up after the 1995 parliamentary election Iceland stayed on the course of market oriented reform. By then, the Progressive Party (Framsóknarflokkur) had adopted more market-friendly policies and led by a former minister of fisheries, Halldór Ásgrímsson, worked with the Independence party in government from 19952003.

On the connection to global trends, see Hannes H. Gissurarson, Miracle on Iceland, WALL STREET J. (Jan. 24, 2004) available at http://courses.wcupa.edu/rbove/eco343/040compecon/Scand/Iceland/040129prosper.htm ("after a radical and comprehensive course of liberalization that mirrors similar reforms in Thatcher's Britain, New Zealand and Chile, Iceland has emerged as one of the world's most prosperous countries"); Jonsson, supra note 24, at 37 on the focus turning to "Thatcherite, free market reforms in Britain"; Boyes, supra note 4, at ix (Iceland was "an earnest and enthusiastic copy of the changes introduced by Reagan in the United States and Thatcher in Britain"); id at 29-32 ("roots of Iceland's crisis" in Reaganism and Thatcherism and citing 1984 visit by Milton Friedman to Iceland as a significant event) and See Patricia A. McCoy, Andrey D. Pavlov \& Susan M. Wachter, 
reforms which transformed the financial sector, through consolidation and privatization; opened the country to global financial markets; and enabled the emergence of Icelandic markets in securities and currencies. Successive post-1991 Icelandic governments reduced public debt, introduced wide-ranging tax cuts, reformed pension funds, and transformed the fisheries industry through a de facto property-rights based management system. As a result, in a relatively short time, "Iceland went from being probably the least market-oriented of the Nordic countries, to the most." 202

This economic opening took place in a broader context of institutional change resulting from Iceland's signing the Agreement on the European Economic Area (EEA) on May 2 1992, effectively entering the single European market on January $1,1994 .{ }^{203}$ Joining the EEA obliged Iceland to adopt virtually the entire institutional and regulatory framework of the EU's Single Market, including its common rules and regulations for financial markets. ${ }^{204}$ The broad commitment to liberalization influenced the manner of implementation of EU regulations, as the Icelanders generally enacted the minimum requirements instead of opting for stricter regulatory frameworks within the the EEA Agrement. ${ }^{205}$

Finally, in addition to its financial reforms, the government launched a fiscally stimulative effort to build up the country's hydroelectric capacity as part of a campaign to lure aluminum

Systemic Risk Through Securitization: The Result of Deregulation and Regulatory Failure, 41 ConN. L. REV. 1327, 1333 (2009) (discussing two landmark pieces of legislation in the early 1980s which deregulated residential mortgage credit in the United States); Tamim A. Bayoumi, Financial Deregulation and Consumption in the United Kingdom, 75 REV. OF ECON. \& STAT. 536 (1993) (analyzing the correlation between the United Kingdom's financial deregulation in the preceding decade and a half and household consumption).

${ }^{202}$ Thorvaldsson, supra note 43, at 20. See also Boyes, supra note 4, at 37 (quoting 2001 speech by then-Finance Minister Geir Haarde summarizing a decade of government policy that reforms focused on four objectives: (1) privatization, (2) increasing efficiency, (3) broadening share ownership, and (4) reducing public debt.).

${ }^{203}$ On the EEA Agreement see, the European Free Trade Association's (EFTA) official website available at http://efta.int/eea/eea-agreement.aspx. ("The Agreement on the European Economic Area, which entered into force on 1 January 1994, brings together the 27 EU Member States and the three EEA EFTA States* — Iceland, Liechtenstein and Norway - in a single market, referred to as the "Internal Market". The EEA Agreement also states that when a country becomes a member of the European Union, it shall also apply to become party to the EEA Agreement (Article 128), thus leading to an enlargement of the EEA.

The EEA Agreement provides for the inclusion of EU legislation covering the four freedoms - the free movement of goods, services, persons and capital - throughout the 30 EEA States. In addition, the Agreement covers cooperation in other important areas such as research and development, education, social policy, the environment, consumer protection, tourism and culture, collectively known as "flanking and horizontal" policies. The Agreement guarantees equal rights and obligations within the Internal Market for citizens and economic operators in the EEA." See also SIC's report, supra note 174, chapter 4.3.4, at 85-86; Boyes, supra note 4, at 112113 ("Joining the European Economic Area in 1994 gave Iceland access to European markets, and it in turn broadly adopted European trading norms.")

${ }^{204}$ SIC's report, supra note 174, chapter 15.2. at 10-11. This excludes, of course, those rules and regulations relating to the euro, which is not a part of the Single Market but instead constitutes a special set of rules within the framework of the European Monetary Union, to which 16 of 27 EU-countries belong.

${ }^{205}$ SIC's report, supra note 174, chapter 15.4. at 22-23. The Committee concludes that according to parliamentary documents, debates in the Althingi and comments from interest groups that this was a policy decision by the government, since regulating further than the minimum of the EEA acts required would have a negative effect on the Icelandic financial sector's international competitiveness, SIC's report, supra, chapter 15.4., at 22-23. 
processors to the island. ${ }^{206}$ Thus, just as Iceland was opening its economy and adapting its regulatory structure to the EU norms, the government initiated a long-term program of fiscal stimulus. The result of these policies was a significant increase in economic freedom in Iceland, ${ }^{207}$ rapid economic growth and rising standards of living. ${ }^{208}$ Six sets of policies are important both for their contribution to the boom and their role in the later crisis.

First, the introduction of the individual transferable quota (ITQ) system in fisheries in 1991 transformed the country's main export sector trom an inefficient industry plagued by overfishing and overcapitalization into one that was competitive in global markets, profitable, and a source of innovation, technological knowledge and new wealth. ${ }^{209}$ Icelandic fishing firms began to sell into world markets in a sophisticated way, using financial instruments to hedge currency risks, providing high margin products, and improving both its economic sustainability and the sustainability of fish stocks. ${ }^{210}$ Iceland's ITQ system quickly became a paradigmatic example of how a system of legal title to property, even if imperfect, can bring dead capital to life and create an engine of progress. ${ }^{211}$ Not only did the implementation of the ITQ system create demand for sophisticated financial services and products within the country, it also created considerable wealth and, as fishermen sold their quotas as the industry consolidated, produced investors with money to invest. ${ }^{212}$

Second, the Icelandic government repeatedly cut taxes between 1995 and 2003. The corporate income tax rate was cut from $50 \%$ to $18 \%$, a flat personal income tax of less than $36 \%$ replaced a system of graduated rates with a top marginal rate of $-47 \%$; a flat $10 \%$ capital gains tax was introduced in 1997, replacing a system where capital gains (excluding interest payments) were categorized as general income and taxed as such, and property taxes were abolished. ${ }^{213}$ For comparison, consider Ireland's tax cuts which earned that country praise as a "Celtic Tiger:" The

${ }^{206}$ SIC's report, supra note 174, chapter 4.3.1., at 80. Boyes, supra note 4 , at 83 . Aluminum smelting began in the mid-1960s and, after a major push by the Icelandic government, by 2003 Iceland was the largest producer per capita of aluminum in the world. Id.

${ }^{207}$ GWARTNEY AND LAWSON, supra note 1, (showing that Iceland's economic freedom score placed them $26^{\text {th }}$ in the world in $1990,17^{\text {th }}$ in $1995,12^{\text {th }}$ in 2000 , and $9^{\text {th }}$ in 2004).

${ }^{208}$ In 2005 in the beginning of the rise of the Icelandic economy, the country ranked highest in UN's Human Development Index which according to its authors a standard measure of "life expectancy, literacy, education and standards of living for countries worldwide," ranking number 6 in 1995. This indicates that increased economic freedom did not reduce the living standards of the poorest people in Iceland or the well being of the general public. See, United Nations Develepment Programme, available at: http://hdr.undp.org/en/humandev/.

${ }^{209}$ Boyes, supra note 4, at 7 (noting that "Icelanders are indeed financially sophisticated").

${ }^{210}$ Boyes, supra note 4, at 82 (noting that in 1990s "fish finance, the funding of expansion by borrowing against future catches, was gradually supplanting the gritty business of netting the cod and

${ }^{211}$ See Ragnar Árnason, Iceland's ITQ system creates new wealth, 1 ELECTRONIC JOURNAL OF SUSTAINABLE DEVELOPMENT (2008) available at http://www.ejsd.org/docs/ICELANDS_ITQ_SYSTEM_CREATES_NEW_WEALTH.pdf.

212 Thorvaldsson, supra note 43, at 117-18.

${ }^{213}$ See Cutting Taxes to Increase Prosperity, RSE February 2007, especially Daniel Mitchell 121-138 and Hannes Gissurarson 139-154. In 2007 capital gains tax revenue was close to 30 billion ISK while being below 1 billion in the first year after its introduction. Source: Minstry of Finance's Online Magazine, May 15, 2008. See also Thorvaldsson, supra note 43, at 99 (attributing difference between Icelandic and Danish work ethics to Denmark's ,punishing tax regime“.) 
Irish corporate tax rate fell from $40 \%$ in 1996 to $24 \%$ by 2000 ; the standard income tax rate went from $35 \%$ in 1988 to $22 \%$ in 2001 ; the top marginal rate went from $58 \%$ in 1988 to $44 \%$ in $2001 .{ }^{214}$ Iceland's tax rate changes dramatically changed the business climate in Iceland, making it an attractive place to realize capital gains and earn business profits. Moreover, as the boom developed, "every sector" of the economy was affected: "florists, taxi drivers, advertising agencies, restaurants and hotels". 215

Third, the government substantially reduced central government net debt, enhancing the credit worthiness of the Icelandic government, which received Aaa ratings from Moody's for seven years between $2002-2008 .^{216}$ From $25.6 \%$ of GDP in 1998, the government net debt fell as low as $3.9 \%$ of GDP in $2006 .^{217}$ The debt reduction was mainly the result of an increase in government revenue during the years of growth, caused by the combination of economic growth (as high as 7.7\% in 2004 and $7.5 \%$ in 2005) and sales of public enterprises. ${ }^{218}$ From an average fiscal deficit of approximately $2.5 \%$ of GDP between 1985 and $1996,{ }^{219}$ Iceland went to a budget surplus between 1997-2000 (1\% of GDP on average), a deficit between 2001-2003 (1\% of GDP on average), surplus in 2004 (1\% of GDP) and then a staggering surplus in 2005-2007 (an average of $4.5 \%$ of GDP). ${ }^{220}$ This did not mean that the government was spending less: government spending rose steadily during these years and increasing by more than $40 \%$ between 2003-2008. ${ }^{221}$ The reduction of government net debt proved to be the key to the Icelandic capital market's access to credit on favorable terms, as we discuss below.

Fourth, Iceland reformed its pension system in a manner that boosted the financial sector. Iceland initiated a compulsory individual savings scheme in 1970; by the 1990s these funds

\footnotetext{
214 See Benjamin Powell, Economic Freedom and Growth: The Case of the Celtic Tiger, 22 CATO J. 431, 436-437 (2003) (Powell provides detailed information on Ireland's tax rates during the 1990s and early 2000s); Moore MacDowell, Capital Gains Taxation in Ireland, in InTERNATIONAL EVIDENCE ON THE EFFECTS OF HAVING No CAPITAL GAINS TAXES 141, 149-150 (Herbert G. Grubel ed., 2001), available at http://www.fraserinstitute.org/Commerce.Web/product files/IntlEvidenceNoCapitalGainsTaxSec3C.pdf

(MacDowell describes how the Irish capital gains tax was overhauled in 1994 to a single 40\% rate, with a couple of exceptions where the rate was even lower. Before this 1994 overhaul there were four holding period rates for capital gains taxation purposes: $60 \%$ for less than a year, $50 \%$ for less than 3 years, $35 \%$ for less than 6 years, and $30 \%$ for more than 6 years. In 1997 the rate was reduced to $20 \%$, with the stipulation that this rate was to be temporary for development land with a residential zoning.); See also Frederick Kempe, Jockeying Over Investment Heats Up in Europe --- Germany's Schroeder Warns Against Tax Competition, Calls for Agreement on Rates, WALL ST. J., Apr. 30, 2004, at A12 (reporting on Germany's warnings to incoming EU members not to copy Ireland's low corporate tax rates (13\% in 2004) which Germany terms "tax dumping”).

215 Thorvaldsson, supra note 43, at 146-47.

${ }^{216}$ SIC's report, supra note 174 , chapter 4.2.4., at 71.

${ }^{217}$ Ministry of Finance, The National Economy - Fall Report 2009 (Icelandic: Pjóðarbúskapurinn - haustskýrsla 2009), Table 13.

${ }^{218}$ Ministry of Finance, supra note 217, available in the dataset at http://www.fjarmalaraduneyti.is/Utgefidefni/thjodarbuskapur/nr/12544.

${ }^{219}$ SIC's report, supra note 174, chapter 4.4.1., at 99.

${ }^{220}$ SIC's report, supra note 174, chapter 4.4.1. at 99.

${ }^{221}$ Hauksson, supra note 40.
} 
represented significant future claims. ${ }^{222}$ Beginning in 1997 for private pension funds and 1999 for public pension funds, all pension funds were required to be fully funded. ${ }^{223}$ This system of accumulative pension rights in fully funded pension funds, financed through a compulsary savings scheme, compared favorably with the pay-as-you-go pension systems in most of Europe. $^{224}$ Total pension fund assets amounted to $100 \%$ of GDP in $2003 .{ }^{225}$ By comparison, the OECD average was only $60 \%$ of GDP, a level barely exceeded by the United States and the United Kingdom. ${ }^{226}$ "Per capita, the pension funds of Iceland were bigger than the famous Norwegian oil fund."227 When Iceland liberalized its economy, the Icelandic pension funds used this wealth partly to invest abroad, but they also provided considerable liquidity for the Icelandic stock market and financial sector more broadly and became key institutional investors in the Icelandic economy. ${ }^{228}$

Fifth, the Icelandic financial sector was completely transformed by changes in regulatory structures and privatization of state-owned financial companies. ${ }^{229}$ Interest rates were decontrolled in 1984-1986. ${ }^{230}$ The Icelandic Stock Exchange was founded in 1985 and an organised market for securities and stock gradually emerged and matured in the $1990 \mathrm{~s}^{231}$ Exchange rates were freed in May 1992 when an interbank market in currency trading was established, although the market was still under Central Bank supervision. ${ }^{232}$ In March 2001 the Central Bank opted for a inflation-targeting-based monetary policy establishing an active currency market where the exchange rate was decided on the grounds of supply and demand. ${ }^{233}$ Private entities gradually began creating new financial instruments, with the first foreign exchange options and swaps on the krona appearing in $1996 .{ }^{234}$ Further, as previously mentioned, the EEA agreement decontrolled capital flows between Iceland and Europe beginning in the mid-nineties.

\footnotetext{
222 See Már Guömundsson, The Icelandic Pension System and the Financial Crisis, Speech, May 2, 2010, available at http://www.bis.org/review/r100510b.pdf at 2-3; Már Guömundsson, The Icelandic Pension System, National Association of Pension Funds (January 2001) at 2-9 (describing pension fund system).

${ }^{223}$ Pension Act no. 129/1997, sections IV-VII, especially Art 39.

224 OECD FINANCIAL AFFAIRS DIVISION supra note 7.

${ }^{225}$ OECD FINANCIAL AFFAIRS DIVISION supra note 7.

${ }^{226}$ OECD FINANCIAL AFFAIRS DIVISION supra note 7.

227 Thorvaldsson, supra note 43, at 117.

${ }^{228}$ Thorvaldsson, supra note 43, at 29-30, 116-117 (describing pension funds movement into international investing in 1990 s, role in 2000 s in providing liquidity).

${ }^{229}$ Jonsson, supra note 24, at 40-42; Ministry of Commerce, Iceland, Structural Changes in the Financial Markets in Iceland: Information Memorandum, August 1997, available at http://www.idnadarraduneyti.is/media/Acrobat/STRUCT.PDF; Thorvaldsson, supra note 43, at 52 (Privatization of non-financial companies began in the early 1990s, "initially focused on smaller, state-owned companies." ).

${ }^{230}$ SIC's report, supra note 174 , chapter 4.3.3., at 83 ..

${ }^{231}$ Gylfi Magnússon, A Market Emerges: History of the Icelandic Stock Market. (Markaður verður til: Saga íslenska hlutabréfamarkaðarins.) Institute of Economic Studies, December 2007, at 31 ..

${ }^{232}$ Central Bank of Iceland, Peningamál, 2001, No. 3, at 54.

${ }^{233}$ Central Bank of Iceland, Peningamál, 2001, No. 3, at 55.

234 Thorvaldsson, supra note 43, at 21-22 (describing creation of these products).
} 
The next step was reform and privatization of the state-controlled institutions that made up the financial sector. The scope of that reform can be seen by comparing that pre-reform sector in 1990 with the post-reform sector in 2003. Before 1990 the Icelandic banking sector consisted of four privately owned banks focused on particular industries, three state-owned commercial banks, thirty-two small savings banks spread around the country, and one investment bank, Kaupthing. ${ }^{235}$ In addition, there were several public industry-specific credit funds extending loans to companies in certain sectors of the economy, primarily in distressed areas. ${ }^{236}$ Prior to 2003 the financial sector in Iceland, with Kaupthing and FBA (the Investment Bank of the Industries, Icelandic: Fjárfestingarbanki Atvinnulífsins.) investment banks as notable exceptions, had predominantly been built up of traditional commercial banks dealing primarily with their local customers. ${ }^{237}$ Looking at the three biggest banks, there was not much difference in lending activity between the private Islandsbanki and the public Bunadarbanki and Landsbanki. ${ }^{238}{ }^{2}$ When the government finally sold controlling stakes in Landsbanki and Bunadarbanki, and the latter had merged with the investment bank Kaupthing, the stage was finally set for the expansion of the Icelandic financial sector. ${ }^{239}$

By 2003, Iceland's financial sector was structured completely differently from how it had been a mere ten years earlier. From a tightly controlled and highly-political universe of statecontrolled and owned institutions lending primarily to specific industries or for specific purposes

\footnotetext{
${ }^{235}$ Thorvaldsson, supra note 43 , at 6,52 .

${ }^{236}$ Those were for example the Icelandic Fisheries fund (Fiskveiðasjóður Íslands), the Industry Loans Fund (Iðnlánasjóður), the Export Loans Fund (Útflutningslánasjóður) and the Industry Development Fund (Iðnpróunarsjóður), all four merged into the FBA (the Investment Bank of the Industries, Icelandic: Fjárfestingarbanki Atvinnulífsins.) by Act no. 60/1997, see SIC's report, supra note 174, chapter 5.2. at 209 (describing the formation and privatization of FBA). .

${ }^{237}$ SIC's report, supra note 174, chapter 21.2.1.1. at 177. Jonsson, supra note 24, at 40-43.

${ }^{238}$ SIC's report, supra note 174, chapter 21.2.1.1. at 177-178.- Jonsson, supra note 24, at 98 ("Islandsbanki traveled the rockiest road....it was transformed from the most risk-averse bank into the biggest risk taker.")

${ }^{239}$ The four industry-focused banks, the Fisheries bank (Útvegsbankinn), Industry bank (Iðnaðarbankinn), Public's bank (Albýðubankinn) and Commerce bank (Verslunarbankinn) were merged into the privately held Islandsbanki (later Glitnir).. The public investment funds, see note 237, were merged into the FBA, and then privatized in 1998. : See SIC's report, supra note 174, chapter 5.2. at 209 and 232 (describing the formation and privatization of FBA).; Thorvaldsson, supra note 43, at 32 (describing formation of FBA). The FBA merged with Islandsbanki in 2000, Jonsson, supra note 24, at 98-99. Two of the state-owned commercial banks, Bunadarbanki and Landsbanki, were privatized in 2003. -SIC's report, supra note 174, chapter 6 at 227-306 (providing a detailed description of the privatizion process). Baldursson and Portes summarize a few very important factors in Iceland's rise in their report on the Internationalisation of the Icelandic financial system:
}

\begin{abstract}
Most importantly, the Icelandic banks were privatized at the same time that international interest rates were low and liquidity was ample. The banks could therefore escape the limitations set by the small size of the Icelandic economy and seek new markets. This they did with alacrity, acquiring financial firms in other countries and establishing branches. Their growth has been spectacular: total assets of the banking sector have grown from $96 \%$ of GDP at the end of 2000 to eight times GDP at the end of 2006. The majority of the banks' revenues originate outside Iceland, mainly in other northern European countries.
\end{abstract}

Friðrik Már Baldursson and Richard Portes, The Internationalization of Iceland's Financial Sector, Iceland Chamber of Commerce Report, November 2007 See also: Ragnar Arnason, Iceland ITQ system creates new wealth, The Electronic Journal of Sustainable Development (2008) I (2), International Policy Network and the University of Buckingham. 
and almost exclusively within Iceland, Icelandic financial institutions had become private entities operating in a wide range of activities both domestically and internationally. From the beginning of the privatization process of the Landsbanki and Bunadarbanki in 1999, the banking sector underwent important structural changes and the banks had started operating within the framework of common European rules, adopted through the channels specified in the EEA agreement. Freedom of capital flows were firmly established, Icelanders became an integrated part of the Single Market, and both Icelanders and Icelandic firms could freely move about within the Single Market to seek new business opportunities. As Icelandic firms expanded into Europe, investments in Icelandic companies became investments in Europe broadly, rather than just in Iceland. ${ }^{240}$

The liberalization of the financial sector was not without controversy. The idea of liberalization and privatization within the banking sector in Iceland had widespread popular support, in part because many saw the banks as too conservative and old-fashioned for a modern economy and in part because they were seen as too close to political power and indulged favoritism. ${ }^{241}$ The process of privatization, however, provoked some controversy as the parties in government at the time of privatization, the Progressive Party (Framsóknarflokkur) and the Independence Party (Sjálfstæðisflokkur), had historically closer ties to the business sector than the parties on the left, and some saw politics at play in the sale of the banks. ${ }^{242}$ Instead of selling to the highest bidders, it was claimed, controlling stakes in the two banks were sold to party favorites. ${ }^{243}$ The truth of the matter has never been completely established, but it is widely

\footnotetext{
${ }^{240}$ Thorvaldsson, supra note 43, at 148 ("You weren't really investing in Icleand if you bought shares on the Icelandic Stock Exchange. More than 70 percent of the income of listed companies came from abroad.")

241 "There was no way to borrow to build a fence or buy a car, or to obtain dollars to go abroad without kissing the rings of political functionaries." Thorvaldur Gylfason, Professor of Economics University of Iceland, Iceland after the fall, Article for the Milken Institute Review, revised 20 November 2009, See: https://notendur.hi.is/gylfason/Milken\%20Institute\%20Review\%20article\%20on\%20Iceland.pdf

242 Thorvaldur Gylfason, Iceland's blend of old and new, July 10, 2008, Vox.Eu.org, http://www.voxeu.org/index.php?q=node/1387: "The privatization was long overdue, but its implementation was flawed; for example, a couple of major players in the ruling coalition that privatized the banks either became rich very rich - or kept their seats on the banks' boards after the privatization, or both. The editor of Morgunblaðið, a daily newspaper with close ties to the Independence Party, the largest political party, described the privatization process in a celebratory essay on the prime minister in 2004, presumably published with the subject's prior approval. The editor wrote that, given that the then second-largest political party had secured its claim to the second largest state bank, the prime minister, now self-appointed Central Bank governor, "considered it necessary that Landsbanki would land in the hands of persons within at least calling distance of the Independence Party" (my translation, TG). The main aim of the privatization ought to have been to sever completely the old ties between the political parties and the banks, as I advised the government in 1993 in a published report, but that was not to be." Thorvaldsson, supra note 43, at 102 ("The process and the decision making, however, was very political. Essentiallly it had been decided that groups close to the two political parties in power would be the favoured biddres, one bank for each group.") Thorvaldsson also argues that the privatization was less successful than it might have been because the government overestimated international interest in the banks and so attached too many conditions to the privatizations. Thorvaldsson, supra note 43, at 102.

243 Boyes, supra note 4, at 41-44 (quoting Icelandic economist Gylfi Magnusson as terming bank privatization "the Original Sin, the beginning of Iceland's fall from grace."); id. at 71 (analogizing the Independence Party to "the nomenklatura system practiced by the East European Communists during the Cold War. All power derived from the party, which handed out rewards and took them away again.") SIC'report, supra note 174, chapter 6 at 227-306 (providing a detailed description of the privatizion process).
} 
believed in Iceland that the selection of buyers, who became key players in the financial sector in the years that followed, contributed to a large extent to the rise and fall of the banks. ${ }^{244}$

Sixth, as noted above, the Central Bank in March 2001 opted for a inflation targeting based monetary policy establishing an active currency market where the exchange rate was decided on the grounds of supply and demand. ${ }^{245}$ A 2001 statute formally established the central bank's independence, though political intervention in its affairs had already declined during the 1990s. ${ }^{246}$ A manual devaluation of the currency to boost the export sector and make up for budget deficits, a common practice in Iceland most of the 20th century, even after the introduction of the new ISK in the 1980s was obviously not to play any part of the 21 st.

\section{The Boom}

During the latter half of the 1990s the economy grew while an open financial market emerged. Investment by both companies and households increased through the Iceland Stock Exchange. ${ }^{247}$ The bursting of the global tech bubble at the turn of the millennium slowed the boom but the banking sector was not seriously hurt. ${ }^{248}$ Freed from state control, backed by a strong ISK, under an expansionary monetary-policy regime, and with the opportunities of the Single Market before them, ${ }^{249}$ the Icelandic banks quickly began acquiring European banks to expand outside the limited local market. ${ }^{250}$ Between March 2004 and June 2008, the total

\footnotetext{
${ }^{244}$ See note 242. See also Robert Wade, Iceland pays price for financial excess, Financial Times, July 12008. http://www.ft.com/intl/cms/s/0/061070b8-4781-11dd-93ca-000077b07658.html\#axzz1 mdbVWkeg: "The banks were privatised around 2000 in a hasty and politically driven process. Ownership went to people with close connections to the parties in the conservative coalition government, which had scant experience in modern banking. The central bank and the finance ministry were staffed at the top by people who preferred as light a regulatory touch as possible."

${ }^{245}$ Central Bank of Iceland, Peningamál, 2001, No. 3, at 55. SIC's report, supra note 174, chapter 4.3.3., at 88.

${ }^{246}$ Act on the Central Bank of Iceland no 36/2001, Art 1. Par. 1. In a speech proposing the Act in the Althingi, Prime Minister David Oddsson emphasized the importance of independence and professionalism in the Central Bank's monetary policy decision making: http://www.althingi.is/altext/126/04/r06103212.sgml.

${ }^{247}$ Jonsson, supra note 24, at 86-91 ("The ICEX from dawn to decadence")

${ }^{248}$ Jonsson, supra note 24, at 86-91 ("The ICEX from dawn to decadence")

${ }^{249}$ Ingimundur Fridriksson, Governor of the Central Bank of Iceland, 2002-2003, 2006-2009, in a talk prepared for a seminar in the Central Bank of Finland, February 6, 2009, at page 1 ("The European regulatory framework gave the Icelandic banks the same operational flexibility all over the EEA as they enjoyed in Iceland. They had the same rights and responsibilities as banks in all of the other EEA states. The Icelandic Financial Supervisory Authority based its operations on European law, regulations, and procedures, and was given good marks by rating agencies and the International Monetary Fund.").

${ }^{250}$ In 2000, FBA investment bank acquired the UK-based private bank Raphael \& Sons. Central Bank of Iceland, Annual report 2000, Chapter 2, Financial System, p. 25. http://www.sedlabanki.is/uploads/files/ar00 2.pdf, In the beginning of 1998, FBA was actually the only Icelandic bank with international credit rating (A3, at Moody's) and in February 1999 was the first of the banks to sign an agreement on issueing international bands in the London Stock Exchange (European Medium Term Notes), SIC's report, supra note 174, chapter 7.2., p. 10. On July 18, 2000 Landsbanki bought a 70\% stake in the UK-based Heritable Bank. Central Bank of Iceland, Annual report 2000, Chapter 2, Financial System, p. 25. http://www.sedlabanki.is/uploads/files/ar00 2.pdf, see also SIC's report, supra note 174, Volume 1, p. 199. Kaupthing began operating a subsidiary in Luxembourg in 1998. By 2002, before the privatization of Landsbanki and Bunadarbanki was complete, and before its merger with Bunadarbanki (which was finalized in May 2003) Kaupthing was operating in Luxembourg, Copenhagen, Stockholm, Helsinki, London and New York, although on a relatively small scale. See also: Central Bank of Iceland, Annual reports 2000, 2001 and
} 
liabilities of the banking sector grew from $160 \%$ to staggering $920 \%$ of Iceland's GDP. ${ }^{251}$ Despite this expansion, the banks retained excellent credit ratings. For example all of them received top ratings for long term commitments as late as February $2007 .^{252}$ The importance of the country's three largest banks, Glitnir (the former Islandsbanki), Kaupthing, and Landsbanki in the new deregulated financial sector can hardly be overstated. By June 2008 the total assets of just those three banks amounted to approximately ten times GDP. ${ }^{253}$

There was not just structural change in the banking sector in Iceland in the 1990s and early 2000s, banking culture was transformed as well. Conservative, middle-aged men were replaced by young, vigorous, entrepreneurs, usually well educated. ${ }^{254}$ So bank policies were transformed, and new systems of remuneration created great incentives for further growth, expansion and risky behavior. ${ }^{255}$ Soon the lucrative remuneration systems attracted educated people and young people flocked to university faculties of business, economics and law during the economic boom. ${ }^{256}$

2002, Chapter 2, Financial System, http://sedlabanki.is/?PageID=235, and Central Bank of Iceland, Financial Stability Report, 2005, p. 27-29. http://www.sedlabanki.is/lisalib/getfile.aspx?itemid=2913. In late 2002 the Swedish financial surveillance authority, Finansinspektionen, accepted Kaupthing's acquisition of JP Nordiska bank in Stockholm. SIC's report, supra note 174, Volume 1, p. 199. On February 2004 Kaupthing bought $10 \%$ of the London based UK bank Singer \& Friedlander, then holding a total of 19,53\% of the total stock. Id. On June 14, 2004, Kaupthing doubled its balance sheet by acquiring the Danish investment bank FIH. Id. On January 20, 2005 Íslandsbanki hf. (later Glitnir) acquired the Norwegian bank BN bank, and consolidated Íslandsbanki's concern in Norway. Id.

${ }^{251}$ SIC's report, supra note 174, Volume 1, at 200. See also, IMF Country Report No. 08/362, Iceland: Request for Stand-By Arrangement-Staff Report; Staff Supplement; Press Release on the Executive Board Discussion; and Statement by the Executive Director for Iceland, p. 14, International Monetary Fund, November 2008, available at: http://www.imf.org/external/pubs/ft/scr/2008/cr08362.pdf. ("The Icelandic banking sector experienced a dramatic expansion in just a few years, funded by cheap foreign financing, which allowed it to boost its assets from 100 to almost 900 percent of GDP between 2004 and end-2007. This expansion made the Icelandic banking system one of the largest in the world in relation to GDP")

${ }^{252}$ SIC's report, supra note 174, Volume 2, at 13. The Royal Bank of Scotland „blasted“" Moody's for the ratings of the Icelandic banks in February 2007. See Bloomberg's John Glover February 26, 2007:

http://www.bloomberg.com/apps/news?pid=newsarchive\&sid=aFU1Ddtg2k8M\&refer=home. Moody's stock prices fell 6\% the same day, and the agency downgraded the Icelandic banks to Aa3 in April same year. SIC's report, supra note 174, Volume 2, p. 13.

${ }^{253}$ SIC's report, supra note 174, Volume 2, p. 88-92. Statistics Iceland: www.statice.is.

${ }^{254}$ Dr. Hulda Thorisdottir, Afsprengi aðstcðna og fjötruð skynsemi: Aðdragandi og orsakir efnahagshrunsins á Íslandi frá sjónarhóli kenninga og rannsókna í félagslegri sálfrææði, a special report published in Althingi Research Committee's Report, Volume 8, On pages 287-288 Dr. Thorisdottir lays out the sociological and psychological reasons for this transformation in the Icelandic banking sector, from a theoretical perspective. She notes that the typical employee in the coroporate finance departments and in securities and stock broking was a 25-40 year old male that in accordance with theory attracted like-minded characters. ("Birds of a feather flock together").

${ }^{255}$ SIC's report, supra note 174, Volume 3, chapter 10, at 25-98. The committee publishes wide range of documents and extensive information on the remuneration systems implemented in the three banks during the boom. The committee concludes that the dramatic rise in payments for bankers, in the form of salaries, bonuses, pension schemes and stock-options, contributed to the risky behavior and the strife for expansion of the Icelandic bankers.

256 Thorisdottir, supra note 254, at 288. She notes at 285 that between 1998 and 2008 the student increase in Icelandic universities in the faculties of business administration and marketing was $111 \%$ in bachelor programs and $327 \%$ in masters programs. Since the financial crisis it has become common for outside commentators to mock the 
This growth is not surprising, at least in retrospect. As we discussed earlier, monetary policy around the world was increasing liquidity, creating a large pool of money seeking returns and the Icelandic banks took advantage of these conditions to raise money through bonds, $€ 14$ billion in 2005 alone. ${ }^{257}$ U.S. bond markets also found Icelandic banks' offerings attractive based the combination of the favorable ratings of and the high interest rates offered on ISK-denominated bonds, which made them a desirable ingredient in collateralized debt obligations. ${ }^{258}$ The Icelandic banks appeared to be excellent investments and business partners, as they had strong credit ratings. ${ }^{259}$ These ratings stemmed not just from the banks' balance sheets but also from the value of the government backing (given the government's strong financial position). ${ }^{260}$ As former Icelandic Central Bank governor Ingimundur Fridriksson noted: "Financial markets were hungry for bonds, including those issued by Iceland's banks, which were a welcome addition to many of the structured securities that became so popular. The banks were thoroughly scrutinized

Icelandic banks for venturing into international finance, suggesting that the banks were staffed by legions of former fishermen who had only recently traded their overalls and raincoats for business suits. Some examples:

- "What led a tiny fishing nation, population 300,000, to decide, around 2003, to re-invent itself as a global financial power?” Lewis, supra note 21.

- "Both debtors and creditors believed in an Iceland that could never exist, a society that could talk its way out of poverty into prosperity, not in a generation but in a decade. Was that a ridiculous dream? Yes, it was." Boyes, supra note 4, at 93.

- 'All [Kaupthing executives] (except [CEO] Sigurdur [Einarsson]) in our late twenties with just three years' work experience, we were now firmly established as the management team at Kaupthing .... There weren't many people with more experience of any relevance. Ten years earlier the stock market didn't even exist. The market had developed so rapidly that experience from more than a few years ago just wasn't that relevant." Thorvaldsson, supra note 43 , at 33.

The roots of the Icelandic financial crisis do not lie in the Icelandic banks' failure to hire enough university graduates, experienced M.B.A. graduates of prestigious universities in Europe or North America or the banks' lack of a long tradition of banking. If those would have been sufficient to prevent problems, Lehman Brothers' lengthy history and legions of top M.B.A. graduates would have prevented that firm's collapse in 2008. Moreover, as we noted earlier, the Icelandic fishing industry had developed into a financially sophisticated international business from the 1980s, used to operating across the globe, engaging in financial transactions to hedge risks, market high end products internationally, and model complex natural systems. There may have been some ex-"fishermen" working at the Icelandic banks, but they were not the financial naïfs portrayed in popular accounts.

${ }^{257}$ SIC's report, supra note 174 , Volume 1, at 31 . The committee notes that had to pay only 20 basis points above interbank reference rates on their 2005 bond issuance. And that the three banks issued in 2005 double the amount they had in 2004 ..

${ }^{258}$ SIC's report, supra note 174, Volume 1, at 31-32.

${ }^{259}$ Thorvaldsson, supra note 43, at 109-110 (discussing Kaupthing's bid for the Danish investment bank FIH and concluding that Kaupthing's desire to grow FIH had persuaded FIH to accept its bid); Ingimundur Fridriksson, Governor of the Central Bank of Iceland, 2002-2003, 2006-2009, in a talk prepared for a seminar in the Central Bank of Finland, February 6, 2009, at page 1. Thorvaldsson, supra note 43, at 146 (noting role of "strong single A credit ratings" of banks in raising money early 2000s). See also Thorvaldsson, supra, at 106 (stronger credit rating after merger with Bunadarbanki "completely changed how we funded the bank. ... Now, we suddenly had almost limitless ways of issuing debt abroad.”)

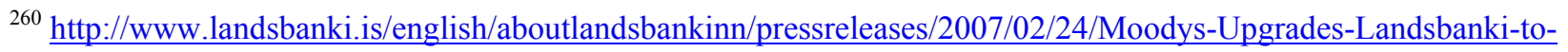
Aaa--Changes-BFSR-Outlook-to-Stable/? $\mathrm{p}=8$ They also reflected the Icelandic banks' growing size, as they expanded across Europe. For example, Kaupthing's rating was raised by Moody's from A2 to A1 after Kaupthing acquired FIH. Thorvaldsson, supra note 43, at 113. 
by international rating agencies and their favourable credit ratings greatly facilitated the banks' foray into the bond market.",261

The boom produced more than banking expansion; it also fueled a dramatic leveraged expansion of the private sector. Total bank credit to the Icelandic private sector grew annually by $34.2 \%$ between $1999-2006$ and from 64\% of the national GDP in 1998 to 350\% of GDP in $2007 .{ }^{262}$ From 2004 until the collapse, the average annual increase of credit to the market on behalf of the big three banks was $50 \% .{ }^{263}$ Because foreign capital was cheap and easy to access, Icelandic companies began looking for growth outside their small home market, working closely with the banks. As the access to capital increased the Icelandic banks gradually assumed a larger role as investment banks instead of the previous role as basic commercial banks. From 20032008 the increase of credit from the banks to the corporate sector was largely to holding companies that more often than not were investment vehicles for Icelandic investors expanding their private equity portfolio home and abroad. ${ }^{264}$ To a large extent, loans to the Icelandic holding companies from the banks were denominated in foreign currency even when the leveraged investment was in domestic equity in the ISK. ${ }^{265}$ Higher interest rates in ISKdenominated loans and consequently an increasingly strong ISK, made loans denominated in foreign currency at much lower rates an irresistible proposition.

The economic boom similarly affected Icelandic households. Household debt doubled between 2002 and 2007, from 750 billion ISK in 2002 to 1550 billion ISK in $2007 .{ }^{266}$ Although Icelanders by and large had their income in ISK many of them borrowed from the banks in foreign currency, in essence participating in speculative currency trading. Household debt in foreign currency at the banks was around $8 \%$ of the total in $2004,11 \%$ in 2006 but $29 \%$ at the end of September 2008. ${ }^{267}$ Most significant was household leveraged investment in housing. Gros notes: "[...] the boom in Iceland beats all records. Investment in dwellings is still close to $11 \%$ of GDP, which is almost twice the U.S. value and much higher than the Spanish value (which is the highest among the euro area countries)."268

\footnotetext{
${ }^{261}$ See for example, Moody`s Investor Services` Credit Opinion February 2007. http://news.icex.is/newsservice/MMIcexNSWeb.dll/newsattachment?attachmentnumber=17328

${ }^{262}$ SIC's report, supra note 174, Volume 2, at 88. The committee cited on corporate debt Hilbers, P.; I. Otker-Robe; C. Pazarbasioglu og G. Johnsen: "Assessing and Managing Rapid Credit Growth and the Role of Supervisory and Prudential Policies.“ IMF Working Paper nr. 05/151, Washington DC, International Monetary Fund, 2005.

${ }^{263}$ SIC's report, supra note 174 , Volume 1, at 31.

${ }^{264}$ SIC's report, supra note 174, Volume 2, at 93-96.

${ }^{265}$ SIC's report, supra note 174 , Volume 2, at 96-97. The committee states that more than half of all credit to the holding companies was denominated in foreign currency.

${ }^{266}$ SIC's report, supra note 174, Volume 1, at 183. Boyes, supra note 4, at 90 ("House prices went through the roof - and the Icelanders felt they had been touched with wealth. Using their houses as security, they started to buy new furniture, new cars, trailers, motorbikes, summer cottages. At the same time salaries were growing and the Icelandic krona seemed not just muscular, it was virtually on steroids.")

${ }^{267}$ SIC's report, supra note 174, Volume 2, at 99. After the collapse there has risen a legal dispute between creditors and debtors on the validity of the loans denominated in foreign currency. The Supreme Court ruled in 2010 that loans indexed in foreign currency but not in "real" foreign currency are in fact illegal.

${ }^{268}$ Daniel Gros, Iceland on the brink? Options for a Small, Financially Active Economy in the Current Financial Crisis Environment, CEPS Policy Brief No. 157, April 2008, Center for Policy Studies, at 6. On the value of housing investment in the United States, see National Association of Home Builders, Housing's Contribution to
} 
To regulate the financial sector, Iceland adopted regulations and institutions derived from two separate sources. From the UK, Iceland copied financial regulatory structure, dividing regulatory authority between the central bank and a new Financial Surveillance Authority (FSA), which was given the task of monitoring of financial institutions, including banks, savings institutions, insurance companies, and investment and pension funds. ${ }^{269}$ From the EU, Iceland copied its banking regulations. ${ }^{270}$ There was however little debate on whether the Icelandic banking sector needed to do more than was the norm in larger economies. There is no evidence of consideration being given to the possible threats from great inflow of borrowed foreign capital or from supersized balance sheets relative to national GDP. Similarly, there is little evidence of research by the Icelandic legislators at the time of privatization and the financial reform on how small, open economies (e.g. Luxembourg) have successfully or unsuccessfully built up international banking sectors. The only systematic analysis we are aware of was the November

Gross Domestic Product, available at http://www.nahb.org/generic.aspx?genericContentID $=66226$ (5\% for private residential investment). The government's role in the housing boom cannot be overlooked. Until 2004 Icelanders typically financed their homes by borrowing up to two thirds of the purchase price from the state owned Housing Fund ("HF"), which was the sole operator in mortgage lending. The remainder of the cost was borrowed from the banks and pension funds, with the borrower providing a guarantor (often relatives of individual borrowers) for the payment of this secondary loan. During the Parliamentary election campaign in 2003 the Centre Party (Framsóknarflokkur) promised to change the system so that the HF would lend $90 \%$ of the value of a real-estate to homeowners, and when elected pushed the idea through. Boyes, supra note 4, at 89 . The Central Bank and the Institute of Economic Studies at the University of Iceland had warned against the policy changes at the HF. Former Prime Minister Geir H. Haarde described this at a hearing before SIC that this policy shift was a "pure mistake", SIC's report, supra note 174, Volume 1, at 203-204. The committee furthermore notes that the HF competed fiercely on the market and contributed to the housing bubble. Structural changes were also made at the HF to facilitate access for foreign investors to HF bonds to secure better terms of financing and consequently interest rates on mortgages were lowered. SIC's report, supra note 174, Volume 1, at 120. Whether in direct reaction to this political initiative or just to a new opportunity in a world of nearly unlimited cheap foreign capital, the banks also began to provide mortgages, competing with the HF. Households began to refinance with the banks, using either foreign currency loans or index-linked ISK loans tied to the exchange rate, repaying their old ISK-denominated debt in the HF. As a result of these early repayments, the total credit from the HF to the housing market subtracted between August 2004 and February 2006 by 102 billion ISK or 21.5\%. SIC's report, supra, Volume 1, at 121. HF unexpectedly had billions of ISK in cash at its disposal but unable due to the new financing structure to redeem the bonds sold to the foreign investors. Eventually HF's capital found its way back into the housing market and the total credit from the HF to the housing market finally reached the 2004 level again in the beginning of 2008 and continued to rise. SIC's report, supra, Volume 1, at 121. [Thorvaldsson, supra note 43, at 152. - check] Not surprisingly, the cheap money available for real estate caused an explosion in real-estate prices. The real-estate price index rose from 183.1 points in January 2004 to 357.4 points in January 2008 or approximately $51 \%$. Icelandic Property Registry, Register - Iceland, www.skra.is. Additionally, increased access to capital, especially foreign capital (cheap relative to the ISK), enabled many households to finance increased consumption through new mortgages. When the crisis hit and the ISK plummeted, however, these households found themselves in a difficult position. The Institute of Economic Studies of the University of Iceland had warned against these changes and pointed to the risk of bringing those about at the same time the economy was anticipating great investment in the energy and aluminum sector as discussed below. Institute of Economic Studies: Áhrif rýmri veðheimilda Íbúðalánasjóðs á húsnceðisverð og hagstjórn, Report No. C03:06, 2003, University of Iceland.

${ }^{269}$ Revision of public surveillance of financial institutions, Committee on the revision of public surveillance of financial institutions, Minstry of Industry and Commerce, January 1998, p. 9-12 and 66-71. The structure recommended by the committee, which was enacted by law in 1999, was similar, to the ones already set-up in Sweden, Denmark and Norway, according to the committees summary and the one being set-up in the UK at the time. See also: SIC's report, supra note 174, Volume 5, chapter 16.

${ }^{270}$ Revision of public surveillance of financial institutions, supra note p. 57-59. SIC's report, supra note 174, Volume 5, chapter 15 on the regulatory framework of the Icelandic financial industry. 
2005 appointment by the prime minister of a committee, headed by Kaupthing Board Chair Sigurdur Einarsson, charged with setting out the opportunities and benefits of Iceland becoming an international financial centre. The committee identified lack of confidence in the ISK by international investors among the biggest weaknesses and economic imbalances due to currency fluctuations among the biggest threats. ${ }^{271}$ However it made no mention of the threats or weaknesses caused by the size of the Icelandic banking sector relative to its lender of last resort or the negative impact of an implicit state guarantee when the banks expanded beyond the size of the national economy.

Similarly, during the bank reforms the government paid little attention to the role of the Central Bank of Iceland or the role of the government itself as lenders of last resort. ${ }^{272}$ Neither the opening up of Icelandic borders to European capital nor the privatization of public investments funds and banks led Icelandic policy makers to contemplate whether the government's implicit backing of the banking sector might create problems. At the time there was talk of EU-membership and of the costs and benefits of being part of a larger currency area by entering the European Monetary Union. ${ }^{273}$ However, there was little discussion about whether large banks operating internationally could rely on a government with tax revenues from such a small domestic economy and a lender of last resort issuing the ISK, one of the tiniest of world currencies. ${ }^{274}$ Completely unasked was the question whether such banks, operating as private

\footnotetext{
${ }^{271}$ Prime Minister's Committee on International Financial Operations, International financial operations in Iceland, p. 10-13, October 2006.

${ }^{272}$ Willem Buiter and Anne Sibert discussed the lender of last resort theory of optimal currency areas and the Icelandic financial crisis in a paper written for Landsbanki hf. in april 2008 which was not published until October 2008 after the collapse of the Icelandic banking sector: "In April and July 2008, our Icelandic interlocutors considered our paper to be too market-sensitive to be put in the public domain and we agreed to keep it confidential. Because the worst possible outcome has now materialised, both for the banks and for Iceland, there is no reason not to circulate the paper more widely, as some of its lessons have wider relevance." Buiter \& Sibert, supra note 24, at 1. See also Gros, supra note 268. Gros discusses the importance of the issue of a lender of last resort for economies that function as global financial centres: "For example, the Swiss National Bank is increasingly concerned that the cost of support for the large global Swiss Banks might be beyond its capacity. In Luxembourg where the banking sector is even larger (compared to the local economy), the problem does not arise because Luxembourg authorities have always insisted that the subsidiaries of foreign banks have a clear owner that is also a bank so that the home country remains the lolr."
}

${ }^{273}$ See supra note 272. See also for example: Address of Prime Minister Halldór Ásgrímsson at the annual meeting of the Chamber of Commerce, February 8, 2006, available at:

http://eng.forsaetisraduneyti.is/minister/Speeches_HA/nr/2242(“The principal question is whether we will continue with our independent currency or whether we will join the European Union as full members. We must recognise that fluctuations in the króna exchange rate represent a disturbance, and the possibilities for small currencies in a free financial market are questionable. I predict that we will be full members of the European Union by 2015. The main determinant in the debate on this topic in the near future is the size and the future of the European Monetary Union."

${ }^{274}$ Buiter and Sibert, supra, note 24: "Instead it was absolutely obvious, as soon as we began, during January 2008 , to study Iceland's problems, that its banking model was not viable. The fundamental reason was that Iceland was the most extreme example in the world of a very small country, with its own currency, and with an internationally active and internationally exposed financial sector that is very large relative to its GDP and relative to its fiscal capacity." In August 2007 the Centre for Social and Economic Research (RSE) hosted a conference in Reykjavik, on Globalization and national currencies where Benn Steil of the Council on Foreign Relations discussed the end of national currencies and economist Manuel Hinds, the former Minister of Finance of Ecuador, recommended dollarization in Iceland. See for example Hinds' conference slides available at: http://multitrack.powweb.com/IcelandDollarization.ppt. See also, Benn Steil, We Need a "Safe-fail" Approach Against Crises, Financial Times, November 21, 2008, available at http://www.cfr.org/economics/we-need-safe-fail- 
financial institutions outside Iceland, should be backed by the Icelandic government. Iceland thus embarked on an era of private financial institutions with three banks with high credit ratings at least partly derived from government backing, at a time of great liquidity in global financial markets. It did so with a financial regulatory structure that subsequent experience has shown had important gaps, although this structure was based on an accepted regulatory model. And it had a deposit insurance scheme identical to those elsewhere in Europe, with deposits backed by only a modest guarantee fund.

One reason for the lack of regulatory attention to these issues during the boom was that the Icelandic economy was performing well. In constant price level (2000) terms, GDP grew from about ISK 538 billion in 1994 to ISK 785 billion in 2004, a stunning $46 \%$ increase. $^{275}$ Indeed, by 2004 Iceland ranked sixth in the world in terms of GDP per capita, behind only long established financial powerhouses (Luxembourg and Switzerland), natural resource rich economies (Norway), economic giants (the United States), and the "Celtic tiger" (Ireland) ${ }^{276}$ In short, it appeared that the reforms of the 1990s had unleashed a "Nordic tiger" economy. ${ }^{277}$ From 2004-2008 the Icelandic economy further grew by 31\%, most notably in the southwestern part of the country near Reykjavik where financial services and services generally produced GDP growth between $40-45 \%{ }^{278}$

It was not just banks, firms, and individuals who gained during the boom. The Icelandic government also reaped significant benefits from the rising ISK and growing wealth as government revenue increased substantially. ${ }^{279}$ The central government used some of this revenue to expand Iceland's Nordic-model welfare state, spending well over half its budget on social welfare (23\% in 2004), education ( $9 \%$ in 2004$)$, and health care $(27 \%$ in 2004$){ }^{280}$ It also launched an ambitious expansion of the energy sector. ${ }^{281}$ This spending occurred on at the same

approach-against-crises/p17830 ("In August 2007, former Salvadoran finance minister Manuel Hinds and I spoke out at a Reykjavik conference in favour of Iceland unilaterally "euroising". At the time, the country had more than enough foreign exchange reserves to redeem all the krona in the country for euros at the then-current exchange rate. This would not have stopped the three large Icelandic banks from overextending, but it would have prevented national financial catastrophe.") Though creating a lively discussion on the issue for a few weeks the majority of Icelandic academics, politicians and central bankers rejected the idea at the time. The EU was concerned about this problem generally.

275 Statistics Iceland: Gross Domestic Product and National Income on a Fixed Price Level 1980-2010. www.statice.is.

${ }^{276}$ Supra note 3. See also: OECD Stats Extracts. Gross Domestic Product: GDP per head, US\$, current prices, current PPPs. http://stats.oecd.org/index.aspx?queryid=556.

${ }^{277}$ Daniel Mitchell, Iceland Joins the Flat Tax Club, Tax and Budget Bulletin No. 43, February 2007, Cato Institute: "Reforms have Made Iceland a Nordic Tiger." See also Boyes, supra note 4, at 109 (using the "Nordic tiger" label).

${ }^{278}$ Dr. Sigurdur Johannesson, GDP by Regions 2003-2008, Icelandic Regional Development Institute, 2010.

${ }^{279}$ Boyes, supra note 4, at 118 ("treasury coffers had rarely been so full."). This explains the government's efforts at "selling Iceland hard" in the early 2000s. Boyes, supra, at 114-115 (describing speeches by Icelandic president and efforts by Oddsson to promote confidence in Iceland).

${ }^{280}$ Ministry of Finance, Budget 2004. Table Summary according to COFOG standard (Classification of the Functions of Government). Note absence of need for defense spending.

${ }^{281}$ In the years leading up to the boom the government planned further investment in the energy sector through its public hydro-electricity powerhouse Landsvirkjun hf. The intention was to enable foreign investment in the aluminum industry, through expansion of existing aluminum plants and the construction of a new one in the eastern 
time as spending in other sectors and in private housing was booming; private consumption between 2002 and 2007 increased around $40 \%$ in real terms ${ }^{282}$ while by 2006 construction investment reached $20 \%$ of GDP, almost levels in the U.S. and higher even than in Spain (where it reached $18 \%$ of GDP). ${ }^{283}$ The government also used the higher revenues to pay off public debt, bringing Iceland's public debt from 51\% of national GDP in 1995 to $36 \%$ in 1999, and below $20 \%$ in September $2005 .^{284}$ Thus even while the central government was paying down its debts and lowering taxes, its expenditure increased significantly during the boom years. This increased the strains on the economy. ${ }^{285}$

The growth, the strengthened currency, and the increased imports led the Icelandic Central Bank to raise interest rates repeatedly from 5.3\% in early May 2004 to 15.5 by the eve of the fall of the banks in an effort to slow demand domestically. ${ }^{286}$ While Icelandic interest rates were rising, interest rates elsewhere in the developed world remained at record lows. The real interest rate in the UK was $1.8 \%$ while in the United States it was $1.4 \%{ }^{287}$ In addition, the simultaneous strengthening of the ISK against the dollar, pound, euro, yen, and other currencies meant that real yields in ISK-denominated assets were even higher, since the currency appreciation added to the return. What the Icelandic central bank did was standard operating

part of the country. The latter project was at the time believed to be the largest construction project in the history of Iceland, estimated in February 2003 to cost ISK 186 billion (price reference year 2002, which amounted to US\$ 2.4 billion at February 2003 exchange rates). Central Bank of Iceland. Monetary Bulletin 2003/1, Appendix: Evaluation of the macroeconomic impact of the planned aluminium and power plant investments and possible economic policy responses to them., According to the Central Bank of Iceland the cost related to the power plant, borne by Landsvirkjun was estimated at ISK 95 billion and the cost of building the plant borne by the aluminum giant Alcoa was estimated at ISK 91 billion. This project, which sparked controversy from the onset, was the product of a government anxious to ensure continued economic growth. The Central Bank of Iceland warned against the inflationary pressures the project could create and emphasized the importance of fiscal policy measures alongside monetary policy measures to maintain balance in the economy. Id. At the time the Central Bank did not anticipate the great expansion of the liberalized financial sector and the great inflow of capital so in its warnings made no mention was of the trends of governments and central banks of the world's largest economies and the possible consequences of their policies on global financial markets.

The aluminum projects' impact in Iceland did add to the inflationary pressures during the boom years. While the power plant - termed Kárahnjúkavirkjun - and the aluminum structure of Alcoa in the east were being built, Century Aluminum's plant in the West was being enlarged, and two other public energy companies Orkuveita Reykjavikur (owned by the municipality of Reykjavik and a few other surrounding municipalities) and Hitaveita Sudurnesja (owned by the municipalities in the South West) were as well investing in their power plant capacity. SIC's report, supra note 174 , Volume 1 , at 80.

${ }^{282}$ SIC's report, supra note 174 , Volume 1, at 80.

${ }^{283}$ Gros, supra note 268, at 6.

${ }^{284}$ SIC's report, supra note 174, Volume 1, at 100; Thorvaldsson, supra note 43, at 150. Local government debt nearly tripled between 1998 and 2008 partly as a result of decentralization of projects from central government to local government, but more notably because of the leveraged investments made by the local municipalities (often in foreign currency). SIC's report, supra note 174, Volume 1, at 100-101.

${ }^{285}$ SIC's report, supra note 174, Volume 1, at 129 (The SIC notes that fiscal policy during the boom years of 20042007 was insufficient to meet the challenges created by the booming economy).

${ }^{286}$ Central Bank of Iceland at www.sedlabanki.is, Central Bank Interest Rate (Loans against a collateral (nominal rate) / Repo rate (yield)).

${ }^{287}$ World Bank, Real Interest Rates available at

http://data.worldbank.org/indicator/FR.INR.RINR/countries/1W?page=1\&display=default 
procedure for a central bank under a floating exchange rate monetary regime. Faced with an overheating domestic economy, the conventional wisdom was that a central bank in an open economy should raise domestic interest rates. ${ }^{288}$ In theory, the higher interest rates would then slow domestic demand. ${ }^{289}$ However, the impact of the Icelandic Central Bank's rate increases was quite different from what the theory predicted, as domestic demand increased during those years, as mentioned earlier, despite repeated interest rate hikes. ${ }^{290}$ Why did this happen?

One reason was that the efficiency of the central bank policy's transmission mechanism had limited effect on domestic demand, since the overwhelming majority of household debt was either in the form of ISK consumption index-linked mortgages with fixed interest rates, usually to a 25-40 year bond, where interest and index-linked payments were spread over the loan period, or denominated in a foreign currency. In both cases, the debt was not directly affected by the central bank's interest rate hikes. ${ }^{291}$ Similarly, business debt was increasingly in foreign-

${ }^{288}$ See, e.g., OECD Economic Outlook 200194 (2001) ("The Central Bank [of Iceland] should show caution in cutting its interest rates, since it is crucial to build confidence in the current level of the exchange rate in order to prevent the spike in inflation from being reflected in wage demands.")

289 The Icelandic central bankers have since argued that the floating exchange rate monetary policy was never fully functional. They have pointed to several mistakes in the implementation of the policy. First, they argue that the transition to the floating exchange rate came about during a 2001 attack on the ISK by speculators and that the central bank basically fled the fixed exchange rate policy to a floating exchange rate policy instead of making a thoroughly planned and studied policy change. Interview with Thorarinn G. Petursson chief economist at the Central Bank of Iceland, which was the Head of the Department of Economics at the bank when the floating exchange rate policy was introduced. (Our translation) SIC's report, supra note 174, Volume 1, at 131. He also stated in the interview (Our translation): "We had suggested a few years earlier [prior to 2000] that we shifted to this [policy] since it was the only option. Then we come to the point that nothing is being done and the system just blows up and then we just have to do something, a decision has to be made. Of course we would have wanted it a much more developed financial system and all, but it just was our only option. I think that the financial system was only moderately developed to support it." Second, they contend that that the technical execution of the policy, especially in regard to the interest rate decision making process, was seriously flawed. Interview with Thorarinn G. Petursson chief economist at the Central Bank of Iceland, which was the Head of the Department of Economics at the bank when the floating exchange rate policy was introduced. (Our translation) SIC's report, supra note 174, Volume 1, at 135. He admitted that the interest rate decision mechanism of other central banks operating same policies had not been studied: "[...] we in the economics department did time and again comment on the technical execution [of the interest rate decisions] which has been a mess." SIC further noted in its report at page 140 that "the technical execution of the transmission mechanism fell short of being adequate. The Central Bank had no interest rate target. It did not try to evaluate the demand for liquidity within the system." Third, they argue that the interest rate hikes were always "behind the curve" and that they were thus 'too little, too late'. Interview with Thorarinn G. Petursson chief economist at the Central Bank of Iceland, SIC's report, supra note 174, Volume 1, at 155. The Althingi's research committee agrees with this view, see SIC's report, supra, Volume 1, at 140-141.

${ }^{290}$ See Guillaume Plantin \& Hyun Song Shin, Carry Trades, Monetary Policy and Speculative Dynamics, 4 (Jan. 2011) available at http://www.imf.org/external/np/seminars/eng/2011/res2/pdf/gp.pdf (“As Iceland raised interest rates in response to the overheating economy, the higher interest rate differential attracted capital inflows that fuelled the investment boom that exacerbated the overheating economy. The inflation-targeting central bank raised interest rates further in response, giving a further twist to the vicious circle of an appreciating exchange rate and further capital inflows.")

${ }^{291}$ In mid-2008, 65\% of the 967 billion ISK household debt in the Icelandic banks (out of approx. 1760 billion ISK in total household debt), or 626 billion ISK, was in index-linked króna. Further $22 \%$ of the household debt in the banks, or 210 billion ISK, were denominated in foreign currency. Minstry of Finance's Online Magazine, October 16, 2008, on houseld debt, available at http://www.fjarmalaraduneyti.is/almennar_frettir/2008/10/20/nr/11440. One can therefore conclude that the CBI's transmission mechanism directly affected less than 13\% of the houehold debt within the Icelandic banks. . 
currency-denominated loans, mainly due to the cost of funding in the high interest rate ISK, which again limited the impact of the interest rate hikes. The problem was not limited to the lessened effectiveness of interest rate hikes, however. Currency trading, what became known as the carry trade, also had an impact. Big corporations and even sovereigns with strong credit ratings, such as Toyota, the Norwegian Eksportfinans and the Republic of Austria, were able to borrow euros at lower rates through issuance of bonds denominated in ISK (known as "Glacier Bonds"). ${ }^{292}$

The currency carry traders seemed to be on a sure bet, at least during the good years. They shifted their clients' money from low-interest countries such as Japan and parked it in Iceland, with its extraordinarily high rates. That boosted the money available to Icelandic banks for investment abroad. Borrow low, lend high: it was a simple enough concept. Speculators borrowed in Japan at 3 percent-and lent in markets such as Britain, New Zealand, or Iceland with higher interest rates. Iceland with its 15 percent rates — kept high to control inflation-was particularly attractive. $^{293}$

Approximately 152 billion ISK in Glacier bonds had been issued by the end of 2005; the outstanding amount reached 450 billion ISK in September 2007 or approximately $35 \%$ of Iceland's GDP. ${ }^{294}$ This increased the demand in ISK and in Icelandic government bonds. The investors demanded ISKs from currency markets and delivered them to the broker who typically swapped them with the Icelandic banks for euros, and provided the issuer of the Glacier bonds with the euros the issuer needed. The Icelandic banks had borrowed the euros in international financial markets and then put the ISK to work by lending it to Icelandic companies and households. The price of the ISK soared. ${ }^{295}$

292 This was usually through a broker, which earned handsome fees by selling the bonds to international investors looking for higher yields on their investment. SIC's report, supra note 174, Volume 1, at 149-153.

The Glacier Bond issues were actually driven by other financial institutions than those issuing the bonds, the most famous being the Canadian bank, Toronto Dominion. They would approach banks with AAA credit ratings, the highest possible, like Rabobank and the European Investment Bank, with a proposition to secure them funds at lower rates than they were getting through normal funding routes. Toronto Dominion (quite legitimately) would sell kronur denominated bonds with a high interest rate, issued by AAA banks, that were snapped up by the yield hungry dentists. The issuing banks had of course no interest in having debt outstanding in kronur as they had no assets in Iceland. The Canadians thus also entered so-called swap agreements with the banks, effectively converting their liability from kronur to other currencies, typically euros. Toronto Dominion then entered into the opposite swap with one of the Icelandic banks to hedge their own position. Because the bonds were sold to the private investors at interest rates slightly lower than those prevailing in Iceland (but still high compared to what they would get in other currencies), the likes of Rabobank ended up paying lower interest in euros than they would have, if they sold euro bonds directly. The Canadian bank took fees for arranging the bond issue and some margin on the swap agreements, and made a fortune.

Thorvaldsson, supra note 43, at 153.

293 Boyes, supra note 4, at 88-89.

${ }^{294}$ SIC's report, supra note 174, Volume 1, at 150.

${ }^{295}$ SIC's report, supra note 174, Volume 1, at 149-153. 
While the transmission mechanism of the Central Bank's monetary policy was not working as theory had predicted, it did work in an unintended way through the exchange rate. Focused on their inflation target, the central bankers in Iceland deliberately sought to maintain a strong ISK. ${ }^{296}$ Higher Icelandic interest rates meant money was drawn into ISK-denominated assets, primarily via Glacier bonds. As money poured in from abroad, the ISK strengthened and Icelanders' ISK-denominated wealth relative to other currencies increased. Icelanders then imported more, not less, driving the Central Bank to further raise domestic interest rates in an effort to address the balance of payments. These increases only enhanced the attractiveness of ISK-denominated assets, drawing even more money into ISK-denominated investments. Moreover, because of the ease of investing across borders made possible by the reduced transactions costs of the global economy, it was not just large investment firms that put money into ISK-denominated assets but also individual investors from Belgium to Japan. And Icelanders had an incentive to continue to borrow in foreign-currency denominated loans. ${ }^{297}$ The Central Bank was aware of this impact and of the risks it posed. ${ }^{298}$

A final factor drawing investors to Iceland was the growth of international investment funds attempting to diversify geographically. Because Icelandic assets were a relatively new addition to the marketplace (since pre-reform Iceland had not been an inviting investment climate) and because Icelandic assets were performing well, there was demand for ISKdenominated securities. Because of Iceland's small market, there were relatively few assets available with which to meet this demand and investors looking for Icelandic assets bought the small number of Icelandic stocks (primarily banks and holding companies).

Iceland's boom involved a dramatic increase in the size of Iceland's financial institutions but not much of a change in Iceland's financial regulators. Icelandic firms and Icelandic banks, often interlocking entities, expanded across Europe and North America. They were able to do so for three reasons. First, Icelanders, Icelandic firms, and Icelandic banks had access to cheap capital, as a result of the dramatic increase in global liquidity. Second, people outside Iceland wanted to invest in Icelandic firms and banks because the rising ISK and high interest rates made Icelandic investments attractive relative to other investment opportunities. The attractiveness of these investments was also due to the investments' excellent credit ratings, which in turn were partially derived from the implicit guarantee by the Icelandic government of the Icelandic banks. Both of these were made possible by the floating nature of exchange rates against the ISK and the international financial framework ensuring the free movement of capital that had become the financial landscape by the 1990s. Third, regulators in Iceland, Europe, and North America all failed to anticipate problems with the Icelandic economy. The problem was not a lack of regulatory tools, regulatory power, or regulatory authority. Nor was the problem that no one knew what was happening in Iceland - everyone knew about the Icelandic boom. It was literally

\footnotetext{
${ }^{296}$ For example, in its March 2005 Monetary Bulletin the Icelandic Central Bank stated: "The exchange rate is an important part of the transmission mechanism of monetary policy in an open economy. In the present economic climate, it is an extremely effective channel. Were it not available, monetary policy would be muted by the current global climate in financial markets." This is cited by SIC's report, supra note 174, at 147.

${ }^{297}$ Boyes, supra note 4, at 5 ("Credit, denominated in exotic currencies, was always available" in Iceland during the boom).

${ }^{298}$ SIC's report, supra note 174, at 153 (Thorarinn G. Petursson chief economist at the Central Bank of Iceland, stated in an interview: "We were conscious of [...] the consequence of this [the Glacier bonds effect, BTP ins.], it would strengthen the exchange rate $[\ldots] "$.)
} 
impossible to miss, with high profile purchases of expensive corporate assets by Icelandic firms. ${ }^{299}$ Regulators needed only a subscription to the Wall Street Journal to know that there was an Icelandic boom. ${ }^{300}$ Everyone in Iceland was aware of the booming economy. To what extent the Icelandic authorities anticipated the problems it could create is less clear. If they hadn't known before, however, they certainly could have known that something big was happening when the "Geysir" crisis hit in 2006.

\section{The Geysir Crisis}

Investors' appetites for ISK-denominated assets began to reach their limits in early 2006, not in response to regulators' actions but because of market actors' identification of problems. On February 212006 Fitch downgraded the Icelandic government's ratings, stating that: "The Negative Outlook has been triggered by a material deterioration in Iceland's macro-prudential risk indicators, accompanied by an unsustainable current account deficit and soaring net external indebtedness." ${ }^{301}$ On March 7 Merrill Lynch issued a report on the Icelandic banks stating: "We are only at the beginning of the Icelandic banks' problems." 302 On March 21 a report by Danske Bank analysts raised serious questions about the developments in the Icelandic economy:

On most measures, the small Icelandic economy is the most overheated in the OECD area. Unemployment stands at $1 \%$, wage growth is above $7 \%$ and inflation is running above $4 \%$ despite a strong ISK. The current account deficit is closing in on $20 \%$ of GDP. The Icelandic central bank has been hiking rates substantially in order to cool the economy, and rates are now above $10 \%$. Based on the macro data alone, we think the economy is heading for a recession in 2006-7. GDP could probably dip $5-10 \%$ in the next 2 years, and inflation is likely to spike above $10 \%$ as the ISK depreciates markedly.

However, on top of the macro boom, there has been a stunning expansion of debt, leverage and risk-taking that is almost without precedents anywhere in the world. External debt is now nearly $300 \%$ of GDP, while short term external debt is just short of $55 \%$ of GDP. This is $133 \%$ of annual Icelandic export revenues.

\footnotetext{
${ }^{299}$ Griffiths, supra note 4.

${ }^{300}$ See, e.g., Gissurarson, supra note 201, Miracle on Iceland, WALL STREET J. (Jan. 24, 2004).

${ }^{301}$ Central Bank of Iceland, Fitch Ratings Revises Iceland's Outlook to Negative, Feb. 21, 2006 available at http://www.sedlabanki.is/?PageID=287\&NewsID=1124 (reprinting Fitch ratings release in which Paul Rawkins, Senior Director in Fitch's Sovereign team in London, states that "public finances continue to go from strength to strength - general government debt is forecast to fall to $25 \%$ of GDP in 2006 - underpinning the sovereign ratings. However, the rest of the economy is significantly indebted now: credit to the private sector - much of it price or exchange rate linked - stood at an estimated $218 \%$ of GDP at end-2005, having doubled in three years. Yet Icelandic banks and corporates continue to pursue ambitious expansion plans abroad, accumulating external debt at an unprecedented rate in the process.") In Fitch's Bank Systemic Risk Report published on February 6, 2006, it had as well raised concerns for the Icelandic banking sector.Mark J. Flannery, Iceland's Failed Banks: Post-Mortem, prepared for the SIC in November 2009, SIC's report, Volume 9, at 97, available at http://sic.althingi.is/pdf/RNAvefVidauki3Enska.pdf., (citing Fitch's report: "The credit boom in Iceland gives most cause for concern.")

${ }^{302}$ Richard Thomas, Icelandic Banks: Not what you are thinking, Merrill Lynch, February 21, 2006, http://www.scribd.com/doc/19606822/Merrill-Lynch-Icelandic-Banks-Not-What-You-Are-Thinking.
} 
We look at early warning indicators for financial crises and conclude that Iceland looks worse on almost all measures than Thailand did before its crisis in 1997, and only moderately more healthy than Turkey before its 2001 crisis. ${ }^{303}$

The report went on to predict that the cost of capital would rise for the Icelandic banks and that this would result in a "funding squeeze" that would lead to reduced lending and a sell off of external assets. ${ }^{304}$ As predicted, funding through bond markets did become increasingly difficult for the Icelandic banks as these concerns spread, especially in Europe. ${ }^{305}$ After years of almost throwing money at Icelandic firms and Icelandic investors, investors suddenly became more cautious.

Three additional factors also created unease among at least some analysts and investors about the Icelandic economy. ${ }^{306}$ First, as noted above, by 2006 , the biggest Icelandic business tycoons had become major shareholders in the banks that financed their businesses, in addition to holding stakes in the largest businesses in the country, ${ }^{307}$ which owed the banks money. These cross-shareholdings worried some analysts and investors as a sign of potential trouble - if Investor A guaranteed his loan from Bank B with his holdings in Firm C, while Firm C bought Bank B's stock with the proceeds of its sale of stock to Investor A, there was a disturbing amount of circularity involved in the rising price of Bank B and Firm C's stocks. ${ }^{308}$ Second, a lack of transparency in Iceland, where a closely knit group of people seemed to control most of its business sector, created unease in some of the neighboring countries. ${ }^{309}$ Third, for all its impressive economic performance, Iceland remained a tiny economy with a tiny currency base. Iceland's fundamentals may have been strong, but it was small and highly leveraged and a comparison of Icelandic firms and Icelandic GDP suggested to foreign analysts that there were problems ahead. This included the OECD, which took notice of the potential for trouble in a

\footnotetext{
${ }^{303}$ Iceland: Geyser Crisis, Danske Bank, 21 March 2006.

${ }^{304}$ Iceland: Geyser Crisis, Danske Bank, 21 March 2006.

${ }^{305}$ Thomas, supra note 302, at 5 ("the European bond markets effectively closed to the Icelandic banks even before the February volatility.")

${ }^{306}$ The first negative credit report (by RBS) appeared on Kaupthing in mid-November 2005. Thorvaldsson, supra note 43, at 171. See Royal Bank of Scotland, Kaupthing Bank, FIXED InCOME CREDIT RESEARCH (23 Nov. 2005) available at https://notendur.hi.is/ajonsson/kennsla2010/RBS.pdf.

${ }^{307}$ This was highlighted quite spectacularly in SIC's report, supra note 174, in Volume 9, Appendix 2, Research on the Cross-holdings and bank lending to related parties, p. 9-91. See also Thorvaldsson, supra note 43, at 237 (discussing cross-holdings).

308 JP Morgan's analysts addressed these cross-holdings in their report on the Icelandic banks on March 24, 2006. JP Morgan, Icelandic Banks: Typical Investor Q\&A and our response, EUROPEAN CREDIT RESEARCH (24 March 2006) at 5 ("in terms of big risks to the banks themselves, we think they are (assuming the funding holds) the crossholdings and related party and equity based lending. Given the small domestic market, it is perhaps not surprising that there is some level of cross-holdings among the major investment companies, corporates and banks, but we are surprised at the level.").

${ }^{309}$ Merrill Lynch noted in its report on March 7, 2006 that "As such, while we acknowledge that banks have diversified their revenue sources by expanding abroad, the risks faced in the domestic market are far from negligible, and have been compounded by a complex system of cross shareholdings and nominee accounts which make the true risks faced by these banks difficult to quantify." Thomas, supra note 302, at 7.
} 
survey published in August 2006. ${ }^{310}$ Since the Icelandic banks' and firms' business models involved considerable short-term borrowing on wholesale markets, these developments posed a threat to the banks' and firms' abilities to roll over their liabilities. ${ }^{311}$ The resulting fall in demand for Icelandic assets led to rising interest rate costs for Icelandic firms and signs of weakening in the ISK.

Icelanders and Icelandic firms responded mainly in three ways to this "mini-crisis." First, together with key politicians and other influential people in Icelandic society, the Icelandic business sector launched a campaign to reassure investors through the international press, emphasizing the foundations of wealth in Iceland and assuring the creditors that all was well. ${ }^{312}$ Second, as previously noted, when European bond-markets seemed all but closed Icelandic banks sought funding into US bond markets, which welcomed highly rated, high interest bonds for use in collateralized debt obligations. ${ }^{313}$ Third, the Icelandic banks created new high interest internet accounts that drew in substantial deposits from outside Iceland, which improved the banks' balance sheets and which included ordinary savings accounts, a longer term savings

${ }^{310}$ Although noting that Iceland's economic growth had been "impressive," the OECD report raised a number of concerns about the future:

[t]his enviable growth performance has, however, been marred by high demand and output volatility and recurrent sizeable macroeconomic imbalances, which have tended to increase. The current level of excess demand is larger than in the previous boom in the late 1990s. The same is true for the current account deficit, which at 16 $\frac{1}{2}$ per cent of GDP in 2005 is easily the highest in the OECD. At the same time, households and firms, in particular banks, have become highly indebted. Concerns about these developments have recently led to considerable financial market turbulence. The exchange rate and stock prices dropped sharply earlier this year, though from historically high levels. With rising import prices and capacity pressures in goods and labour markets, inflation has reached 8\%. Excess demand not only reflects large-scale aluminum-related investment projects, but also surging household spending (on both consumption and housing). With hindsight, the response of macroeconomic policies to signs of overheating was insufficient. Secretariat projections suggest that, despite a slowdown in domestic demand due to higher interest rates and the gearing down of the investment projects, inflation pressures and external deficits will remain substantial in the near term. The recent wage agreement is intended to reduce uncertainty about the inflation outlook but will increase inflation in the short term. Against this backdrop, further currency depreciation and an additional build-up of inflationary pressures cannot be excluded, implying a harsher adjustment process.

Economic survey of Iceland 2006, OECD Policy Brief, July 2006, at page 3-4. http://www.oecd.org/dataoecd/22/45/37215813.pdf

311 JP Morgan noted in its March 24, 2006, report at page 5: "the reliance on the wholesale market and the shortterm nature of their funding is a serious flaw in their business models. [...] while funding appears supported in the short term we still think that a material risk is that funding problems can become a self fulfilling prophesy"

${ }^{312}$ Frederic S. Mishkin \& Tryggvi Thor Herbertsson, Financial Stability in Iceland, Iceland Chamber of Commerce, May 2006, http://www.vi.is/english/publications/reports/. Boyes, supra note 4, at 125 (noting that "Landsbanki issued a detailed rebuttal [of the Den Danske Bank report]; so did the other Icelandic banks and most of the political class.")

313 See note 258 supra. 
account, and fixed rate bonds. ${ }^{314}$ These responses proved effective and "[ $\left.\mathrm{t}\right]$ he credit agencies "made their peace with Iceland." 315 The crisis seemed to be over.

The funding of the Icelandic banks through European internet bank depositors highlights an important flaw in the regulatory framework of the European financial markets. The move was in part a response to international criticism of the lack of diversified funding strategies of the banks and, as Asgeir Jonsson points out, "was applauded by rating agencies and credit analysts alike" $" 316$ even as it created considerable risk in the event of an international liquidity crisis. ${ }^{317}$ The banks each created subsidiaries or branches seeking deposits outside Iceland for ISKdenominated accounts. Two of these subsidiaries (Edge and Save \& Save) were created as U.K.chartered subsidiaries of the Icelandic parents (Kaupthing and Glitnir, respectively). ${ }^{318}$ One (Icesave) was created as an Icelandic branch of its parent (Landsbanki), a distinction that proved crucial in the crisis. These efforts proved particularly successful in Britain. As Boyes describes it:

Barely any British institution was untouched by the Icelandic financial system. Oxford University deposited 30 million GBP into Landsbanki, Glitnir, and KSF. The Metropolitan Police - the authority that controls Scotland Yard — invested another 30 million GBP; the Sussex Police Authority, 6.8 million GBP. Transit for London, 40 million GBP; Cambridge University, 11 million GBP; the National Cat Protection League, 11.2 million GBP; 116 local governments poured 858 million GBP into Icelandic banks. Three hundred thousand individual British were Icesave depositors. Gordon Ramsay, the foulmouthed master chef, turned to Kaupthing to refinance a loan. Fire departments and churches put their trust in Icelandic investment funds. So, embarrassingly, did the Audit Commission, the body monitoring public spending, which was later called on to investigate what went wrong with the British. ${ }^{319}$

In the Netherlands, Icesave took in $€ 1.7$ billion from 125,000 customers in just five months, again as an Icelandic branch. ${ }^{320}$ The results were spectacular in terms of the banks' deposit ratios (the ratio of deposits to loans) -Kaupthing improved from a $29.6 \%$ ratio at the end of 2006 to

\footnotetext{
${ }^{314}$ SIC's report, supra note 174, in Volume 6, chapter 18. Boyes, supra note 4, at 127 (describing creation of internet banks to lure deposits from Britain, the Netherlands, and Germany); id. at 133 (describing account types).

315 Boyes, supra note 4, at 146. On April 4, 2006 Moody's published a report on Iceland and its author Joan Feldbaum-Vidra said: "While we have warned of the risks that may accompany increased leverage in the economy, Iceland has our top rating with a stable outlook, and we believe these concerns have recently been exaggerated." Moody's Investor Services, Iceland's Solvency and Liquidity are Not at Risk, Supecial Comment (April 2006) available at http://www.mbl.is/media/11/411.pdf.

316 Jonsson, supra note 24, at 124 (Jonsson stated that "there was a strange disconnect between the ratings agencies, banking analysts and sovereign analysts. Whereas the banking analysts applauded Icesave, the sovereign analysts took no note of the increased contingent liability of the state through its deposit guarantee.").

${ }^{317}$ SIC's report, supra note 174, in Volume 5, p. 224.

${ }^{318}$ Boyes, supra note 4, at 133 (describing difference in locations of subsidiaries) See also SIC's report, supra note 174 , Volume 5 p 223-224.

319 Boyes, supra note 4, at 127.

${ }^{320}$ Boyes, supra note 4 at 133. SIC's report, supra note 174, Volume 5, p. 223-224.
} 
$36.7 \%$ at the end of 2007, while Landsbanki's ratio went from $47.5 \%$ to $70.3 \%$ during the same period. $^{321}$

Landsbanki's Icesave accounts in the UK and the Netherlands posed the greatest threat, because they were set up as branches of the Icelandic parent bank, not as subsidiaries in the UK and Netherlands. This arrangement created jurisdictional uncertainty in financial surveillance; more importantly, it meant that the approximately 400,000 foreign depositor accounts were backed only by the tiny Icelandic Deposit and Investors' Guarantee Fund. ${ }^{322}$

Why did so many non-Icelandic depositors put money into Icelandic banks' internet accounts? One reason is that the cost of banking outside their home country had fallen dramatically; in some respects it has become easier to bank online than at a traditional bricks and mortar branch. ${ }^{323}$ Second, the Icelandic banks offered high rates, Landsbanki's Icesave deposit accounts ranked number one on the UK best buy tables for internet banks for a large part of the year 2007. ${ }^{324}$ Finally, most depositors did little investigation into the soundness of the banks where they were placing money, even when the amounts in question were large. The post-crisis inquiry into British public authorities use of Icelandic accounts suggested that many relied solely on guidance from rating agencies. ${ }^{325}$

By the fall, the Geysir crisis had passed and financial indicators like CDS spreads were improving so that "[a]s 2006 drew to a close, the memories of the Geyser crisis had rapidly faded." ${ }^{, 326}$ As it turned out, serious problems remained unaddressed. In its report, the SIC concluded that to prevent the downfall of the Icelandic banks, regulators should have intervened no later than in $2006 .{ }^{327}$ However, instead of pursuing policies like urging the banks to downsize their balance sheets and especially their foreign exposure or to move their headquarters from Iceland and so bring themselves under larger insurance funds in other countries, the Icelandic government emphasized Iceland's role as a financial center and the further expansion of the Icelandic corporate sector abroad. ${ }^{328}$

\footnotetext{
${ }^{321}$ Boyes, supra note 4, at 146. SIC's report, supra note 174, Volume 5, p. 223-224.

322 This fund was created as a result of EU Directive 94/19/EC on Deposit Guarantee Schemes, set up to increase the stability of the European banking system and protection for savers, doing neither as it turned out in the event of a financial meltdown. Directive 94/19/EC: http://eurlex.europa.eu/LexUriServ/LexUriServ.do?uri=CELEX:31994L0019:EN:HTML. The objectives of the directive are so described in the directive's preamble: "Whereas, in accordance with the objectives of the Treaty, the harmonious development of the activities of credit institutions throughout the Community should be promoted through the elimination of all restrictions on the right of establishment and the freedom to provide services, while increasing the stability of the banking system and protection for savers;"

323 Jonsson, supra note 24 , at 124.

${ }^{324}$ SIC's report, supra note 174, Volume 6, at 17. http://www.moneysorter.co.uk/best_buy_internet_bank.html.

${ }^{325}$ See Boyes, supra note 4, at 135.

326 Thorvaldsson, supra note 43, at 174.

327 SIC's report, supra note 174 , Volume 1, at 32.

${ }^{328}$ SIC's report, supra note 174, Volume 1, at 32. The report notes that regulators, such the Financial Surveillance Authority (the FME) were authorized by law to intervene, for example by increasing capital requirements demands, but chose not to do so. SIC's report, supra, Volume 1, at 34. The ARC points out that the government did first and foremost focus on stimulating economic growth and thus neglected the dangers of an oversized banking sector in relation to the Icelandic economy.
} 


\section{E. The Meltdown}

Although Iceland had survived the Geysir crisis, there remained strong indicators that all the problems had not been resolved. The SIC found that after the Geysir crisis the banks' lending to related parties and cross-holding risks increased substantially, making a hard landing become inevitable when the global liquidity crisis hit. ${ }^{329}$ It also found that the banks did support their owners to a far greater extent than reasonable. ${ }^{330}$ Decreasing global liquidity in financial markets in 2007 meant the Icelandic banks refinancing problems grew, as they needed to refinance $€ 2$ billion in bonds maturing in late 2007 and $€ 3$ billion in $2008 .{ }^{331}$ And though Icelandic regulators may have had the legal tools to take necessary action the task may have been impossible, effectively illustrated in Figure 1, made by the SIC's researchers:

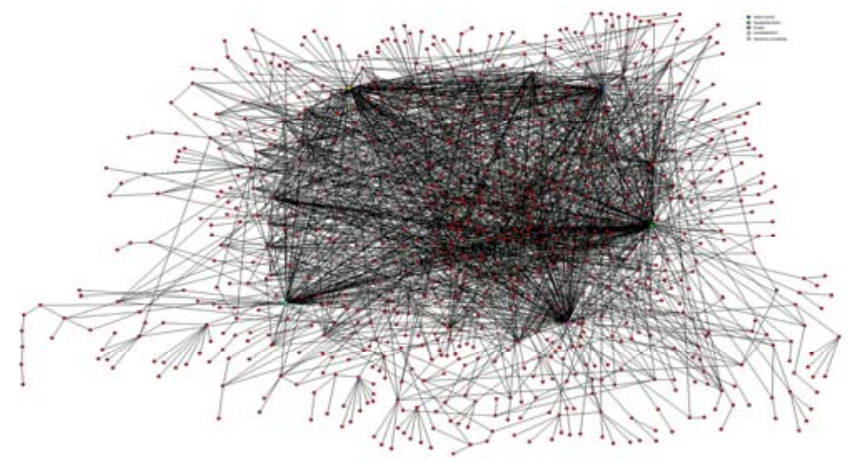

Picture 1: Ownership-relations of Icelandic companies with more than 500 million ISK in assets. ${ }^{332}$

The Icelandic financial sector was thus highly sensitive to defaults of the key players or drops in stock prices. $^{333}$

These problems did not go unnoticed. "Robert Aliber, a University of Chicago specialist on financial crises, became fascinated by the Icelandic bubble. In 2007 he drove around the capital counting the excessive number of building cranes and warned in a public speech, 'You've got a year before the crisis hits.",334 New Zealand economist Robert Wade, an expert on the 1997 Asia financial crisis, visited Iceland in 2007 and also warned of trouble ahead. ${ }^{335}$ Hedge fund managers visited Iceland for a raucous January 2008 meeting to discuss shorting Icelandic

\footnotetext{
${ }^{329}$ SIC's report, supra note 174 , Volume 1, at 32.

${ }^{330}$ SIC's report, supra note 174 , Volume 1, at 32-34. The ARC notes for example that the three banks had lent to Baugur Group and related parties, at its peak, some 5,5 billion Euros representing 11\% of the total combined claims of the banks, and $53 \%$ of their capital requirements.

331 SIC's report, supra note 174, Volume 1, at 35-36.

${ }^{332}$ Margrét V. Bjarnadóttir and Guðmundur Axel Hansen, Cross-ownership and related party lending, SIC's report, supra note 174, Volume 9, at 23.

333 SIC's report, supra note 174, Volume 1, at 32-34.

${ }^{334}$ Boyes, supra note 4, at 154. In SIC's report, supra note 174, Volume 8, at 225-226, an account is given of Aliber's talk at the University of Iceland during his visit in 2007 and the mixed response to his analysis and predictions at the time. Robert Aliber made some policy recommendations to Iceland in a paper he presented on June 20, 2008. By then it was too late. See: http://www.hi.is/files/skjol/icelandlecutre-May-2008.pdf

${ }^{335}$ Boyes, supra note 4 , at 154 .
} 
assets; ${ }^{336}$ credit default swap spreads on Iceland widened from summer 2007 to March 2008; Moody's downgraded the Icelandic banks; $;{ }^{337}$ London School of Economics professor and Financial Times columnist Willem Buiter warned of a possible run on the banks in an April 2008 paper for Landsbanki (which the bank kept confidential) and so did CEPS' Daniel Gros, as noted earlier. $^{338}$ Not all the evaluations were negative, a July 2007 UBS “Credit Analyzer" speculated that Icelandic banks might escape some of the global turmoil because of their lack of subprime $\operatorname{assets}^{339}$ and in January 2007 Moody's had given the Icelandic banks its AAA rating. ${ }^{340}$

To meet their refinancing needs the Icelandic banks began to drawing on short term credit lines with central banks against collateral, in addition to raising capital through their internet banking operations. These loans stood $€ 2$ billion in 2007 (mostly from the Central Bank of Iceland) but had grown to a total $€ 9$ billion by October 2008 (little less than a half from the European Central Bank). ${ }^{341}$ These loans from the Central Bank of Iceland grew from 30 billion ISK in 2005 to 500 billion ISK when the banks collapsed (€407.6 million to $€ 6,793.3$ million) ${ }^{342}$. While the central banks were acting as lenders of last resort for the banks, the Icelandic banks seemed to be operating as lenders of last resort for their owners, Icelandic investors, and even foreign investors in need of funds. In this respect the SIC points out that in the latter half of 2007 loans to foreign parties - some of which were actually of Icelandic origin but registered abroad and so recorded as "foreign" - increased by $€ 11.4$ billion, at a time when the banks faced their own liquidity crises. ${ }^{343}$ By 2008 , the Central Bank of Iceland began to experience its own problems. On April 23, 2008 Mervyn King, governor of the Bank of England, rejected the CBI's request for a currency swap agreement. ${ }^{344}$ The SIC states that after the central bank governors meeting at the G-10 in Basel on May 4 in 2008 it was quite clear that, with the exception of the central banks of Sweden, Norway and Denmark, no-one was willing to lend money to the CBI. ${ }^{345}$

When the first rumblings of the subprime crisis in the United States began-ironically, the Icelandic banks had little exposure to U.S. subprime assets themselves -Icelandic banks and

\footnotetext{
336 Thorvaldsson, supra note 43, at 187.

337 Thorvaldsson, supra note 43, at 187; CDS on Icelandic Banks Rises on Moody’s Downgrade, Reuters (Feb. 28, 2008) available at http://uk.reuters.com/article/2008/02/28/icelandicbanks-ratings-idUKL2862408320080228.

${ }^{338}$ Buiter and Sibert, supra note 24, at 1 and Gros, supra note 268.

339 Thorvaldsson, supra note 43, at 178-179; UBS Investment Research, Icelandic Banks: A question of risk reward (Dec. 5, 2007) available at https://notendur.hi.is/ajonsson/kennsla2006/Icelandic\%20banks\%20initiation\%20SAed.pdf.

340 SIC's report, , supra note 174, Volume 2, at 13. The Royal Bank of Scotland „,blasted“ Moody“s for the ratings of the Icelandic banks in February 2007. See Bloomberg's John Glover February 26, 2007 : http://www.bloomberg.com/apps/news?pid=newsarchive\&sid=aFU1Ddtg2k8M\&refer=home. Moody’s stock prices fell $6 \%$ the same day, and the agency downgraded the Icelandic banks to Aa3 in April same year. SIC's report, supra note 174, Volume 2, p. 13. Thorvaldsson, supra note 43, at 254.

${ }^{341}$ SIC's report, supra note 174, Volume 1, at 35-36.

${ }^{342}$ SIC's report, supra note 174, Volume 1, at 35. Calculated via xe.com using Oct. 1, 2005 exchange rates.

${ }^{343}$ SIC's report, supra note 174 , Volume 1, at 36-37.

${ }^{344}$ SIC's report, supra note 174, Volume 1, at 41. The SIC notes that Mervyn King offered his assistance to decrease the size of the Icelandic banking sector abroad, an offer not accepted by the CBI.
}

345 SIC's report, supra note 174 , Volume 1, at 41. 
firms were highly leveraged and so vulnerable to the dramatically reduced liquidity the subprime crisis produced. When the United States government unexpectedly declined to rescue Lehman in September 2008, ${ }^{346}$ international credit markets froze. ${ }^{347}$ When Lehman collapsed on September 15 the Icelandic banks' international sources of funds were drained, and, with the Icelandic government and the CBI financially isolated, the only option left was printing ISK.

This triggered problems everywhere, including for the Icelandic banks - Kaupthing lost its planned sale of its asset finance business to RBS, for example. ${ }^{348}$ Kaupthing Edge, the UKbased internet bank, also began to experience a combination of large numbers of new clients (1500-2000 per day) depositing amounts less than the UK deposit insurance guarantee and an outflow of money from accounts exceeding the maximum, suggesting a loss of confidence in the banking system. ${ }^{349}$ On September 25 , after a German bank had canceled its $€ 150$ million credit line, the chairman of the Glitnir board approached the CBI board of directors for $€ 600$ million of liquidity. ${ }^{350}$ Instead of providing the money, late in the evening of Sunday, September 28 the CBI offered Glitner $€ 600$ million, roughly a fourth of the CBI's currency reserves, in exchange for a $75 \%$ share of Glitnir, leaving Glitnir no time to seek alternative funding and effectively nationalizing the bank. ${ }^{351}$ Glitnir accepted the deal in principle but while it was obtaining the signatures of its major shareholders, CBI chair Davíð Oddsson announced the plan and all three bank stocks fell dramatically. ${ }^{352}$

The nationalization was not well received by financial markets. On October 1, after the CBI's announcement of its takeover, Glitnir's credit ratings were lowered. Since many of Glitner's loans included financial covenants linked to the ratings, international lenders invoked acceleration clauses in the loan facilities. ${ }^{353}$ On October 7, the CBI backed out of the Glitnir takeover, the Parliament passed emergency legislation under which the FSA announced its appointment of a resolution committee to take over the the bank's operations. ${ }^{354}$ Both Kaupthing and Landsbanki suffered serious outflows from their offshore deposit accounts after the announcement of the CBI on September 29. ${ }^{355}$ Landsbanki requested $€ 500$ million on October 6 from the CBI, as the British FSA had demanded the bank make inject $£ 200$ million cash into its

\footnotetext{
${ }^{346}$ William Sterling, Looking Back at Lehman: An Empirical Analysis of the Financial Shock and the Effectiveness of Countermeasures, Oct. 30, 2009 available at http://www.trilogyadvisors.com/worldreport/200910.Lehman.pdf.

${ }^{347}$ See, e.g., Robert Samuelson, Fed Bashing Gone Wild, PostOpinions (Dec. 11, 2011) available at http:/www.washingtonpost.com/opinions/fed-bashing-gone-wild/2011/12/09/gIQA6sMDoO story.html ("After Lehman Brothers' failure in September 2008, American credit markets began shutting down. Banks wouldn't lend to banks. Investors balked at buying commercial paper - a type of short-term loan — and many "securitized" bonds").

348 Thorvaldsson, supra note 43, at 202.

349 Thorvaldsson, supra note 43, at 203.

${ }^{350}$ SIC's report, supra note 174, Volume 1, at 42. Boyes, supra note 4, at 161.

${ }^{351}$ SIC's report, supra note 174, Volume 1, at 42. Boyes, supra note 4, at 162.

352 Boyes, supra note 4, at 162.

${ }^{353}$ SIC's report, supra note 174, Volume 1, at 42. The committee specifies two loans to Glitnir from DZ Bank and Sumimoto Bank amounting to $€ 425$ million and margin calls in total of $€ 1100$ million just over half of which was from the ECB.

${ }^{354}$ SIC's report, supra note 174, Volume 1, at 42-43. Emergency Act, no. 125/2008.

355 SIC's report, supra note 174 , Volume 1, at 44.
} 
UK branch and $£ 53$ million into its UK subsidiary. ${ }^{356}$ The Central Bank turned the request down. ${ }^{357}$ Similarly, on October 3 the British FSA requested Kaupthing to inject $£ 1.6$ million into KSF before October $6 .{ }^{358}$

On October 6 the UK Landsbanki branch was shut down and on October 7, after the passage of the emergency legislation, the Icelandic FSA appointed a resolution committee to take over the operations of Landsbanki. ${ }^{359}$ These events raised important questions about the security of deposits in the now nationalized banks, both inside and outside Iceland. Oddsson went on Icelandic television on October 7 and announced "We do not intend to pay the debts of the banks that have been a little reckless." ${ }^{, 360}$ Earlier that day British Chancellor of the Exchequer Alistair Darling called Icelandic Finance Minister Arni Mathiesen to express concern over British depositors' Icelandic bank deposits. ${ }^{361}$ After some initial confusion because Darling confused Mathiesen, who he had never met, with the Icelandic Minister of Trade, who he had met, the two launched into an exchange that left Darling unsatisfied. ${ }^{362}$ In reaction, Darling told a British television interviewer on October 8 that "The Icelandic government have told me, believe it or not, have told me yesterday that they have no intention of honoring their obligations there."

Also on the morning of October 8 Kaupthing failed to meet the UK FSA's demand to transfer $£ 300$ million into the KSF subsidiary in London, despite a CBI €500 million loan. At 10:00 am October 8 the British Treasury issued the Landsbanki Freezing Order 2008, which included the finding that

The Treasury believe that action to the detriment to the United Kingdom's economy (or part of it) has been or is likely be taken by certain persons who are the government of or resident of a country or territory outside the United Kingdom. The Treasury, in excercise of the powers conferred by sections 4 and 14 of and Schedule 3 to the Antiterrorism, Crime and Security Act 2001(1), make the following order [taking control of the bank]. ${ }^{364}$

The UK FSA then transferred Kaupthing Edge deposits to the Dutch bank ING Direct N.V. It also put the KSF into Moratorium, which in turn led the Icelandic FSA to appoint a resolution committee to take over the operations of Kaupthing on the basis of the emergency legislation. ${ }^{365}$ All three major Icelandic banks were now in government hands.

\footnotetext{
${ }^{356}$ SIC's report, supra note 174 , Volume 1, at 44. The CBI had already lent Kaupthing $€ 500$ million in an attempt to rescue Kaupthing.

${ }^{357}$ SIC's report, supra note 174, Volume 1, at 44. Boyes, supra note 4, at 166.

${ }^{358}$ SIC's report, supra note 174 , Volume 1, at 44

359 SIC's report, supra note 174 , Volume 1, at 44.

${ }^{360}$ Boyes, supra note 4, at 167.

${ }^{361}$ Boyes, supra note 4, at 167.

362 Boyes, supra note 4, at 168-173 (reprinting transcript as leaked by Icelandic authorities).

${ }^{363}$ Boyes, supra note 4, at 173 (quoting Darling).

364 The Landsbanki Freezing Order 2008, No. 2668. The Treasury of the United Kingdom. Also: SIC's report, Volume 6, at 40 .

${ }^{365}$ SIC's report, supra note 174 , Volume 1, at 44.
} 
We will never know whether Kaupthing could have been saved or not. Nor will we know if the U.S. failure to rescue Lehman triggered the problem. It is certain that the U.S. regulatory agencies failed repeatedly during the rise and fall of subprime mortgages and that the policy response in fall 2008 was, at best, ad hoc. Moreover, both the Icelandic and British responses to the crisis make it clear that it is difficult to imagine worse handling of the Icelandic crisis once it began. Whatever the roots of the global crisis or the Icelandic crisis, in neither case did regulators prove adequate to the tasks.

\section{F. Aftermath}

These events left the Icelandic financial system bankrupt, the ISK without credibility and virtually worthless internationally, a debt crisis for many Icelandic households and companies, and a government politically isolated both domestically and internationally. For a few days after the collapse in October 2008 there was real danger of chaos in Iceland as the general public was in a state of shock. ${ }^{366}$ On October 6, Prime Minister Geir H. Haarde delivered a dramatic address to the nation ${ }^{367}$ and the Althingi passed emergency legislation authorizing the FME to takeover the banks and to create new banks, placing the banks' domestic assets and liabilities in the new banks while leaving their foreign assets and liabilities in the estates of the old banks. The Central Bank drew on its currency swap agreements with the Scandinavian banks in mid October.

As discussed earlier, the Act and the events preceding it triggered the UK's use of antiterrorist legislation to freeze the assets of Landsbanki, treating the bank as equivalent to AlQaida and for 24 hours the Icelandic Treasury and the Central Bank of Iceland were on the list as well. ${ }^{368}$ Just as importantly, and as the United States did in the Chrysler and General Motors bailouts, the legislation rearranged the order by which the banks' creditors would recover their money. ${ }^{369}$ It gave domestic deposits priority status, subordinating bondholders and general

\footnotetext{
366 Johannesson gives a good description of the atmosphere in Iceland in October 2008. As currency reserves were scarce and Iceland depends on imports for much of its food supply, Icelanders worried about obtaining necessities. The immediate impact was particularly severe for import businesses and those studying or travelling abroad. Gudni Th. Johannesson, HRUNID: ÍSLAND Á BARMI GJALDTHROTS OG UPPLAUSNAR [THE COLLAPSE: ICELAND ON THE BRINK OF BANKRUPTCY AND CHAOS] at 160, 168-169, 174, 176 and 216-217 (2009).

${ }^{367}$ Address to the Nation by H.E. Geir H. Haarde, Prime Minister of Iceland, October 6, 2008: http://eng.forsaetisraduneyti.is/news-and-articles/nr/3035.

368 Johannesson, HRUNID, supra note 366, at 181.

${ }^{369}$ Between January 1 and September 30, 2008, the ISK had fallen substantially and the Central Bank seemed unable to deal with inflation with interest rates as high as $15.5 \%$. Central Bank of Iceland, Economic Indicators, September 2008. (http://www.sedlabanki.is/lisalib/getfile.aspx?itemid=6451). See also: www.sedlabanki.is, Exchange rate. On September 30 a Euro was quoted at 145.5 in the Central Bank (Exchange rate index at 190.5) from being quoted at 91.2 on December 31, 2007 (Exchange rate index at 120). As the troubles grew the Central Bank's measures became more and more desperate. On October 6 Iceland tried what has been described as the shortest peg in the history of such monetary measures when trying to fix the exchange rate at exchange index rate 175 (meaning that 1 Euro would cost 131 ISK). Johannesson, HRUNID, supra note 366, at 160. The attempt was short-lived. Around noon on October 7 the Icelandic banks quoted one Euro at 158 ISK not the 131 as the Central Bank had hoped, the ECB at 198 ISK and those using Visa credit cards had to pay 228 ISK for the Euro or $75 \%$ more than the fixed rate of the Central Bank of Iceland. Gudni Th. Johannesson, supra, at 169. Johannesson describes on 174 that the Icelandic banks told their clients foreign currency on the Central Bank rate was "sold out." The CBI declared: "For the past two days, the Central Bank of Iceland has carried out foreign currency trading at a different exchange rate than that on the foreign exchange market. It is clear that there is insufficient support for this exchange rate; therefore, the Bank will not make any further such efforts for the time being." www.sedlabanki.is Announcement no. 35/2008.
} 
creditors. ${ }^{370}$ This infuriated the banks' foreign creditors and led to series of lawsuits in the Icelandic courts challenging the legality of the Act. ${ }^{371}$ Under the Emergency Act, the FME proceeded to take control of the banks, starting with Landsbanki and Glitnir on October 7, 2008, appointing Receivership Committees (RC) to take over the operations of the banks and manage their assets. ${ }^{372}$ On October 9, Kaupthing was similarly placed into receivership by the FME. ${ }^{373}$ The RCs later asked the District Court of Reykjavik to appoint Winding-up Boards (WuB) for each bank to handle the claims process within each bank, which the court did. ${ }^{374}$ While the government now holds $81.3 \%$ stake in the new Landsbanki ${ }^{375}$ it holds $13 \%$ in the new Kaupthing (now Arion bank) and 5\% in the new Glitnir (now Islandsbanki), the latter two owned by the creditors under RC management. The arrangement has earned some praise in contrast to the bailouts in other countries. ${ }^{376}$ The Icelandic government has explicitly given full backing to domestic deposits and is the major owner of the new Landsbanki. On October 15 the CBI announcing $3.5 \%$ policy rate reduction in an effort to combat the severe economic consequences of the financial sector's collapse. ${ }^{377}$

Between October 9 and November 5 the ECB quoted a reference rate of 305 ISK to the Euro. European Central Bank, http://www.ecb.int/stats/exchange/eurofxref/html/eurofxref-graph-isk.en.html.

${ }^{370}$ In accordance with the Act of Bankruptcy, art 112.

${ }^{371}$ On October 28, 2011 the Supreme Court of Iceland submitted its ruling in cases 340/2011 (Arrowgrass and others vs. Landsbanki Íslands hf. and The Financial Services Compensation Scheme Limited) and 341/2011 (Arrowgrass and others vs. Landsbanki Íslands hf. and De Nederlandsche Bank N.V.) accepting the priority status of retail deposits on the so-called Icesave accounts in the winding-up process of Landsbanki Íslands hf. The Supreme Court thereby upheld the District Court of Reykjavik's ruling finding the so-called Emergency Act no. 125/2008 to be enacted within the lawful boundaries of the Icelandic constitution no. 33/1944. .

${ }^{372}$ FME Announcement: Decision of the Financial Supervisory Authority on the appointment of a Receivership Committee for Landsbanki Islands hf. (http://www.fme.is/lisalib/getfile.aspx?itemid=5670). FME Announcement: Decision of the Financial Supervisory Authority on the appointment of a Receivership Committee for Glitnir Bank hf. (http://www.fme.is/lisalib/getfile.aspx?itemid=5671). The FME announced that domestic deposits would be fully guaranteed as declared by the government, domestic branches, call centers, cash machines and internet operations would be open for business as usual and that the objective of the FME was to guarantee a functioning domestic banking system. FME news announcements, www.fme.is (http://www.fme.is/?PageID=581\&NewsID=331 and http://www.fme.is/?PageID=581\&NewsID=337).

${ }^{373}$ FME Announcement: Decision of the Financial Supervisory Authority on the appointment of a Resolution Committee for Kaupthing bank hf. (http:/www.fme.is/lisalib/getfile.aspx?itemid=5749), and its news announcement, www.fme.is (http://www.fme.is/?PageID=581\&NewsID=340).

${ }^{374}$ See http://www.kaupthing.com/pages/4216 (on Kaupthings RC), http://glitnirbank.com/the-winding-upboard.html (on Glitnir bank's RC) and http://www.lbi.is/ (on Landsbankinn).

375 See, Icelandic State Financial Investments (ISFI), http://bankasysla.is/en/assets/.

${ }^{376}$ Poul M. Thomsen, How Iceland Recovered from its Near-Death Experience, IMF direct, October 26, 2011, ("First, a team of lawyers was put to work to ensure that losses in the banks were not absorbed by the public sector. In the end, the public sector did of course have to step in and ensure the new banks had adequate capital, but it was insulated from vast private sector losses. This was a major achievement.").

${ }^{377}$ www.sedlabanki.is. Announcement no. 37/2008. (http://www.sedlabanki.is/?PageID=287\&NewsID=1911.) The CBI explained that

The Icelandic economy has been subjected to unprecedented turbulence in the past few weeks. The Icelandic banking system has not been able to withstand the trials it has faced as a result of difficult market conditions, global deterioration of confidence in economic affairs, and domestic risk appetite. A variety of jobs have disappeared virtually in the blink of an eye, demand has 
Bad news continued to arrive during the fall. On October 21 the press reported the details of how smaller banks and financial institutions in Iceland had borrowed large sums from the CBI using bonds issued by the big three banks as collateral. This had enabled the three large banks to use the smaller financial institutions to raise funds. The CBI seemed destined to lose a large portion of these funds; the government stepped in and bailed out the CBI with a 270 billion ISK loan and assumed this collection of troubled assets (book value 345 billion ISK). ${ }^{378}$ Moreover, foreign currency reserves fell rapidly as foreign investors, such as the glacier bond holders, were eager to "escape" the ISK. The government and the CBI introduced capital controls on November 28 to prevent the flow of foreign currency out of the country. ${ }^{379}$

On October 24 the Icelandic government and the IMF announced a "Staff Level Agreement" with the Icelandic government whereby the IMF would lend Iceland US $\$ 2.1$ billion over two years. ${ }^{380}$ Gordon Brown was said to have urged Iceland to turn to the IMF, although many Icelanders believed the British (and the Dutch) were lobbying the IMF board to delay the assistance to pressure Iceland in the Icesave dispute, ${ }^{381}$ discussed below, which increased

declined precipitously, and by all measures, expectations are at a low ebb. The impact of the collapse of the banking system will be extremely burdensome and the accompanying economic contraction very sharp.

Id.

${ }^{378}$ Johannesson, HRUNID, supra note 366, at page 225.

${ }^{379}$ The controls have since been severely tightened, though lawyers have challenged the constitutionality of the rules imposed and the legality of their execution. Capital movements that involve foreign currency are close to being prohibited as a matter of principle while the transfer of ISK between certain foreign and domestic parties are forbidden without a prior acceptance of the Central Bank. Export companies are prohibited from issuing invoices in ISK and obliged, subject to 2 years in prison, to bring to Iceland all foreign currency acquired in their business transactions. Though foreign currency movement in relation to imports and exports of goods and services are largely exempted from the rules, the capital controls are far reaching and have stifled foreign investment. Foreign currency surveillance has been set-up at the Central Bank and people have been under investigation by the police for capital transfers to and from Iceland and even within Iceland. The government has empowered the Central Bank to survey individual credit card bills in search for "irregular" currency movements. Foreign currency is rationed to individuals and travelers need to show their airline tickets to be able to purchase foreign currency for their vacations. Rules no. 1082 of November 28, 2008 on Foreign Exchange, based on a Temporary Provision of the Foreign Exchange Act No. 87/1992. http://www.sedlabanki.is/lisalib/getfile.aspx?itemid=6631.

${ }^{380}$ IMF press release No. 08/256, http://www.imf.org/external/np/sec/pr/2008/pr08256.htm.

${ }^{381}$ On November 16 Iceland agreed to guidelines to form the basis for the negotiations, which were the result of talks between the Icelandic government and "several EU member states initiated by French EU Presidency", making quite clear the relationship between the Icesave affair and the IMF program. Iceland Prime Ministers Office's News Article, November 16, 2008. http://eng.forsaetisraduneyti.is/news-and-articles/nr/3229. The Guidelines read as follows: "1.The Government of Iceland has held consultations with the EU Institutions and the Member States concerned regarding the obligations of Iceland under the EEA with respect to the Deposit Guarantee Directive 94/19/EC. All parties concluded that the Deposit Guarantee Directive has been incorporated in the EEA legislation in accordance with the EEA Agreement, and is therefore applicable in Iceland in the same way as it is applicable in the EU Member States. 2. The acceptance by all parties of this legal situation will allow for the expeditious finalization of negotiations underway concerning financial assistance for Iceland, including the IMF. These negotiations shall be conducted in a coordinated and consistent way, and shall take into account the unprecedented difficult situation of Iceland and therefore the necessity of finding arrangements that allow Iceland to restore its financial system and its economy. 3. The EU and the EEA Institutions will continue to be involved and consulted on this process." 
opposition towards the IMF assistance among the general public. ${ }^{382}$ There was also talk of a Russian loan. ${ }^{383}$

The financial collapse created political turmoil in Iceland, as angry voters demanded explanations, resignations and accountability. In early December the Althingi passed an act creating a new Office of Special Prosecutor charged with criminal investigation of actions related to the financial collapse. ${ }^{384}$ Also in December 2008 Althingi appointed a Special Investigation Commission charged with "seeking the truth" about the causes of the banks" collapse, to assess whether mistakes were made in the execution or the surveillance of rules and regulation on financial markets in Iceland, and to determine if government bodies or officials neglected their duties. ${ }^{385}$ As the population took to the street demanding action, the government faltered. In January 2009 the coalition government of the Independence Party and the Social

\footnotetext{
382 Johannesson, HRUNID, supra note 366, at 242-243. Johannesson notes that in an interviews on November 6, 2008 Prime Minister Geir H. Haarde said he could not believe that the IMF would be abused to oppress Icelanders. He also tells of an outburst of the President of Iceland, Ólafur Ragnar Grimsson, in a lunch meeting at the Danish embassy in Iceland, where he supposedly reprimanded ambassadors and officials from neighbour countries, that Denmark, Sweden and other friendly countries had failed Iceland at a time of need. Johannesson furthermore discusses the evidence on the pressure within the IMF. Johannesson, HRUNID, supra note 366, at 248-49.

383 Johannesson, HRUNID, supra note 366, at 112, 231. As the European governments seemed fixed on the idea that Icelandic taxpayers needed to bailout the failed banks and it seemed as the IMF was being pressured to that effect, a possible emergency loan from Russia may have complicated things. On October 7 David Oddsson announced a possible 4 billion EUR loan from Russia, which might have rendered the IMF loan unnecessary. Johannesson, supra, at 159. Many thought the announcement was premature, and in the early days of October a sign of despair. In the context of international politics people still have entertained the idea that this was a "Russian Card" played by the Icelandic government to remind its fellow NATO members of the Russian interest in the North Atlantic and the strategic importance of Iceland. Johannesson, supra, at 166-168. This has been dismissed by Icelandic politicians, who assert the Russian loan was a desperate measure taken to secure the funds Iceland so desperately needed. Johannesson, supra, at 167-168. However Johannesson asserts that Jaap De Hoop Scheffer, Secretary General of NATO, was generally concerned of the Russian Loan and that José Manuel Barrosso, President of the European Commission raised similar concerns in his talks with Prime Minister Haarde. Johannesson, supra, at 223-224. Johannesson discusses that Haarde had told De Hoop Scheffer that the Icelandic public would resent the idea that the UK would cover NATO's air surveillance over the Icelandic air-zone as they were supposed to at the end of 2008. Also that Thorsteinn Ingolfsson, Permanent Secretary of Iceland to NATO had in Brussels at NATO Eurpoean headquarters strongly objected to the UK's use of anti-terrorist legislation against a fellow NATO country and put it on a list of terrorists. On November 19 the Executive Board of the IMF approved a two-year US\$2.1 billion "StandBy Arrangement for Iceland to support the country's program to restore confidence and stabilize the economy" (IMF Press Release no. 08/296, November 19, 2008. http://www.imf.org/external/np/sec/pr/2008/pr08296.htm)
}

${ }^{384}$ Act no. 135/2008, on the Office of the Special Prosecutor. According to Article 1: "The office of the Special Prosecutor shall investigate suspicions of criminal actions connected with the operations of financial undertakings and by those who have held shares in those undertakings or have exercised voting rights in them, and similarly suspicions of criminal actions on the part of the managers, advisors and employees of financial undertakings and other persons who have been involved in the activities of the undertakings. As appropriate, the office shall follow up these investigations by instituting criminal proceedings.“ The Act was amended with Acts no. 25/2009, no. 80/2009 and 52/2010. http://eng.innanrikisraduneyti.is/laws-and-regulations/english/procedural-law/nr/6608. Hundreds of bankers have been questioned by the SPO, many of which have received the status of suspects, resulting in their job loss. Only a handful have yet been charged with a felony and none sentenced by the Icelandic Courts.

${ }^{385}$ Act no. 142/2008 on the Investigation of the Preceding Events and Causes that led to the fall of the Icelandic Banks in 2008 and related Events. The members of the SIC were Dr. Páll Hreinsson, Judge at the Supreme Court, Tryggvi Gunnarsson, Parliamentary Ombudsman of Iceland, and Sigríður Benediktsdóttir Ph.D. lecturer and associate chair at Yale University. 
Democratic Alliance resigned following riots in downtown Reykjavik. ${ }^{386}$ A temporary, minority government of the Social Democratic Alliance and the Left Green Party took charge, with the neutral support of the Progressive Party. ${ }^{387}$ In the general elections in June 2009 support for the Independence Party, strongly associated with the rise and fall of the Icelandic economy, fell to historic lows. ${ }^{388}$ For the first time since independence, the left wing parties (the Left Green Party and the Social Democratic Alliance) won majority in the Althingi, forming a majority government. $^{389}$

One of the major political and economic challenges for the government was to deal with the problems caused by the Icelandic banks' internet accounts. Both the Dutch and the UK governments had bailed out the depositors in Landsbanki's Icesave subsidiaries, which had been created as branches of Landsbanki in both countries. The Dutch and British then argued that under the EEA Agreement Iceland had an obligation to pay them back for the compensation they had provided Landsbanki depositors. ${ }^{390}$ The Icelandic government rejected these claims, arguing that it was obliged only to compensate depositors to the limits of the guarantee fund. ${ }^{391}$ In Defence of Iceland, a citizens group created in October 2008, sent the UK Parliament a 75,000 signature petition in March 2009 declaring "Icelanders are NOT terrorists", reacting to the UK's use of anti-terror legislation to seize Icelandic assets in the UK. ${ }^{392}$ After some tumultous initial negotiations between the old coalition government in Iceland and several European governments, ${ }^{393}$ the minority government appointed a new negotiating committee spearheaded by former socialist leader Svavar Gestsson in early $2009 .{ }^{394}$

\footnotetext{
${ }^{386}$ Prime Minister Office's online publication: Prime Minister Formally Tenders Government's Resignation, http://eng.forsaetisraduneyti.is/news-and-articles/nr/3348 (In his statement Prime Minister Geir H. Haarde said: "Unfortunately, what I have feared might happen ever since the collapse of the banks at the beginning of October, has now happened, with a political crisis now added to the economic crisis. I urge all members of parliament now to rise to the occasion and the responsibility entrusted to them by the nation, to make sure that the wide-reaching rescue actions currently underway are not wiped out by anarchy and chaos.")

${ }^{387}$ Prime Minister Office's online publication: New Icelandic Government formed http://eng.forsaetisraduneyti.is/news-and-articles/nr/3369

${ }^{388}$ Statistics Iceland, available at: http://www.statice.is/Statistics/Elections/General-elections

${ }^{389}$ Statistics Iceland, available at: http://www.statice.is/Statistics/Elections/General-elections. Prime Minister Office's online publication, New Government Takes Office - Social Democrats and Left Greens Continue their Coalition Partnership: http://eng.forsaetisraduneyti.is/news-and-articles/nr/3699

390 See M. Elvira Mendez-Pinedo, Icesave-Iceland (Feb 2010) available at http://elvira.blog.is/blog/elvira/entry/1013839/ (summarizing legal arguments).

${ }^{391}$ supra note 33, http://thjodaratkvaedi.is/2011/en/theicesavedispute.html. Specifically, Iceland argued that "the EU rules on deposit guarantees, which have been incorporated into Icelandic law, do not impose a legal obligation on states to guarantee the deposits of customers of the banks over and above the assets of the guarantee fund in any given case. Thus, it argues, Member States cannot bear liability towards the banks' customers if the states have established deposit guarantee schemes." Introductory website directed by the Law Institute of the University of Iceland set up before the national Referendum on April 9, 2011. http://www.thjodaratkvaedi.is/2011/en.html.

$392 \mathrm{http}: / /$ indefence.is/?m=0

${ }^{393}$ On November 4, 2008 the Finance Ministers of the EU and the EFTA met at a regular meeting in Brussels, chaired by the French Minister Christine Lagarde. Johannesson, HRUNID, supra note 366, at 241. Johannesson claims that under pressure and outnumbered by his colleagues Arni M. Mathiesen the Icelandic minister of finance gave in and agreed upon an Arbitrary Court ruling, consisting of five members appointed by EU Council of Ministers, the EU Commission, the ECB, the EFTA Surveillance Authority and the Icelandic Government. Id.
} 
Gestsson reached an agreement in June 2009 with the Dutch and UK governments, accepting repayment obligations of nearly $€ 4$ billion over a period of 15 years at $5.55 \%$ interest and "with termination clauses [...] restrictive waivers of defence and sovereign immunity, and waivers of the right for legal appeal against the governments." 395 The terms provoked widespread anger in Iceland, ${ }^{396}$ as the government plan of funding the restoration of the banking sector and bailing out Icelandic depositors in full, on top of IMF and other foreign debt assumed in the efforts to restore the ISK, laid a heavy burden on Icelandic taxpayers. One calculation put the amount of debt per Icelandic citizen at $\$ 403,000 .{ }^{397}$ Although the Althingi passed implementing legislation on August 28, it did so with important and extensive preconditions. ${ }^{398}$ Icelandic President Olafur Ragnar Grimsson ${ }^{399}$ relied on those preconditions in signing the legislation. ${ }^{400}$ After pressure from the UK and Netherlands, the Althingi narrowly passed a new act by a margin of 33-30, removing the preconditions in December. ${ }^{401}$ This time Pres. Grimsson rejected the bill, only the second time in Iceland's history that a president had refused to assent to legislation passed by the Althingi. ${ }^{402} \mathrm{He}$ did so in response to a petition signed by a quarter of the electorate, calling for a national referendum on the issue, to opinion polls, and to requests from members of the Althingi. ${ }^{403}$ The referendum was held on March 6, 2010 and $98.1 \%$ voted no (with participation at $62.7 \%$ of the electorate.) ${ }^{404}$ Somewhat bizarrely, Prime Minister Johanna

Iceland obviously being at a disadvantage the Icelandic government resigned from the agreement on the arbitration. Id. at 242 .

${ }^{394}$ Though people advocated the use of international specialists in the negotiation process, the government went with their own despite criticism of their lack of experience in such dealings.

${ }^{395} \mathrm{http}: / /$ indefence.is/?m=2.11. See the UK Agreement: http://www.island.is/media/frettir/01.pdf. The Dutch Agreement: http://www.island.is/media/frettir/02.pdf.

${ }^{396} \mathrm{http}: / /$ indefence.is $/ ? \mathrm{~m}=0$

${ }^{397}$ Boyes, supra note 4, at 144.

398 Act no. 96/2009, Parliamentary document no. 358, Parliamentary session 137, case no. 136:http:/www.althingi.is//dba-bin/ferill.pl?ltg=137\&mnr=136. The most important preconditions were: 1 . The Agreements were interpreted according to the Guidelines agreed upon in November 2008, 2. Certain sovereign rights of Iceland would be respected, i.a. on the inalienable sovereign right to natural resources within the EEZ of Iceland. 3. Economic principles, i.a. that payments would not exceed certain limit of GDP so that the Agreements would not be overburdening. 4. Legal principles, i.a. the effect of a court ruling in Iceland's favor in a legal dispute on the state guarantee and on the priority status of claims in the winding-up process of the estate of Landsbanki.

${ }^{399}$ Grimsson began his career on the left of Icelandic politics, although some saw him as transformed into "the spokesperson for the corporation and the banks" after he became president. Boyes, supra note 4, at 107 (quoting journalist Sveinn Birkir Bjoernsson).

${ }^{400}$ Statement by the President of Iceland, 2 September, 2009, regarding the Act No. 96/2009: http://english.forseti.is/media/PDF/09_09_02_statement_w_sign.pdf.

${ }^{401}$ Act no. 1/2010, Parliamentary document 626, Parliamentary session 138, case no. 76: http://www.althingi.is/dbabin/ferill.pl?ltg=138\&mnr=76.

402 The first time was also a bill rejected by Grimsson.

${ }^{403}$ Declaration by the President of Iceland, January 5, 2010.

${ }^{404}$ Statistics Iceland: http://www.statice.is/pages/2465 
Sigurdardottir did not vote and called the referendum meaningless as Iceland, Britain and the Netherlands had already reopened negotiations. ${ }^{405}$

Iceland's negotiators in the second round were headed by Lee C. Buchheit of Cleary, Gottlieb, Steen and Hamilton rather than an Icelandic politician. ${ }^{406}$ On December 8, 2010, negotiators for Iceland, the UK, and the Netherlands announced a new agreement. ${ }^{407}$ These second agreements were widely regarded as significantly less burdensome, primarily because they used a 3.2\% interest rate (instead 5.55\%) but also because of other changes. ${ }^{408}$ Icelandic public opinion initially favored them and legislation authorizing them passed in Althingi on February 16, 2011 by a margin of 44-16. ${ }^{409}$ However, as the details became clear, opposition grew as public opinion solidified behind the idea that the taxpayers should not assume the obligations of the failed banks. Once again Pres. Grimsson refused to sign the bill, sending it to a referendum. ${ }^{410}$ This time the bill was rejected by $59.7 \%$ (with $75.3 \%$ participation). ${ }^{411}$ As a result, the Icelandic government is now preparing to defend its legal interpretation of the deposit insurance obligations in an proceeding brought by the EFTA Surveillance Authority in the EFTA Court. $^{412}$ This process is ongoing.

\footnotetext{
${ }^{405}$ Iceland holds referendum on Icesave repayment plan, BBC News, March 6, 2009: http://news.bbc.co.uk/2/hi/business/8552971.stm

${ }^{406}$ Buchheit to Lead Iceland's Icesave Talks. Iceland Review, February 10, 2010: http://icelandreview.com/icelandreview/daily_news/?ew_0_a_id=357656

${ }^{407}$ Summary of the Negotiating Committee on the Outcome of Discussions with the UK and Dutch Governments concerning Icesave, December 9, 2010:

http://eng.fjarmalaraduneyti.is/media/Summary_of the_Negotiating_Committee_concerning_Icesave.pdf. The Agreements see supra note 33: http:/www.thjodaratkvaedi.is/2011/en/component/content/article/120.html.

${ }^{408}$ Comments on Icesave, case no. 388, Parliamentary document 546, GAM Management hf., January 10, 2011, page 60-61, and Comments on the new Icesave Agreement IFS Greining, January 11, 2011, page 2.

${ }^{409}$ Act No. 13/2011, Parliamentary document 856, Parliamentary session 139, case no. 388: http://www.althingi.is/dba-bin/ferill.pl?ltg=139\&mnr=388.

${ }^{410}$ Declaration by the President of Iceland, Ólafur Ragnar Grímsson, February 20, 2011 : http://english.forseti.is/media/PDF/2011_02_20_icesave3_eng.pdf.

${ }^{411}$ Advertisement on the results of the Referendum on the validity of the Act no. 13/2011, April 15, 2011: http://www.kosning.is/thjodaratkvaedagreidslur2011/frettir/nr/7870.

412 The Icelandic government issued a statement on April 10:
}

On 26 May 2010, the EFTA Surveillance Authority ( ESA), initiated infringement proceedings against Iceland, claiming that Iceland is under an obligation under Directive 94/19 on deposit guarantee schemes to ensure that each depositor does receive the payment foreseen by the Directive in terms of a guarantee for the deposit by issuing a letter of formal notice to the Government. The process had not advanced much, as the outcome of the negotiations and later the referendum were awaited, as a positive vote would have made the legal issue immaterial. Following the no vote of the referendum, the Government will proceed to submit its observations, in line with the strong will of the people of Iceland expressed in the vote. ESA can ultimately bring the matter before the EFTA Court. The average duration of court proceedings before the the EFTA Court is one year. The Icelandic Government has sought to resolve the Icesave dispute all along in good faith and through negotiations with the British and the Dutch Governments. The outcome of the referendum can however only be interpreted to the effect that the Icelandic people will not accept a deal requiring Iceland to cover costs related to the Icesave deposit insurance guarantees, unless the legal obligation for doing so is clear .... 
The Special Investigation Commission of Althingi (SIC) delivered its much awaited, more than two thousand page report on April 12, 2010. It concluded that former Prime Minister Haarde, former Finance Minister Mathiesen, and former Minister of Business Affairs Björgvin G. Sigurðsson "showed negligence, within the meaning of Article 1(1) of Act No 142/2008, during the time leading up to the collapse of the Icelandic banks, by omitting to respond in an appropriate fashion to the impending danger for the Icelandic economy that was caused by the deteriorating situation of the banks." ${ }^{413}$ It also concluded that "Mr. Jónas Fr. Jónsson, then Director General of the FME, and Mr. Davíð Oddsson, Mr. Eiríkur Guðnason and Mr. Ingimundur Frioriksson, then Governors of the CBI, showed negligence, within the meaning of Article 1(1) of Act No 142/2008, in the course of particular work during the administration of laws and rules on financial activities, and monitoring thereof." 414 The Althingi created a Parliamentary Review Committee on the SIC report, which it granted the authority to take a position on ministerial responsibility for conduct in the run-up to the crisis based on the SIC report. On September 11, 2010, the majority of the PRC proposed to Althingi that Haarde, Mathiesen, Sigurðsson and Ingibjörg Sólrún Gísladóttir, the former chairman of Social Democratic Alliance and Minister of Foreign Affairs, be prosecuted on grounds of negligent behavior in 2008, before the Landsdómur (National Court), a body which had never before been summoned in the history of the republic. ${ }^{415}$ On December 28, Althingi voted 33-30 to prosecute only former Prime Minister Haarde, and these ongoing proceedings continue to be controversial. $^{416}$

The IMF has praised the Icelandic government's economic recovery efforts and has continued to financially support its efforts. ${ }^{417}$ Between 2008 and 2010 Iceland seemed to be adjusting quickly and there were signs of a gradual recovery of the economy. ${ }^{418}$ In a June 2011 report, the IMF concluded that a post-crisis recovery was underway, but fragile and pointed out that in the last quarter of 2010 the economy stopped contracting on a year-on-year basis for the first time since the crisis. ${ }^{419}$ It also noted that the exchange rate (with foreign exchange still

signalled that now there is finally a consensus in Iceland to defend the government's legal position at a court level.

Statement from the Government of Iceland on the outcome of the referendum on the Icesave Agreements, press releas no. 3/2011, April 10, 2011: http://www.ministryoffinance.is/publications/news/nr/14151.

${ }^{413}$ SIC's report, Chapter 2, Executive Summary in English, page 18. http://sic.althingi.is/pdf/RNAvefKafli2Enska.pdf

${ }^{414}$ SIC's report, Chapter 2, Executive Summary in English, page 18. http://sic.althingi.is/pdf/RNAvefKafli2Enska.pdf. See also more material in English on the SIC Report at: http://sic.althingi.is/

${ }^{415}$ A Parliamentary Resolution Proposal on the Prosecution of Ministers, Parliamentary document no. 1502, Parliamentary session 138, case 706 . . Info on the PRC:

http://www.althingi.is/vefur/parliamentary_review_committee.html

${ }^{416}$ A Parliamentary Resolution on the Prosecution of Ministers, Parliamentary document 1538, Parliamentary session 138, case 706: http://www.althingi.is/dba-bin/ferill.pl?ltg=138\&mnr=706

${ }^{417}$ Statement by an IMF Mission to Iceland, Press Release No.11/269, July 1, 2011.

${ }^{418}$ Iceland's economic situation in Autumn 2010, Confederation of Icelandic Employers (SA) (http://www.sa.is/files/icelands economic situation in autumn 2010 327714346.pdf). Revised Economic Forecast 2011-2013, Icelandic Confederation of Labour (ASÍ), March 2011.

${ }^{419}$ IMF Country Report No. 11/125, June 2011: http://www.imf.org/external/pubs/ft/scr/2011/cr11125.pdf 
subject to capital controls) and financial and capital markets had remained broadly stable (with the caveat that activity outside public and publicly guaranteed bonds has been limited), and that external net debt had fallen to an estimated $170 \%$ of GDP. ${ }^{420}$ The effects of the crisis lingered, however. Unemployment, which rose from under 2\% in September 2008 to $10 \%$ by the spring of 2009, has remained between 7-9\% during 2009-2011, while net migration of foreign workers has turned negative and Icelanders have been emigrating in search of work. ${ }^{421}$ Inflation did drop below the Central Bank's target under the capital controls regime but there are indicators it is creeping back based on commodity price rises, wage increases and a weakening of the ISK despite the controls. ${ }^{422}$ Sovereign CDS spreads remain stable and are lower than those of Ireland, Portugal, Spain or Greece, although that is a low bar. ${ }^{423}$ Housing prices have stopped falling, but given the stringent capital controls the housing market benefits for the lack of alternative investment opportunities, and the public Housing Fund is in serious need of capital. ${ }^{424}$ The IMF report noted that credit levels remain flat despite historic low interest rates (around 5\%). ${ }^{425}$ This reflects the indebted private sector in Iceland, both corporate and household, and their limited access to capital at the new banks. Economic growth is predicted to be at $2.5 \%$, driven by investment in the energy sector, ${ }^{426}$ but many remain skeptical as the left wing government has delayed the approvals on ideological grounds. The government's reversal of many pre-crash policies is drawing criticism within Iceland. ${ }^{427}$ In particular, the 33-29 vote in the Althingi to

${ }^{420}$ IMF Country Report, supra note 419. The difference between those Icelanders migrating outward and inward was around 2500 people in 2009 and 1500 people in 2010.

${ }^{421}$ IMF Country Report, supra note 419.

${ }^{422}$ IMF Country Report, supra note 419.

${ }^{423}$ IMF Country Report, supra note 419. See also Andrew Ward, Iceland prepares \$1bn bond issue, FINANCIAL TIMES, June 8, 2011: http://www.ft.com/cms/s/0/264b7972-91fc-11e0-b8c1-00144feab49a.html\#axzz1RPbilfOg

${ }^{424}$ IMF Country Report, supra note 419.

${ }^{425}$ IMF Country Report, supra note 419.

${ }^{426}$ IMF Country Report, supra note 419.

${ }^{427}$ Confederation of Icelandic Employers' news release, June 24, 2011: http://www.sa.is/frettir/almennar/nr/5243/. The Icelandic Chamber of Commerce has pointed out that "Iceland drops the most of all countries on the Wall Street Journal's ranking of countries by their economic freedom. The reasons are a large budget deficit, increased size of the general government, macroeconomic instability, tax rises and currency restrictions." The Icelandic Economic Situation, Status Report, Iceland Chamber of Commerce, April 2011, page 27. The Confederation of Icelandic Employers has maintained that a 4-5\% economic growth is necessary for a sustainable economy and that the government policies fall short of creating the right environment. Confederation of Icelandic Employers' news release June 21, 2011: http://www.sa.is/frettir/almennar/nr/5240/. In addition, the government has instigated wide range of tax hikes despite the economic downturn. Skattkerfi atvinnulífsins (e. The Economy's Tax System.), Confederation of Icelandic Employers and Iceland Chamber of Commerce, September 2010, http://www.vi.is/files/2010.09.21-Skattkerfi-atvinnulifsins 96890470.pdf. Also criticized is the government's plan to dramatically change the internationally praised ITQ system in fisheries, with the OECD recently urging the government to preserve the system. Economic Survey of Iceland 2011, OECD:

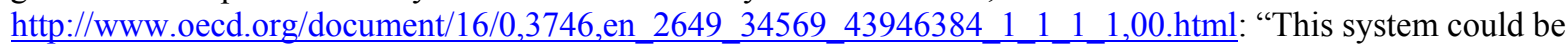
threatened by potential policy responses to the perceived unfairness of quotas initially having been given away and Iceland's possible accession to the EU. It should be kept in mind that when the quotas were initially allocated the right to fish was limited, as this was a move from an open access system. However, there is nothing the government can do now to undo the perceived unfairness of the initial allocation as most current quota holders purchased their quotas. Nevertheless, to strengthen political consensus on the quota system, the government should increase the special resource tax on fishing to a level that neither causes financial difficulties in the industry nor destroys the 
apply for a membership of the EU on July 16, 2009 despite a strong majority of Icelanders being opposed to EU-membership according to polls is causing unrest. ${ }^{428}$ Negotiations started on June 27, but it is widely believed in Iceland and even within the EU-structure, that the majority of the people and of the Althingi will vote against any agreement and that seeking EU membership is a mistake at this point in time. ${ }^{429}$

\section{Lessons}

Iceland's financial crisis has lessons for other small economies, for larger economies, and for financial regulation generally. Most of the post-crisis writing on Iceland's experience concludes that the story points to the need for new regulators, for better regulators, and/or for more regulation. For example, Boyes termed the 2001 Stiglitz report to the Central Bank of Iceland "an appeal for intelligent regulation to shield a tiny economy in any forthcoming crisis." ${ }^{430}$ Of course, it would be wonderful if it were possible to draft a rule, hire a regulator, or design an agency that would prevent the "next Iceland." Given the structure of the problems we've identified, however, we do not think it is possible to do so. These "we just need better or more [fill in the blank]" analyses of the Icelandic crisis miss the central lesson: The problem is not that there were laws broken, badly written, or poorly enforced. As we described above, there were plenty of all three of those kinds of errors made in Iceland both during the boom and during the crisis. But there are always going to be laws broken, badly written, and poorly enforced. A robust financial system cannot be premised on perfect compliance, defect-free-legislation, or omniscient regulators with perfect judgment. The inevitability of the failure of imperfect human institutions must be a consideration in the design of those institutions; the system needs to be robust enough to survive multiple failures.

The central issue missed by the calls for more and better regulation by more and better regulators and bigger and more powerful agencies is the absence of feedback within the regulatory environment as currently structured. We live in a world of open economies with free movement of capital, and the features of that world that provide enormous benefits are also the features that make it dangerous. If we want to keep the benefits, we need feedback from markets to regulators and back, among market participants, and among regulators that will push both market actors and regulators to self-correct when they make a mistake, when an institution proves flawed, or when someone breaks a law. Some of the post-crisis reforms proposed, such as calls for bans on short selling or more stringent deposit insurance terms, dampen rather than amplify, such feedback. Moreover, the absence of institutional constraints on monetary and fiscal

quota system. The government should also progressively reduce TACs from the level compatible with biological sustainability to the level that maximises resource rents where needed and tax away all of this increase in rent. To maintain the value of the fisheries resource within the EU, the Iceland authorities plan to negotiate to maintain the power to set TACs on a scientific basis and to preserve the ITQ system."

${ }^{428}$ Confederation of Icelandic Employers, supra note 418. See Iceland's application, http://www.eeas.europa.eu/iceland/iceland_application.pdf.

${ }^{429}$ Successful start of Iceland's membership negotiations with the EU, European Commission Press Release, June 27, 2011:

http://europa.eu/rapid/pressReleasesAction.do?reference $=\mathrm{IP} / 11 / 791 \&$ format $=$ HTML\&aged=0\&language $=\mathrm{EN} \& \mathrm{guiL}$ anguage $=$ en. See also: EU Commission doubts Iceland will approve membership in referendum, Pressan, May 20, 2010: http://www.pressan.is/News/ReadIcelandicNews/eu-commission-doubts-iceland-will-approve-membershipin-referendum.

${ }^{430}$ Boyes, supra note 4 , at 152. 
authorities' behavior equivalent to those that earlier international monetary systems imposed ${ }^{431}$ means that mistakes by large economies' central banks are both more likely to occur and to have more systemic effects when they inevitably occur. As external constraints on monetary and fiscal authorities loosen, making sure there are robust feedback loops becomes ever more critical.

Our analysis suggests that the key lessons of the Icelandic financial crisis are:

- Monetary and fiscal policies play critical roles in the operation of financial regulation, roles which have largely been ignored by lawyers and regulators. Financial institutions do not exist in a vacuum and discussing their regulation as if they did leads to serious errors. Regulators need to invest more heavily in understanding how changes in monetary and fiscal policies affect financial institutions and markets. Even with greater understanding, however, these impacts should cause financial regulators to approach their task with greater humility, since the impacts are often difficult to predict in advance or even observe.

- There is a need to move beyond the regulation/deregulation dichotomy in discussions of financial institutions. The Icelandic crisis, like the broader global financial crisis, was caused by the interaction of a complex set of regulatory failures, market conditions, and market actions. Some of the problems were the result of changes in Icelandic regulations, some were the result of changes in European Union or British regulations, and some came about because of changes in the global economy. Understanding how to cope with a vastly complex set of policies, economic conditions, and actions by market participants requires looking beyond the labels "deregulation" or "regulation".

- Existing regulatory structures for financial surveillance are deeply flawed by their inability to keep pace with financial innovation. No regulator caught the Icelandic crisis in advance (or the Irish, Greek, Portuguese or Spanish ones now roiling financial markets). Rather than attempting to keep up with financial markets by expanding the scope of regulation, regulators need focus their efforts structurally on ensuring that financial innovations are exposed to market discipline, harnessing the profit motive to burst asset bubbles sooner, reveal problems faster, and undercut fraudulent behavior more swiftly.

- Existing jurisdictionally-based regulatory approaches to issues such as deposit insurance are not only inadequate to handle the problems posed by global financial institutions but make matters worse by insulating market actors from market forces. These inadequacies require rethinking financial regulation rather than simply scaling them up to cover ever-wider areas, as the failure of the EU's deposit insurance regulation to address conditions that allowed the Icesave problem to occur demonstrates.

\footnotetext{
${ }^{431}$ Both the gold standard prior to World War I and the convertibility of the dollar to gold after World War II through the end of the Bretton Woods agreement provided such constraints. Michael D. Bordo \& Finn E. Kydland, The gold standard as a rule, in THE GOLD STANDARD IN THEORY AND HISTORY 85 (Barry J. Eichengreen \& Marc Flandreau, eds. 1985) (describing success of gold standard as a commitment device); Michael D. Bordo \& Anna Schwartz, The Operation of the Specie Standard-Evidence for Core and Peripheral Countries, 1880-1990, in Currency Convertibility: The Gold StAndard And Beyond (Jorge Braga de Macedo, et al., eds. 1996) 51 (convertibility as constraint).
} 
- Despite their roots in finance, financial crises have significant political components. No international regulatory institutions can override national political interests, as both Icelandic politicians' behavior in the lead up to the crisis and Britain's behavior in the Icesave affair demonstrate. Not only do the political uncertainties provide another reason for regulatory humility, they also illustrate a key advantage of market checks and balances over regulatory ones. As the assorted crisis-of-the-week CDS spread and bond market events involving Greece, Ireland, Portugal and Spain have repeatedly demonstrated, market forces play an important role in testing the soundness of politically-crafted solutions.

These conclusions do not point toward a single "solution" to the problems posed by the Icelandic crisis, the on-going European crises, and the larger global financial crisis but rather caution against assuming that any regulatory framework can be sufficient. They also point toward important design principles for regulation, focusing attention on enhancing opportunities for market discipline rather than relying primarily on oversight by regulators. If the financial community, politicians, and regulators learn these lessons, we may avoid the "next Iceland" by avoiding reliance on a regulatory structure that cannot support us when the financial weather next turns foul.

\section{A. Monetary and Fiscal Policy Links to Financial Regulation}

Some argue that the Icelandic crisis was "above all a failure of central banks," whose adherence to inflation targeting meant the central banks missed asset bubbles. ${ }^{432}$ More broadly, the U.S. Federal Reserve and its former chair, Alan Greenspan, have come under heavy criticism for their failure to head off the asset bubbles in the United States. ${ }^{433}$ In addition, not only did European institutions including (but certainly not limited to) Eurostat and the ECB fail to prevent the problems in Greece, Ireland, Spain, and Portugal which were well within the scope of their pre-crisis regulatory responsibilities, but the ECB contributed to the global problem of easy money that played such an important role in Iceland's problems as well as in the larger financial crisis. ${ }^{434}$ Similarly, the Bank of England and the U.K. F.S.A. both failed to prevent the Icesave debacle in Britain, arguably made the problem much worse through the Bank of England's actions with respect to the Kaupthing Singer Friedlander Isle of Man subsidiary, ${ }^{435}$ and definitely

\footnotetext{
${ }^{432}$ Boyes, supra note 4, at 124.

${ }^{433}$ See, e.g., William Fleckenstein \& Frederick Sheehan, Greenspan's Bubbles: The Age of Ignorance at the Federal Reserve (2008). Greenspan admitted the Fed failed to foresee the bubble. Alan Greenspan, The Crisis (March 9, 2010).

${ }^{434}$ See Angela Maddaloni \& Jose-Luis Peydro, Bank Risk-Taking, Securitization, Supervision and Low Interest Rates: Evidence from the Euro Area and the U.S. Lending Standards, ECB Working Paper Series No. 1248 (Oct. 2010) available at http://www.ecb.europa.eu/pub/pdf/scpwps/ecbwp1248.pdf.

435 See Governments petitioned on savings, BBC News (20 Oct. 2008) available at http://news.bbc.co.uk/2/hi/europe/isle of man/7679441.stm. The Isle of Man government's official inquiry concluded that the collapse of the IOM Kaupthing entity was at least partly brought about by the UK FSA's decision not to consult with either the directors of the IOM entity or IOM financial regulators: "The regulators in London stopped talking to those in the Isle of Man in a frank way. Those who might be thought to have a right to know about the circumstances of the London entity, including the directors in the Isle of Man and the FSC, were cut out of the information loop." Tynwald, First (InTERIM) Report Of The SELECT COMmitTeE On Kaupthing, Singer And FRIEDLANDER (ISLE OF MAN) LIMITED 41 (2009) available at http://www.tynwald.org.im/. Further, the IOM inquiry concluded that "The death blow to KSF in London and in the Isle of Man was delivered by the actions of the UK
} 
made the problems worse in Iceland through Britain's obstruction of international recovery efforts as a negotiating tactic. ${ }^{436}$ We agree with many of these criticisms, but they do not address the crucial issue of the impact of monetary policy (either alone or in conjunction with fiscal policy) on financial regulation. It is not simply bad performance by any particular regulator, but that without the larger context of monetary policy, expansionary fiscal policies, and open capital markets, it is impossible to understand the Icelandic (or Greek, Irish, Spanish, or Portuguese) portions of the larger crisis. As others have described in considerable detail, it is similarly impossible to understand the U.S. portion of the crisis. ${ }^{437}$

As we discussed in Part II, monetary and fiscal policy mistakes played crucial roles in the Icelandic crisis in at least two ways. First, outside of Iceland, the U.S., British, E.U. and Japanese central banks aggressively pursued loose money policies that flooded the world's economies with cheap cash. They did this at the same time as their governments were aggressively pursuing fiscal stimulus policies that pumped money into the world economy. Both fiscal and monetary policies thus contributed to widespread liquidity and low returns on deposits in the major financial markets. In particular, the fiscal policies of the American, Japanese, and European governments during the late 1990s and early 2000s created such pressures on their currencies relative to the ISK because the Icelandic government was flush with cash during this period and so appeared a model of relative fiscal probity, despite its own rapidly growing public expenditures. ${ }^{438}$ The combination of the Icelandic government's aggressive fiscal policy and the Icelandic Central Bank's orthodox policy of tightening of interest rates flooded the Icelandic economy with cheap money chasing high returns in ISK-denominated assets, enhancing the Icelandic banks' and the "Viking raiders" ability to borrow (as the ISK was appreciating relative to most other currencies).

Second, under well-established ideas about appropriate monetary policy, an economy in danger of overheating requires an increase in interest rates. ${ }^{439}$ As Iceland's economy grew rapidly during the early 2000s, the Icelandic Central Bank turned to higher interest rates in an effort to slow the economy down. ${ }^{440}$ This had the effect of making ISK-denominated investing more attractive to foreigners, and increased demand for the ISK, causing the currency to further appreciate. ${ }^{441}$ This in turn made non-ISK-denominated borrowing and consumption more attractive to Icelanders, encouraging more borrowing and spending, the opposite effect that the Central Bank wanted to achieve with its rate hikes. ${ }^{442}$ In response, the Central Bank then raised

authorities, when the UK was attempting to protect its own position against Iceland.” Id. at 49.

${ }^{436}$ See notes 380 - 382 supra.

${ }^{437}$ See, e.g., Taylor, supra note 84.

438 See OECD, Economic Survey of Iceland 2005, Policy Brief (Feb. 2005) at 4 (praising Icelandic fiscal policy).

439 See John C. Williams, Economics Instruction and the Brave New World of Monetary Policy, FRBSF Economic Letter (June 2011) available at http://www.frbsf.org/publications/economics/letter/2011/el2011-17.html.

${ }^{440}$ See notes 296 - 298 supra.

441 Thorvaldsson, supra note 43, at 151-152 ("The very high interest rates made it very attractive to invest in Icelandic kronur. While you would be paid 3 or 4 percent in currencies like euros and pounds, an investor would be paid almost 10 percent higher rates if he placed his money in kronur. That created a demand for kronur and severely strengthened the Icelandic kronur.")

442 Thorvaldsson, supra note 43, at 152 ("the Central Bank's interest rate hike resulted in lower financing costs for households, the opposite of what you would see in other countries.") 
rates again, repeating the cycle. This continued to flood Iceland with cheap money at exactly the wrong moment, further inflating the asset bubbles and fueling the boom. While these effects occur for any currency where the central bank is raising rates in a world of low interest rates, their impact on Iceland was acute because of the small size of the Icelandic economy. Moreover, individual Icelanders often borrowed either in inflation-indexed instruments (primarily for homes and credit cards) or foreign-currency-based loans (especially for cars), which made their real interest rates invariant to the central bank's efforts: "While a one percent interest rate hike [by the Bank of England] in the UK would result in house owners appearing on television explaining how much their monthly mortgage cost had gone up by, a five percent interest rate hike in Iceland only resulted in people shrugging their shoulders. They didn't care."

Iceland was certainly unlucky that, at the moment when the large economy central banks were making the mistake of flooding the world with cheap liquidity, its central bank made the mistake of raising interest rates. There is more than bad timing at work here, however. Under such circumstances, it was inevitable that someone would take advantage of the cheap money. (And, many did in Spain, Portugal, Greece, Ireland, and elsewhere.) Thus even if the Icelandic regulators had been better trained technically, there had been more of them writing better regulations, or EU regulators had acquired jurisdiction over Icelandic banks and made use of it, the incentives provided by the growing inflows of money would have been facilitating individuals' and institutions' aggressive investment strategies, governments' loose fiscal policies, and reckless behavior by individuals, institutions, and governments. Further, even if foreign regulators had paid more attention to evaluating the risks posed by Icelandic conditions, the cross-holdings of Icelandic banks and companies, and the ISK, regulatory reaction outside Iceland would have been slowed by the complications of international relations, the complexity of the issues, and the limited tools available to slow capital flows to specific countries. Even a step as simple as the U.K. government forbidding local governments from investing in foreign internet banks would not have been easy to implement, given governments' commitments to capital mobility ${ }^{444}$ and the then-UK-government's commitment to devolution of authority to lower levels of government. ${ }^{445}$ Moreover, since the problems in Iceland were partially the result of the Icelandic government's adoption of fiscal stimulus measures similar to those adopted elsewhere, foreign governments would have had difficulty criticizing Iceland for undertaking the same type of policies they were pursuing domestically.

This was not just a problem in Iceland. The European economies missed out on part of the cycle, as the ECB did not raise rates. Similarly U.S. states with debt problems similar to those of the southern European economies did not experience the high rates. But all these economies, within larger currency areas with more vibrant economies, were able to take advantage of the cheap money and implicit guarantees of their more solvent partners. By keeping interest rates extremely low for years, the ECB, Bank of England, and Federal Reserve's monetary policies both contributed to pressures for returns and offered guarantees that encouraged lenders and investors in Britain, on the continent, and in the United States to engage in reckless lending and investment practices. Without cheap money, Spanish cajas might have

\footnotetext{
443 Thorvaldsson, supra note 43, at 151.

${ }^{444}$ See section I.A. supra.

445 See Hugh Atkinson \& Stuart Wilks-Heeg, LOCAL GOVERNMENT From THATCHER TO BLAIR: THE POLITICS OF Creative Autonomy 252-269 (2000) (describing Labour Party’s push to devolve authority to local governments).
} 
wanted to fuel a Spanish real estate bubble, Greek governments might have desired to systematically mislead investors, regulators, and their own citizens, Portuguese governments desired to run up gigantic deficits, and Irish banks to offer valued real estate investors loans at many times the value that later proved sustainable - but if money had been dearer, the cost of doing so would have been higher. The same is true for functionally bankrupt states like Illinois and California in the United States. Because the demand curves for those activities slope downward, a higher cost would have produced less of each. We can certainly devise additional laws and regulations that might prevent some of these particular bad practices from recurring in the future, but paying attention to the monetary and fiscal policies that created the incentives for the bad practices is the only means to also address the next innovations.

Unfortunately, there is little evidence that the major economies' central banks will do better. Indeed, today the Federal Reserve and the ECB are behaving as if constraints on the acceptable range of central banking behavior have been loosened, rather than tightened. The Federal Reserve's $\$ 600$ billion program of "quantitative easing" that began in November 2010 , its $\$ 850$ billion of purchases of illiquid assets from financial institutions in 2009 and the ECB's purchases of billions of euros of sovereign debt unwanted by market actors are all examples of actions that few would have imagined possible if suggested ten years earlier. ${ }^{446}$ All represent significant expansions of the types of activities central banks are willing to engage in, as well as the scale of interventions they are willing to make. All raise serious questions about the future direction of central banks' roles. At the least, putting illiquid assets like Greek government bonds or "toxic" securities on central banks' balance sheets raises questions about the central banks' abilities to unwind such deals when they must move in the opposite direction. Further, these actions raise questions about what, if any, activities the central banks would not be willing to take in the future if they felt it was warranted. Perhaps, although we doubt it, having a totally unconstrained actor with the ability to print money at will is a good thing. However, if that is the role central banks are to play in the world economy in the future, there ought to be considerable debate and discussion of it first.

Thus among the problems highlighted by the Icelandic crisis in particular and the broader global financial crisis in general are that fiscal and monetary policies can create incentives that overwhelm financial regulatory measures and the need for tighter, not looser, constraints on monetary policy. It will be years, perhaps decades, before even the Icelandic portion of the crisis is fully understood and its lessons digested. Iceland does demonstrate that assessment of financial regulation without consideration of monetary and fiscal policy measures is incomplete.

\section{B. Moving beyond the regulation/deregulation dichotomy}

Iceland primarily entered American law professors' consciousness as an ur-libertarian society through analyses of the Saga Era by law professor William Miller ${ }^{447}$ and law and

\footnotetext{
${ }^{446}$ To some extent, the Fed's move with respect to its purchases of long term government bonds resemble the 196165 "Operation Twist," in which the Fed bought long term government bonds. See Allister Bull, Fed Says Let's Twist Again after 48 years, REUTERS (Mar. 19, 2009) available at http://www.reuters.com/article/2009/03/19/us-usa-fedtwist-idUSTRE52I3AG20090319. This program did not involve purchase of assets like the mortgage backed securities bought in 2009, however, and the general assessment of Operation Twist is that it failed in its objectives.

${ }^{447}$ See THEODORE M. ANDERSSON \& WiLliam IAN Miller, LAW AND LitERATURE IN MEDIEVAL ICELAND (1989);

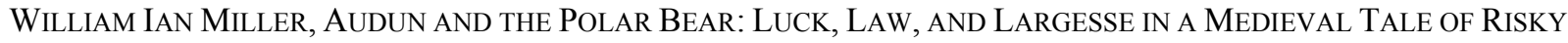
Business (1998); William Ian Miller, BLOODTAKING AND PEACEMAKING: FeUd, LAW, AND SOCIETY IN SAGA
} 
economics scholars David Friedman ${ }^{448}$ and Bruce Benson. ${ }^{449}$ The attraction of the Icelandic Commonwealth for libertarians (including both of us) is that it represented a functioning and prosperous society with few rules beyond tort, property and contract, lacking even an executive branch of government or full-time judiciary. Accounts of the Icelandic crisis that strive to blame deregulation for the problems sometimes make analogies to Iceland's Viking past and the Commonwealth's minimal state to bolster their case. ${ }^{450}$

We have argued here that this represents a profound misreading of the financial crisis' roots as well as of the larger arc of Iceland's economic history, as described in Part II. Iceland's economy proceeded through multiple cycles of growth and stagnation over the past 150 years. As we described, all of the periods of growth have been associated with growing economic freedom; all of the periods of stagnation with severe limits on economic freedom. ${ }^{451}$ What differentiates the most recent collapse from prior periods of growth is thus not the presence of economic freedom but the changes in the world economy and the particular monetary and fiscal policies in Iceland.

Without question, some individual Icelanders in and out of government as well as Icelandic government entities, Icelandic banks, Icelandic government entities, and Icelandic companies behaved badly at times and made mistakes at others, just as individuals, regulators, banks, and companies everywhere do routinely. An important part of why the consequences for others of those mistakes and bad behavior were so severe is that the Icelandic state went well beyond simply setting the "rules of the game" and actively intervened in the economy in ways that made things worse. Specifically, the Central Bank's role in setting interest rates - in accord with modern central banking theory - played a critical role, as did the most un-Thatcher-like heavily stimulative fiscal policy of the government of the "Thatcherite" David Oddsson. ${ }^{452}$ What transformed their individual mistakes into crises was their ability to make mistakes on a grand scale due to the lack of feedback.

ICELAND (1990); William Ian Miller, Of Outlaws, Christians, Horsemeat, and Writing: Uniform Laws and Saga Iceland, 89 MicH. L. REV. 2081 (1991); William Ian Miller, Some Aspects of Householding in the Medieval Icelandic Commonwealth, 3 ConTINUITY \& CHANGE 321 (1988); William Ian Miller, Ordeal in Iceland, 60 Scandinavian Stud. 189 (1988); William Ian Miller, Dreams, Prophecy and Sorcery: Blaming the Secret Offender in Medieval Iceland, 58 ScAndinavian STUD. 101 (1986); William Ian Miller, Gift, Sale, Payment, Raid: The Negotiation and Classification of Exchange in Medieval Iceland, 61 SPECULUM 18 (1986); William Ian Miller, Avoiding Legal Judgment: The Submission of Disputes to Arbitration in Medieval Iceland, 28 AM. J. OF LEGAL HIST. 95 (1984); William Ian Miller, Choosing the Avenger: Some Aspects of the Bloodfeud in Medieval Iceland and England, 1 LAW \& HIST. REV. 159 (1983); William Ian Miller, Justifying Skarpheðinn: Of Pretext and Politics in the Icelandic Bloodfeud, 55 SCANDINAVIAN STUD. 316 (1983), reprinted in SAGAS OF THE ICELANDERS 292 (John Tucker ed., 1989) (article reprinted with revisions and renamed The Central Feud in Njáls Saga).

448 DAVID D. Friedman, LAW's Order: An ECONOMIC ACCOUnT 263 (2000); DAVID D. Friedman, The Machinery of Freedom: Guide to a Radical CAPITAlism 201 (1995); David D. Friedman, Private Creation and Enforcement of Law - A Historical Case, 8 J. LEGAL STUD. 399 (1979).

${ }^{449}$ Bruce L. Benson, The EnTERPRise OF LAW: Justice Without The StATE 11-42 (1990).

${ }^{450}$ Lewis, supra note 21.

${ }^{451}$ See section II.A.

${ }^{452}$ Boyes, supra note 4, at 6 (noting Oddsson was a "self-proclaimed Thatcherite"); David Rennie, What you can pick up in Iceland, Spectator.co.uk (16 Sept. 2006) available at http:/www.spectator.co.uk/essays/all/25131/part_2/what-you-can-pick-up-in-iceland.thtml (Oddsson "a wild-haired Thatcherite"'). 
Rather than conceptualizing states as dichotomously "deregulated" or "regulated", analyses must address the multifaceted nature of state involvement in the economy at more than a superficial level. Iceland falls on the deregulated end of the spectrum, but the other European economies experiencing crises do not: Greece was (and still is) a heavily regulated economy in virtually every respect, ${ }^{453}$ Portugal's problems rest on profligate public spending, ${ }^{454}$ and Spain fits no definition of a liberalized financial sector, since state banks (the cajas) making politicallydetermined loans played such a major role in the economy there. ${ }^{455}$ One might argue, for example, that states that intervene aggressively in monetary and fiscal policy may acquire a corresponding need to intervene aggressively in financial regulation to contain the impacts of their monetary and fiscal actions. This would require addressing whether the state in question had the institutional capacity to coordinate such interventions without committing errors in the regulatory activity.

In a world of where the free movement of capital is the norm and exchange rates move with market trends, the problem of designing institutions is not choosing among a set of policy preferences that fall somewhere between a planned economy and laissez faire based on one's desire to bring about a particular outcome. The issue is whether, given the constraints imposed by world capital markets, a country's institutions are designed to transform market signals into feedback that self-corrects or whether it produces feedback that spirals out of control as in Iceland. ${ }^{456}$

Throughout the world, many remedies proposed since the financial crisis have focused on enhancing central bank surveillance of the financial sector and both central banks' and other authorities' regulatory authority over it. ${ }^{457}$ Such proposals presume, we think, that the central bank's role in monetary policy and the government's role in fiscal policy are not driving individuals and institutions to behave inconsistently with regulatory policy. Moreover, such proposals vary considerably in how they approach various regulatory issues. Limiting the ability of central banks and governments to use monetary and fiscal policies in ways that create incentives for behaviors that lead to financial crises reduces the need to get the financial surveillance and regulatory policies "right" and so helps make those policy choices more tolerant of errors. Adopting an interest rate rule like the Taylor Rule, a currency board, or other restrictions on central bank activities seem more important to us in light of Iceland's experience

\footnotetext{
${ }^{453}$ See Michael Mitsopoulos \& Theodore Pelagidis, Vikings in Greece: Kleptocratic Interest Groups in a Closed, Rent-Seeking Economy, 29 CATO J. 399 (2009).

${ }^{454}$ EU economy crisis \#3: Portugal asks for bailout, CBS NEWS (April 6, 2011) available at http://www.cbsnews.com/stories/2011/04/06/501364/main20051428.shtml.

${ }^{455}$ Chana Joffe-Walt, A Theme Park, an Airport, and the Next Banking Crisis, PlaneT MoneY (Jan. 7, 2011).

${ }^{456}$ Within the set of institutions that must meet this market feedback test is the choice of currency itself. With the benefit of hindsight, we believe Iceland's experience demonstrates that its economy is too small to support an independent currency because maintaining such a currency would have required a central bank capable of navigating the quite difficult problems the country faced as a result of the capital inflows of leading up to 2007. But expanding a currency beyond national borders also has its risks, as Ireland, Portugal, Spain, and Greece demonstrate. The ability to free-ride on Germany's credit rating played a role in the problems in each of those four countries.
}

${ }^{457}$ See, e.g., Ben S. Bernanke, Lessons of the Financial Crisis for Banking Supervision, Speech (May 7, 2009) available at http://www.federalreserve.gov/newsevents/speech/bernanke20090507a.htm. 
than giving central banks greater power and discretion. Facilitating private interests' ability to opt out of currencies in contracting can create more avenues for feedback if done properly. ${ }^{458}$

\section{Financial Surveillance}

If we learned nothing else from the global financial crisis, we should have learned that all models of financial regulation suffer from serious weaknesses. Both the U.K. single-regulatorusing-principles approach and the U.S. multiple-regulators-enforcing-rules approach proved inadequate. Spain's more "social market" oriented policies did not prevent either its banking sector's crisis or a stunningly large housing bubble; Ireland's more deregulated approach also produced a banking sector meltdown and a massive housing bubble. Greece's highly centralized and regulated economy yielded a stunning partnership between the Greek government and international banks to commit actions that, had they been conducted by a private party, could only be described as fraud, and which were at a minimum corruption on a massive scale, ultimately producing the sort of widespread social unrest advocates of "social markets" claim their theories avoid; many of Britain's local governments used their autonomy to gamble with accounts in Icelandic Internet banks with little or no due diligence in pursuit of higher returns. In short, regulators were trying many approaches to financial regulation leading up to the crisis and none of them worked as theorized.

Iceland certainly adds additional examples of regulatory failure. In retrospect, some have criticized Iceland for insufficient regulatory efforts because the regulators were not up to the task. In addition to regular mention of former Central Bank governor and former Prime Minister David Oddsson's taste for literature over economics and legal rather than economics training, the post-crash literature suggests his management style was not sufficient to deal with the financial world. $^{459}$ Perhaps lawyers, poets, or poet-lawyers should not be central bankers, although this seems an overgeneralization from a sample of one. Perhaps managers who yell should not be central bankers, although managers who never yell might encounter other problems. Perhaps politicians should not be central bankers, although a central banker without political skills would encounter a different set of problems. One might argue that Iceland's form of financial surveillance - when surveillance authority and liquidity concerns were set up in the FME while responsibility for financial stability was placed in the Central Bank was particularly flawed. But the failure of any regulatory model to provide either an early warning or a solution to the problems in advance suggest that regulatory structure could not have been the primary factor in the crisis in Iceland or elsewhere.

The lesson is not that "nothing works" and we should either throw up our hands or that we should roll back global finance to simpler time. Rather, we draw three relatively sharp lessons from the Icelandic crisis related to financial surveillance, ones that are supported by experiences elsewhere as well. First, there was a significant lack of cooperation amongst regulators both within countries and across borders, between regulators and politicians, and between regulators and regulated. Almost no one seems to have known much about what other

\footnotetext{
${ }^{458}$ Iceland's experience with foreign currency denominated loans was not a good example of this for two reasons. First, borrowers were investing in ISK-denominated assets, leaving themselves vulnerable to the problems of the ISK. Second, the contracting took place in an environment where regulators allowed the (accurate) impression that bailouts would be provided when large scale problems occurred.

${ }^{459}$ Boyes, supra note 4, at 67 ("too much of Oddsson's governing style depended on his personality, his striding into a room of civil servants and barking, 'Something must be done!'”)
} 
players were doing. (Some accounts attribute personal motives to explain actions by key players during the crisis. ${ }^{460}$ ) Outside Iceland, the lack of communication was part of an effort to conceal problems from the regulators (Greece), ${ }^{461}$ because of murky relationships between politically connected financial institutions (Spain), ${ }^{462}$ or because no one appeared to be interested in communicating as long as the money kept flowing (Ireland and Portugal). ${ }^{463}$ In the United States internal communications failures were part of the reason for the S.E.C.'s failure to address the Madoff fraud despite being repeatedly handed detailed outlines of the fraud by a concerned citizen. ${ }^{464}$ U.S. regulators were (at least) slow to recognize the problems posed by securitized subprime loans, ${ }^{465}$ to spot the housing bubble (despite the experience of the tech bubble just a short time before), ${ }^{466}$ and to focus on the rapid growth in highly leveraged positions by numerous financial institutions (despite the example of Long Term Capital Management just a few years before). ${ }^{467}$

Formulating regulatory policy when you do not know what the regulated are doing is problematic whether the regulator is a poet, lawyer, economist, or all three. Whatever one might make of the Icesave affair, it is not an example of even minimal cooperation between national regulators at any point, pre-, during, or post-crisis. ${ }^{468}$ Fault undoubtedly lies in various proportions with the assorted Icelandic, Dutch, and British regulators but the question that Icesave in particular raises for us is why anyone would expect any of these regulators to cooperate when there were no incentives for such cooperation to occur. These problems are not limited to the relatively discrete crisis-within-a-crisis of Icesave. U.K. local governments, firms,

\footnotetext{
${ }^{460}$ See, e.g., Boyes, supra note 4, at 108-109 (describing alleged feuds among Oddsson and a group of Icelandic businessmen).

${ }^{461}$ Matthew Lynn, Bust: Greece, the Euro, AND the Sovereign Debt Crisis (2010).

${ }^{462}$ Chana Joffe-Walt, A Theme Park, an Airport, and the Next Banking Crisis, PlANET Money (Jan. 7, 2011) (“"At the center of Spain's banking crisis are regional banks called cajas de ahorros. More than half of Spanish banking deposits are in cajas. And they're not run by bankers, but by local politicians and priests").
}

${ }^{463}$ McWilliams, Follow THE MONEY, supra note 65 (Ireland); EU economy crisis \#3: Portugal asks for bailout, CBS NEws (April 6, 2011) available at http://www.cbsnews.com/stories/2011/04/06/501364/main20051428.shtml ("Portugal's troubles stem from a decade of measly growth - averaging 0.7 percent a year - during which it amassed huge debts to finance its western European lifestyle.”)

${ }^{464}$ See Harry Markopolous, No OnE Would Listen: A TRUE FinANCIAL THRILler (2010) (describing repeated unsuccessful efforts of the author, a private citizen, to persuade the SEC to investigate Madoff over a ten year period).

${ }^{465}$ See THE FINANCIAL CRISIS INQUIRY REPORT, AUtHORIZED EDITION: FINAL REPORT OF THE NATIONAL COMMISSION ON THE CAUSES OF THE FINANCIAL AND ECONOMIC CRISIS IN THE UNITED StATES 42-46 (2010).

${ }^{466}$ See Anthony B. Perkins \& Michael C. Perkins, The InTERnEt BubBle: Inside The Over-VALUED WorLd OF HIGH-TECH STOCKS (2001) (describing technology bubble) and FINANCIAL CRISIS INQUIRY REPORT, supra note 465, (describing housing bubble).

${ }^{467}$ See FINANCIAL CRISIS INQUIRY REPORT, supra note 466, at__ (describing role of leverage in current crisis); Roger Lowenstein, When GENIUS FAILED: THE Rise AND FALl OF LONG-TERM CAPITAL MANAGEMENT (2001) (describing role of leverage in Long Term Capital Management's problems). Moreover, as Lowenstein notes, LTCM itself disclosed its leverage quarterly to its banks, monthly to its investors, and to the CFTC. Lowenstein concludes that "the numbers indicated (to anyone who cared to look) that something big was brewing" and that the banks, at least, "were in a good position to estimate" the overall leverage. Id. at 81.

${ }^{468}$ See sections II.D., II.E., and II.F. supra. 
charities, and individuals were moving large amounts of money into an Icelandic internet bank and there seems to have been virtually no interaction between Icelandic and British regulators, even along the lines of a phone call to ask "Can your deposit insurance fund handle this volume of deposits?" or "We were wondering if access to the U.K. deposit insurance fund might not be a bad idea, since this branch of our bank is accepting quite a bit of money from your citizens. What do you think?"

Moreover the problem runs in both directions. Market actors need the certainty provided by up-to-date knowledge of the plans of regulatory, monetary, and fiscal policy actors as much as regulators need information about activity in the markets they regulate. Although some aspects of monetary policy have become more transparent, ${ }^{469}$ there are still significant areas in which central bank policy is not transparent and the implementation of transparency is still an ongoing process. ${ }^{470}$ With respect to monetary policy in some economies, this can be addressed by eliminating monetary policy entirely, through adoption of an alternative currency (e.g. dollarization or euro-ization). For others, a currency board following strict policy rules can provide certainty with respect to monetary policy. Even in large economies, adoption of policy rules like the "Taylor Rule" can eliminate much of the uncertainty associated with monetary policy. Fiscal policy can be subject to similar constitutional constraints (which, admittedly, have a mixed record of implementation across a wide range of jurisdictions). Regulatory policy can be made more certain (although at a cost to adaptability and flexibility) through transparency.

Making things even more difficult, an adversarial relationship between regulated and regulators may be inevitable where regulators have substantive authority over firms' businesses. Firms have few incentives to disclose information to regulators for fear of provoking more regulation and that the revolving door will carry the regulator's personnel to a competitor, while regulators have little reason to share strategies with the regulated for fear that the regulated will lobby against their actions. Too much cooperation, on the other hand, risks facilitating rentseeking and anti-competitive activity aimed at new entrants.

Fortunately, we have a mechanism that facilitates information sharing without compromising confidentiality or encouraging rent-seeking: market exchanges. As Friedrich Hayek so aptly described, markets are information-producing mechanisms that incorporate feedback loops capable of encouraging midcourse corrections. ${ }^{471}$ A key lesson of the financial crises we have discussed here is that financial market structure desperately needs those feedback

\footnotetext{
${ }^{469}$ Alan S. Blinder, et. al., Central Bank Communication and Monetary Policy: A Survey of Theory and Evidence, ECB WORKIng PAPER SERIES No. 8985 (May 2008) available at www.ecb.int/pub/pdf/scpwps/ecbwp898.pdf (“A few decades ago, conventional wisdom in central banking circles held that monetary policymakers should say as little as possible, and say it cryptically. Over the recent past, the understanding of central bank transparency and communication has changed dramatically. As it became increasingly clear that managing expectations is a central part of monetary policy, communication policy has risen in stature from a nuisance to a key instrument in the central banker's toolkit.").

${ }^{470}$ Blinder, et al., supra note 469, at 5 ("No consensus has yet emerged on what communication policies constitute "best practice" for central banks. Practices, in fact, differ substantially, and are evolving continuously."); Michael Frenkel, et al., The transparency of ECB policy: What can we learn from its foreign exchange market interventions? 28 J. POL'Y MODELING 141, 154 (2005) (suggesting that with respect to foreign exchange interventions, diversity of views within EMU and poor communication by ECB meant it was hard to model ECB behavior).

${ }^{471}$ Friedrich A. Hayek, The Use of Knowledge in Society, 35 AM. ECON. REV. 519 (1945).
} 
loops. Regulations should enhance, not muffle, feedback among market participants and between market participants and regulators.

Second, the cross-ownership between the banks and holding companies, ${ }^{472}$ in which owners of banks owned investment firms, that in turn owned parts of banks, and so forth spread the crisis further and faster than it might have otherwise. Cross-ownership appears to have led to a rise in the underlying asset prices during the boom in the relatively thinly traded Icelandic stock exchange and transmitted the collapse faster than it might have otherwise occurred when the crash came. Not all cross-ownership is bad, of course, but as Figure 1 above illustrated, cross-ownership in the Icelandic economy likely impeded feedback by obscuring risks. Having learned the dangers of interrelationships, counterparties may use contracts in the future to protect themselves; regulators should focus attention on expanding disclosure of interconnections that transmit risk.

Third, during the final stages of the boom, there was heavy lending to large shareholders and quite large loans extended to cross-owners and single groups. ${ }^{473}$ Bankruptcy and bank failure regulatory schemes can provide for unwinding such deals in some cases; enhancing the ability for creditors to recapture such assets through record keeping requirements, record retention rules, and provisions in bankruptcy rules may be the best ex post solution available. Ex ante, preventing firms from lulling investors into a state of complacency through whispered implicit guarantees of bailouts is important in incentivizing investors to do proper due diligence.

Designing institutions for surveillance of financial firms is particularly difficult because the rapid pace of innovation means that any scheme devised today may be inadequate tomorrow. But the problems we have described were not entirely problems of innovation; many were problems that have existed for decades and about which the literature on financial regulation was extensive. The need for coordination among regulators has been written about and discussed for decades; ${ }^{474}$ cross-ownership has been an issue, at least with respect to Asia, ${ }^{475}$ Russia, ${ }^{476}$ developing economies, ${ }^{477}$ and Japan; ${ }^{478}$ accounting questions have long been recognized as

\footnotetext{
472 Boyes, supra note 4, at 116 (describing “an extraordinary web of cross-ownership" as contributing to the crisis).

${ }^{473}$ Boyes, supra note 4, at 160 (Landsbanki handed out $36 \%$ of its capital to its shareholders in the "few months" before it collapsed; Kaupthing let its board members ISK 39.2 billion and Glitner "passed on 17 percent of its capital.")

${ }^{474}$ Ethan B. Kapstein, Resolving the Regulator's Dilemma: International Coordination of Banking Regulations, 43 INT'L ORG. 323, 328 (1989) (tracing calls for coordination to 1970s).

${ }^{475}$ See, e.g., World Bank, EAST ASIA: RECOVER AND BEYOND 86 (2000) ("the cross-ownership pattern in much of East Asia - where banks and other financial institutions are part of the conglomerate (and subservient to it) - offers no meaningful opportunity for banks to provide effective oversight to their corproate clients. Moreover, this ownership structure appears to have distorted credit allocation in favor of firms affiliated with the conglomerate (despite formal limits on connected lending) both before and after the crisis.")

${ }^{476}$ See, e.g., Thomas C. Owen, Russian Corporate CAPITALism From Peter the Great to PERESTROIKA 110 111 (1995) (describing how cross-ownership appeared as those controlling state enterprises engaged in a process of "spontaneous privatization" of the state enterprises' profits). Note that we are citing a pre-crisis source to show that the problem was well understood before the current crisis.

${ }^{477}$ See, e.g., Robert W. McGee, Corporate Governance in Developing Economies, in CORPORATE GOVERNANCE IN DEVEloping ECONOMIES: Country Studies of AFriCA, Asia AND LATIN AMERICA (Robert W. McGee, ed.) 3 , 4 (2009) (listing as among the "particular challenges" of developing economies "severing links such as cross shareholdings between banks and corporations" and "dismantling pyramid ownership structures".)
} 
critical and problematic within financial regulation; ${ }^{479}$ and the cashing out of booms has been a feature of boom-bust cycles for centuries. ${ }^{480}$ If the problems were not entirely new, neither was the lack of regulatory capacity - it can come as no surprise to anyone who simply counted heads at the Icelandic Central Bank or the FSA that the Icelandic authorities were understaffed relative to the size of the market by most measures. ${ }^{481}$

The remedies should thus not be seen as simply more regulations, more regulators, or some combination thereof. Rather than asking how much more, we should be asking how to do financial regulation differently. It should not depend on regulators catching the obvious but on creating incentives for individuals to protect themselves. Financial surveillance measures should be focused on creating transparent markets rather than on encouraging disclosure to central regulators. Financial regulators need authority to obtain information in conjunction with specific investigations. But it is by making financial markets more transparent that market feedback can be brought to bear on issues long before regulatory action is possible.

\section{Jurisdictionally-based regulation}

The vast majority of financial regulation today is done by single jurisdiction regulators (with the qualification that how one classifies EU regulators might change this sentence). These regulatory structures predate today's deep financial integration, free movement of capital, and flexible exchange rates. Although an alphabet soup of international associations and organizations attempts to assist in coordination, financial regulation largely remains based in particular jurisdictions while the financial world is truly global. This mismatch creates a wide range of problems, as can be seen in the Icelandic crisis. Not only were deposit insurance

\footnotetext{
${ }^{478}$ See, e.g., Tsuneaki Sato, The Japanese Economy in Search of a New Identity: A Reappraisal of the so-called 'Japanese Economic System' and its Applicability to Emerging Capitalist Economies, in Democracy and market economics in Central and Eastern Europe: Are new institutions being consolidated? (Tadauuki Hayashi, ed.) 331, 348 (2004) ("In the 1990s, however, cross-ownership, so much praised in the past, has become the target of severe criticism both from outside and inside, as the nearly omnipotence of enterprise managers has led to many abuses and much fraud at the management level.") Note that we are citing a pre-crisis source to show that the problem was well understood before the current crisis.

${ }^{479}$ See, e.g., Mark Jickling, Accounting Reform After Enron: Issues in the 108th Congress (CRS Report for Congress) (2003) (describing issues raised by Enron scandal with respect to accounting, including issues with respect to pricing of derivatives). Note that we are citing a pre-crisis source to show that the problem was well understood before the current crisis.

${ }^{480}$ See, e.g., Akash Deep \& Dietrich Domanski, Housing markets and economic growth: Lessons from the US refinancing boom, BIS QUARTERLY REVIEW 37 (Sept. 2002) (describing 2001 refinancing boom and cash-out mortgages role). Note that we are citing a pre-crisis source to show that the problem was well understood before the current crisis.

${ }^{481}$ SIC's report, Chapter 2, Executive Summary in English, page 16. http://sic.althingi.is/pdf/RNAvefKafli2Enska.pdf ("The FME was not well enough equipped to sufficiently monitor the financial institutions when they collapsed in the autumn of 2008. Considering the operating expenses of the FME and its budget up to 2006, it is clear that the growth of the Authority did not keep pace with the rapid growth of the Icelandic financial system, more complicated ownership links within the financial market, and increased activity of regulated entities abroad, and it was not consistent with the growing and increasingly complicated tasks entrusted to it pursuant to law during the preceding years. The FME's tasks demand vast expert knowledge on the operations of banks, economics, accounting, and legislation on financial markets.") See also Andrew P. Morriss \& Clifford C. Henson, Regulatory Intensity in Onshore \& Offshore Financial Centers, Working Paper, available on SSRN, (discussing relative regulatory intensity across jurisdictions.)
} 
standards - as set out by EU authorities - inadequate to cope with a systemic risk even within a relatively small economy like Iceland's, but the Icesave and Kaupthing Singer Friedlander entities in Britain exposed further inadequacies. Icesave demonstrated the problems of interjurisdictional operation in a world of local deposit insurance. But that was not the only problem, since Kaupthing had correctly created local subsidiaries, covered by the relevant deposit insurance schemes, in Britain and the Isle of Man. U.K. regulators' behavior with respect to Kaupthing's U.K. and Isle of Man entities layered on an additional set of problems. One response has been to push for greater authority for supra-national regulatory bodies. ${ }^{482}$

Consider the problem of deposit insurance. These schemes have long been understood to pose a moral hazard problem for depositors, lessening their incentive to investigate the conditions of the institutions in which they have placed their money. ${ }^{483}$ Indeed, as recently as the 1980s S\&L crisis in the United States, analysts warned that providing a government guarantee fostered reckless behavior by depositors. ${ }^{484}$ The British investigation into local authorities' use of Icesave suggest that this is exactly what happened - those governments that put and left money in Icesave did insufficient investigation and monitoring of Icesave, relying on credit ratings. ${ }^{485}$ Those credit ratings proved fatally flawed by their failure to consider systemic risk, interrelatedness of the entities involved, and a host of other factors. Whatever the reasons, the provision of flawed deposit insurance schemes played an important role in turning Landsbanki's collapse into a diplomatic and political crisis, in Britain's invocation of anti-terror legislation to freeze Icelandic assets in an effort to protect some British depositors of the Icelandic banks' internet subsidiaries, and in the resulting destruction of Kaupthing. For example, after the crisis one UK analyst commented "We talk about the Icelandic banking system being run by the mediocre and the incompetent. ... But the truth is, most of our budget people just plodded on like

\footnotetext{
${ }^{482}$ See, e.g., Gordon Brown \& Nicolas Sarkozy, For Global Finance, Global Regulation, Wall S. J. (Dec. 9, 2009) available at http://online.wsj.com/article/SB10001424052748704240504574585894254931438.html ("the way global financial institutions have operated raises fundamental questions that we must —and can only —address globally.”).

${ }^{483}$ See Ronald MacDonald, Deposit Insurance, HANDBooks In CENTRAL BANkING No. 9, Centre for Central Banking Studies, Bank of England 9 (1996), available at http://www.bankofengland.co.uk/education/ccbs/handbooks/pdf/ccbshb09.pdf ("Bank depositors may, therefore, contribute to moral hazard if deposit insurance means that they no longer feel obliged to assess the credit risk associated with depositing money with a particular bank."); Lucian A. Bebchuk \& Holger Spamann, Regulating Bankers' Pay, 98 GEO. L.J. 247, 257 (2010) (stating that, when deposits are guaranteed by the government, depositors have no incentive to investigate a bank's strategy before depositing funds," nor do they incentive to withdraw funds after they learn that a bank is beginning to take more risk).

${ }^{484}$ See Alvin C. Harrell, Deposit Insurance Issues and the Implications for the Structure of the American Financial System, 18 OKLA. CiTY U. L. REV. 179, 248 (1993) (arguing that there is evidence to suggest that regulation is not a substitute for depositor discipline and stating that the increase in the deposit insurance limit was a contributing factor to the S\&L crisis of the 1980s); Robert E. Litan, Deposit Insurance, Gas on S\&L Fire, WALL ST. J., July 29, 1993, at A10 (labeling the S\&L crisis a "giant financial fireball" and calling deposit insurance the "gasoline").

${ }^{485}$ Audit Commission [UK], Risk and Return: English Local Authorities and the Icelandic Banks 30 (March 2009) available at http://www.auditcommission.gov.uk/SiteCollectionDocuments/AuditCommissionReports/NationalStudies/26032009riskandreturn2.p df ("In the Commission's view, they should have been taking reasonable steps, certainly by the end of September 2008 , to ensure that they were using up-to- date information prior to making further deposits in the relevant banks.").
} 
First World War soldiers led to slaughter at the front. I asked one of them about it and she just shrugged. 'It's not your money, don't get excited.' That's what she said."

But those decisions did not occur in a vacuum either. In Britain, "[ $t]$ he world of local government finance had been transformed since 1997; the innovative government of Tony Blair, the New Labour ethos, and above all his chancellor of the exchequer, Gordon Brown, had freed the City, allowing and encouraging London to become a metropolis that danced to the tune of the financial-services culture. The trickle-down effect had been felt not only in urban culture, but outside the city, in the provinces too." ${ }^{487}$ In its pursuit of devolution of some authority, the BlairBrown government failed to create institutions capable of properly assessing financial risk, or indeed of undertaking any real assessment of risks at all. Icesave and KSF would have been problems even if they had only had individual depositors, but they would have been much smaller problems if the government deposits had not been made initially or had stopped before the collapse. At least in part, the lack of feedback mechanisms between those deciding where to place official deposits and those affected by the failure undercut fiscal prudence.

It does not require 'rocket science' to see that the EU deposit insurance rules failed to adequately address cross-border banking. For example, Swedish central banker Lars Nyberg presciently warned in 2005 that

What are the wider implications of tax payers in one country insuring substantial amounts of deposits in another country? It has been noted that it may be politically very difficult to make payouts from one country to another in the aftermath of a large bank failure. It could also be questioned if it is reasonable that, after a large bank failure, the authorities in the host country just refer its depositors to the home country authorities, without taking any responsibility. And, of course, there is always the question of whether the failure of some large cross-border EU banks will be too big to manage for a single EU member state. ${ }^{488}$

The problems were not hidden before the crisis and proponents of additional regulation need to explain why new measures will function better than the old ones. In short, if EU nations' regulators failed to address this problem before the Icesave problem brought it dramatically to their attention, do we think they can do better in the future? Similarly, if both EU and EU nations' regulators missed the Greek fraud, the Irish banking crisis, the problems with Spanish banks, and the Portuguese debt problems, why do we think they might do better in the future?

There are three ways to "fix" the specific deposit insurance problem. The first, which we favor, would be to eliminate state-provided deposit insurance and force deposit-taking institutions to develop private alternatives through insurance markets. We think there is no evidence that deposit insurance provided by governments prices risks accurately. Safer institutions should be able to pay lower premiums, reflecting their lower likelihood of default. Riskier institutions should pay more. Shifting deposit insurance into markets is one way to bring more feedback into the regulation while untying it from particular jurisdictions. This would

\footnotetext{
${ }^{486}$ Boyes, supra note 4, at 140 (quoting “an accountant from a northern English authority”).

${ }^{487}$ Boyes, supra note 4, at 138.

${ }^{488}$ Nyberg, supra note 78 , at 5
} 
remove the illusion of state support and reduce the political incentives to intervene by reducing the stakes for public funds. ${ }^{489}$ This is unlikely to happen, however.

The second solution is to require deposit-taking institutions to more clearly identify the sources of any deposit insurance protection they provide, including a risk-adjusted measure of the resources backing the deposit insurance. Thus, Icesave might have been required to include "backed by the Icelandic Deposit Insurance Fund with assets of $€ 105 m$ "490 on its website and marketing materials.

Third, deposit insurance schemes could be modified to prevent small funds like Iceland's from being used to guarantee deposits from other economies by restricting the ability of foreign deposit-taking institutions to operate in an economy through a foreign entity. While we think this is the least desirable solution, since it would reduce competition, it may be the most politically feasible.

But deposit insurance is only one small aspect of the larger problem of mismatch between regulators and the regulated in the financial industry. As we have explained, we are skeptical about the virtues of expanding regulatory measures beyond national borders. Larger regulators, after all, are able to fail on a larger scale as well. National regulators can enhance transparency and deepen markets in a number of ways, however: public bodies making investments (as with the U.K. local governments investing in Icesave) should make their investment decisions available in real time for public scrutiny; regulatory safe havens for trading in investments on exchanges that meet voluntary standards' organizations' best practices; honest public accounts; and freedom to trade in instruments which short securities issued by both private and public entities all enhance feedback and allow international capital markets to "regulate" a wide range of market actors and public bodies.

\section{E. The Politics of Crises}

The final lesson from Iceland's experience as well as from the European crises - one that continues to be made anew as the crises continue to unfold - is the inseparability of domestic politics from the international response to crises. The global financial crisis has sparked numerous calls for additional regulators at the national and supra-national levels. ${ }^{491}$ Despite these

\footnotetext{
${ }^{489}$ See, e.g., Catherine England, Private Deposit Insurance: Stabilizing the Banking System, CATO POL'Y ANALYSIS No. 54, June 21, 1985, available at https://www.cato.org/pubs/pas/pa054.html (proposing a system for phasing in private deposit insurance by allowing banks to choose between tiered options mixing different percentages of private and federal deposit insurance).

${ }^{490}$ The amount of the Icelandic deposit insurance fund in 2007. See Beat Berbet \& Sysabba Walter, Design, Structure and Implementation of a Modern Deposit Insurance Scheme, SUERF - The European Money and Finance Forum (Vienna 2009) at 73, n. 91.

${ }^{491}$ See generally President Barack Obama, Weekly Address: President Obama Urges Action on Financial Reform (Mar. 20, 2010), available at http://www.whitehouse.gov/the-press-office/weekly-address-president-obama-urgesaction-financial-reform (President Obama describes reform legislation working its way through Congress and urges its passage. The legislation would provide new oversights for complicated financial products, prohibit banks from engaging in risky transactions with their own hedge funds, allow shareholders to have a say in executive compensation, offer new tools to disassemble failing financial firms in order to prevent them from becoming "too big to fail," and create a new federal agency to prevent predatory loans.); French President Nicolas Sarkozy, Opening Address of the World Economic Forum Annual Meeting 2010 (Jan. 27, 2010), available at http://www.weforum.org/pdf/Sarkozy en.pdf (President Sarkozy decries the deregulation of the global financial market preceding the current global crisis. He calls for reclaiming capitalism's "moral dimension," and urges that
} 
calls, no new international regulatory agency or institution, no new hot line between national financial authorities, and no new treaty will prevent decisions driven by national politics from shaping the next financial crisis. In Iceland's case, Britain's invocation of its anti-terrorism laws to seize the Icelandic banks' assets in the U.K. short-circuited any chance that any of the Icelandic banks could have been saved. We will never know if they could, and the claims that Kaupthing might have been saved come largely from parties with an interest in the argument that the bank was done in by external forces. Moreover, only Alistair Darling knows for certain what he meant when he made his now infamous statement that Iceland had no intention of paying its debts. Nonetheless, the invocation of anti-terror finance legislation by one NATO member against another was an unprecedented and Darling's (and by extension, the British government's) attack on Iceland at the moment of Iceland's greatest weakness is also unprecedented among allies. The Brown government's motive in going on the offensive against the Icelandic banks was clearly driven by domestic political concerns - as the crisis began, the Labour government's poll numbers stood at $29 \%$, compared to the Conservatives' $44 \%$ and the Liberal Democrats' 19\%. ${ }^{492}$ By December 2008, poll results had shifted in Labour's favor, with the three parties at 33\%, 38\%, and 19\% respectively. ${ }^{493}$ Britain and the Netherland's willingness to play realpolitik in blocking IMF, Nordic, and EU efforts to assist Iceland also demonstrate the importance of purely domestic politics, since whether Iceland compensates Britain and the Netherlands for their compensation of depositors above the minimum guarantee provided by EU deposit insurance guidelines and the interest rate applicable to such a debt are irrelevant to any principle of international law. This same dynamic appears to be at work in the EU's deliberations over bailing out the Greek government, where Greek politicians are invoking World War II in an effort to push Germany to agree to a more generous bailout ${ }^{494}$ while German politicians hold firm because of the strong German popular opposition to bailing out Greece. ${ }^{495}$ Other histories are invoked in discussing the other European crises.

the world respond to "the demand for protection, justice and fairness through cooperation, regulation and governance." He asks for a coordinated regulatory effort amongst the world's nations, and he calls for a new Bretton Woods system in the 21 st century, a system whose rules and regulations helped to bring prosperity to the post-WWII era.).

${ }^{492}$ Guardian/ICM Poll Results, available at https://spreadsheets.google.com/ccc?key=phNtm3LmDZEO8F79tf8B0fg\#gid=0 (numbers for Aug. 17, 2008).

${ }^{493}$ Guardian/ICM Poll Results, supra note 492, (data for Dec. 14, 2008). See also Jeffrey Stinson, Perceptions of Brown Shift in Crisis; Some Give Credit; Others Lay Blame, USA TODAY, OCT. 21, 2008, at 5A (discussing how the economic crisis of October 2008 gave Gordon Brown a chance to have a "Churchillian moment," and detailing how in late August 2008 Brown's Labor Party trailed the Conservatives 25\% to 46\% and, in the same poll, on October 19, 2008 they trailed only $31 \%$ to $40 \%$ ).

${ }^{494}$ See, e.g., Vanessa Fuhrmans, World News: Greece-Germany Tensions Rise Amid a War of Words, WALL ST. J., Feb. 25, 2010, at A9 (reporting on Greek Deputy Prime Minister Theodoros Pangalos' criticisms of Germany's demand for Greek austerity measures as a condition of the bailout and his claims that Germany never paid adequate reparations for the Nazi's invasion and occupation of Greece).

495 See Stephen Castle, Germany Seems to Signal A Compromise on Greece, NY TIMES, Mar. 24, 2010, § B, at 4 (stating that German chancellor Angela Merkel faces "strong public opposition" to a bailout for Greece); Vanessa Fuhrmans, World News: German Exports Spark a Debate, WALl ST. J., Mar. 16, 2010, at A18 (reporting on polls showing a "vast majority" of Germans opposed to a bailout for Greece); Fuhrmans, supra note 443 (citing polls showing nearly two-thirds of Germans "staunchly opposed to participating in a Greek bailout"). 
A realistic assessment of future international financial regulatory efforts must therefore take into account that merely establishing an international agency (the IMF), supranational financial institutions (the ECB), or even broad parameters of cooperation between nations (the NATO treaty, the EEA association with the EU) is insufficient to prevent national politicians concerned with domestic political issues from trumping the international framework, issues, or interests with politically-based domestic concerns. Recognizing that politics will trump principle in a time of crisis suggests that regulatory programs not rely on politicians "doing the right thing" when the chips are down. Avoiding placing discretionary decisions in the political arena and relying as heavily as possible on market pressures to push corrective actions makes regulatory regimes more robust.

\section{IV.Conclusion}

As we noted at the start, the Icelandic story has been told primarily as a tale of hubris or as a cautionary warning against deregulation. Perhaps Iceland was too small to have a financial sector; Boyes quotes an Icelandic economist as saying the crash was caused by "a mere thirty people" among the decision making elite. ${ }^{496}$ Perhaps Iceland was too complex a society to be readily grasped by outsiders. Boyes summarizes an account of one Icelandic businessman's dealings by stating that "[u]nderstanding Icelandic capitalism was akin to listening for the underlying themes flowing through the Wagnerian Ring cycle." ${ }^{\text {"97 }}$ Perhaps Icelanders were too inexperienced. ${ }^{498}$ Perhaps they were "driven by an almost deranged desire to be taken seriously by the world." 499 Perhaps they "grew up ... with ambitions that bore no relation to what might be realistically achievable from a tiny, remote Arctic island." ${ }^{, 500}$ Perhaps all of these are true in some respects. But it is equally true that the "inexperienced" Icelandic financial sector learned the same way lawyers, financiers, and others have learned about financial transactions for decades by engaging in transactions, asking questions, and copying methodologies. ${ }^{501}$

How the story of the Icelandic financial crisis enters our discourse matters because ignoring the issues we have raised ensures that the next crisis - whether in Washington, London or Athens - will be more harmful than it would be if these issues were addressed. It matters because it also means it is more likely that there will be another crisis - since ignoring the interaction between fiscal and monetary policy and financial regulation makes financial regulation less effective. We have no prepackaged "solution" or new "paradigm" to offer. The ultimate lesson of Iceland is the need for humility in financial regulation, in defining the expectations we have for what regulators can do, and in international mechanisms for cooperation.

\footnotetext{
${ }^{496}$ Boyes, supra note 4 , at 7.

${ }^{497}$ Boyes, supra note 4 , at 69.

${ }^{498}$ Boyes, supra note 4, at 87 (describing new recruits into banking as "[i]nexperienced, entranced [by their salaries and jobs] ... blissfully unaware of their inexperience and entrancement.”).

${ }^{499}$ Boyes, supra note 4, at 95.

500 Thorvaldsson, supra note 43 , at 58.

${ }^{501}$ See, e.g., Thorvaldsson, supra note 43, at 26-27, 67, 85 (describing how Kaupthing executives asked questions of partners on deals, including a 17 page letter asking for definitions of basic terms, copied Deutsche Bank templates and methods to create better quality proposals, and learned by doing in transactions, getting experience as well as fees from transactions).
} 
In the late 1960s, economists working in energy identified a phenomenon they named the "winner's curse." ${ }^{, 502}$ In a winner's curse situation, the winning bidder in an auction proves to be consistently over- optimistic about the value of the item being auctioned. Where the bidders are ignorant of the true value of the item, the winner comes from the far right tail of the distribution of randomly distributed beliefs about the value and so bids above the expected value of the item. ${ }^{503}$ Winners thus found themselves "cursed" with a resource worth less than they paid. ${ }^{504}$ Finding that this accurately described bidding over offshore oil leases, as the then current level of knowledge did not enable reasonable estimation of leases' value in advance of drilling, the economists published an academic paper explaining the problem in hopes of persuading bidders to moderate their bids under such conditions. ${ }^{505}$ In the same spirit, we have written this Article in part because we hope it persuades those busy reconfiguring global financial regulation to be more modest in their aims and methods.

The financial crisis has caused extraordinary hardship for the people of Iceland and for depositors in financial institutions outside Iceland that had some connection to Iceland. We have considerable sympathy for everyone involved (except Gordon Brown and Alistair Darling, who really should have known better). Having sympathy ought not to translate into "doing something", however. In 1887, U.S. President Grover Cleveland vetoed a bill intended to provide relief for farmers in Texas suffering from a drought. In doing so, he wrote

I do not believe that the power and duty of the general government ought to be extended to the relief of individual suffering which is in no manner properly related to the public service or benefit. A prevalent tendency to disregard the limited mission of this power and duty should, I think, be steadfastly resisted, to the end that the lesson should be constantly enforced that, though the people support the government, the government should not support the people. ${ }^{506}$

A similar sentiment ought to apply to the fallout from the Icelandic crisis and the other European crises as well. Individuals in Iceland and elsewhere lost money (sometimes a great deal of money) when the Icelandic banks collapsed. Similar losses are being incurred in Ireland, Greece, Portugal, and Spain. Those individuals all had contracts, some of which included clauses providing a means to address problems and some of which did not. Indeed, the global financial crisis exposed a general problem in many investment contracts, which inadequately addressed problems ranging from counter-party risk to liquidation during periods of illiquidity. ${ }^{507}$ Future

\footnotetext{
502 Richard Thaler, Anomalies: The Winner's Curse, 2 J. ECON. PERSPECTIVES 191, 192 (1988). See also Richard Thaler, THE WINNER's CURSE: PARADOXES AND ANOMALIES OF ECONOMIC LIFE (1994).

503 Thaler, Anomalies, supra note 502, at 192.

504 Thaler, Anomalies, supra note 502, at 192.

505 Thaler, Anomalies, supra note 502, at 201. The article originally documenting the problem was E.C. Capen, R. V. Clapp, and W.M. Campbell, Competitive Bidding in High-Risk Situations, 23 J. Petroleum TeCH. 641 (1971).

${ }^{506}$ Congressional Record, 49 Cong., 2d Sess., vol. XVIII, Pt. II, 1887, p. 1875. Not relevant to our point here is that Cleveland also believed the bill went beyond the federal government's constitutional authority. Id.

${ }^{507}$ See George M. Cohen, The Financial Crisis and the Forgotten Law of Contracts, University of Virginia Law and Economics Working Paper No. 2011-09 (Sept. 2011) (SSRN 926753); Franklin Allen \& Elena Carletti, The Role of Liquidity in Financial Crises, Sept. 14, 2008 available at http://www.kc.frb.org/publicat/sympos/2008/AllenandCarletti.09.14.08.pdf (liquidity issues); Philippe Jorion \&
} 
contracts will likely be different as a result. Dealing with gaps in previous contracts is something contract law has been doing since at least Roman times. ${ }^{508}$ That process (which one of us is earning a living participating in now) offers an orderly means of addressing competing claims, one which we believe is superior to the political process initiated by Britain and the Netherlands in their efforts to shift losses away from British and Dutch voters and onto Icelandic taxpayers.

Our approach may appear cold hearted. Grover Cleveland addressed that concern in his 1887 veto message and his thoughts apply as well to the international context:

The friendliness and charity of our countrymen can always be relied upon to relieve their fellow-citizens in misfortune. This has been repeatedly and quite lately demonstrated. Federal aid in such cases encourages the expectation of paternal care on the part of the government and weakens the sturdiness of our national character, while it prevents the indulgence among our people of that kindly sentiment and conduct which strengthens the bonds of a common brotherhood. ${ }^{509}$

Indeed, that sentiment has already been demonstrated in the response to the Haitian earthquake, when a team from nearly-broke Iceland joined teams from the U.K. and the Netherlands and others in addressing needs greater than their own. ${ }^{510}$ Just as President Cleveland correctly saw that not every humanitarian crisis required a federal statute, so we contend that not every financial crisis requires an international regulatory agency or increase in regulation.

Gaiyan Zhang, Credit Contagion from Counterparty Risk, (Dec. 2008) available at http://papers.ssrn.com/sol3/papers.cfm?abstract_id=1321670.

${ }^{508}$ See Richard A. Epstein, The Roman Law of Cyberconversion, 2005 MICH. ST. L. REV. 103, 120 (2005) (“the issues that we have here [in modern case] involve the allocation of the risk of loss in a broken-down transaction. The differential treatment of stranger and contractual transactions is as old as the law itself, and it continues to maintain its vitality in newer areas."); Cohen, supra note 507.

${ }^{509}$ Congressional Record, 49 Cong., 2d Sess., vol. XVIII, Pt. II, 1887, p. 1875.

${ }^{510}$ Iceland sends earthquake help to Haiti, ICENEWs (13 Jan. 2010) available at http://www.icenews.is/index.php/2010/01/13/iceland-sends-earthquake-help-to-haiti/; Habitat for Humanity Netherlands, http://www.habitat.org/intl/eca/142.aspx?print=true (describing Haiti project); UK agencies to help in Haiti earthquake rescue, BBC News (Jan. 13, 2010) available at http://news.bbc.co.uk/2/hi/8456252.stm (describing volunteer responses). 